\title{
ROCK-EVAL PYROLYSIS, VITRINITE REFLECTANCE, AND KEROGEN MICROSCOPY RESULTS FROM MIOCENE CARBONACEOUS MUDSTONES AND COALS IN OUTCROP, McGRATH QUADRANGLE, SOUTHWESTERN ALASKA
}

David L. LePain and Russell A. Kirkham

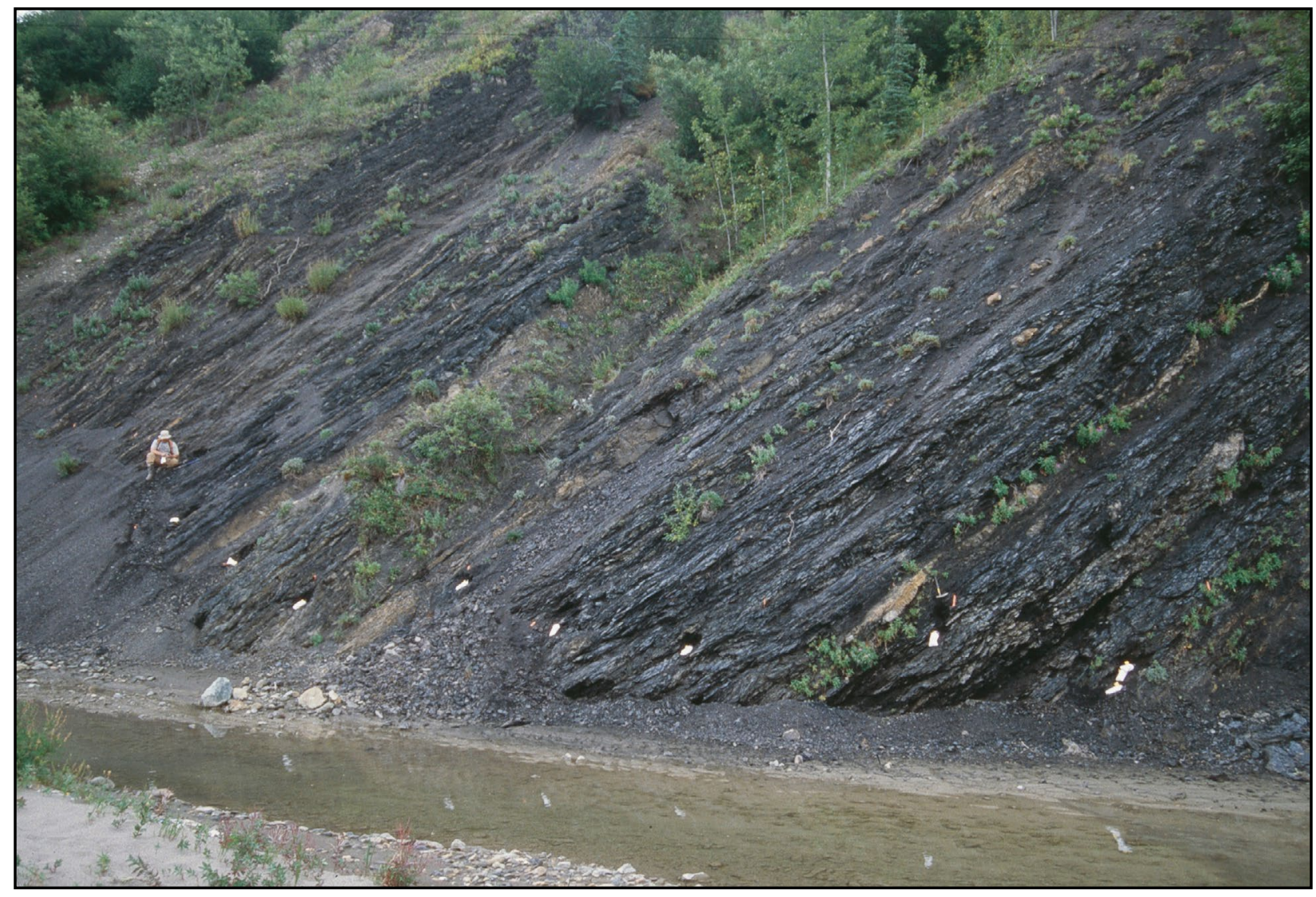

Exposure of early Miocene carbonaceous mudstone and coal along Windy Fork (of Middle Fork of Kuskokwim River), McGrath Quadrangle. These rocks belong to Dickey's (1982) map unit Tqa, which corresponds to a fault-bounded package of Tertiary sedimentary rocks along the Denali-Farewell fault zone. The photograph shows the 40-56 $\mathrm{m}$ interval in measured section 02DL053 (see figure 3 in this report). The white objects visible in the photograph near the base of the exposure are Rock-Eval samples. Geologist is sitting at the $52 \mathrm{~m}$ level in the section. Photo by D.L. LePain.

\section{Published by}

STATE OF ALASKA

DEPARTMENT OF NATURAL RESOURCES

DIVISION OF GEOLOGICAL \& GEOPHYSICAL SURVEYS 
ROCK-EVAL PYROLYSIS, VITRINITE REFLECTANCE, AND

KEROGEN MICROSCOPY RESULTS FROM MIOCENE CARBONACEOUS

MUDSTONES AND COALS IN OUTCROP, MCGRATH QUADRANGLE, SOUTHWESTERN ALASKA

David L. LePain and Russell A. Kirkham

Report of Investigations 2015-3

State of Alaska

Department of Natural Resources

Division of Geological \& Geophysical Surveys 


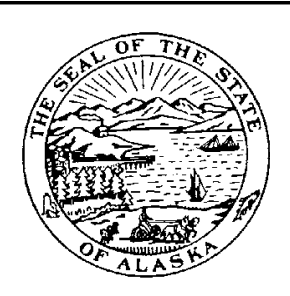

\section{STATE OF ALASKA}

Bill Walker, Governor

\section{DEPARTMENT OF NATURAL RESOURCES}

Mark Myers, Ph.D., Commissioner

\section{DIVISION OF GEOLOGICAL \& GEOPHYSICAL SURVEYS}

Steve Masterman, State Geologist and Director

Publications produced by the Division of Geological \& Geophysical Surveys (DGGS) are available for free download from the DGGS website (www.dggs.alaska.gov). Publications on hard-copy or digital media can be examined or purchased in the Fairbanks office:

\section{Alaska Division of Geological \& Geophysical Surveys 3354 College Rd., Fairbanks, Alaska 99709-3707 \\ Phone: (907) 451-5020 Fax (907) 451-5050 \\ dggspubs@alaska.gov www.dggs.alaska.gov}

\section{Alaska State Library}

State Office Building, 8th Floor 333 Willoughby Avenue

Juneau, Alaska 99811-0571

Elmer E. Rasmuson Library University of Alaska Fairbanks Fairbanks, Alaska 99775-1005
Alaska Resource Library \& Information Services (ARLIS)

3150 C Street, Suite 100

Anchorage, Alaska 99503-3982

University of Alaska Anchorage Library 3211 Providence Drive Anchorage, Alaska 99508-4614 


\section{CONTENTS}

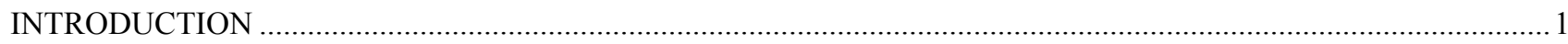

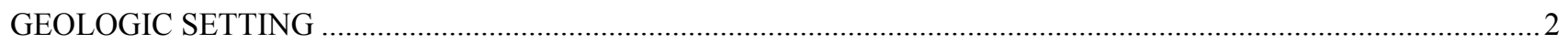

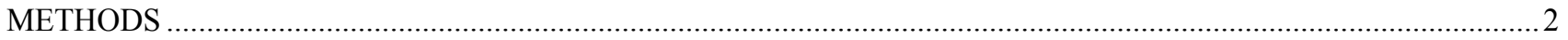

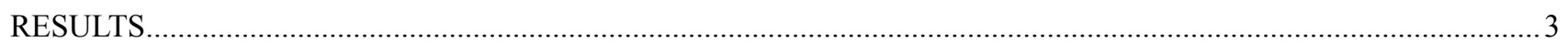

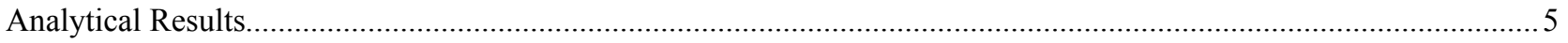

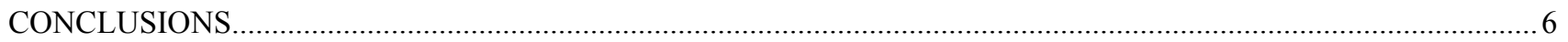

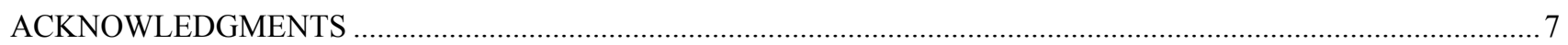

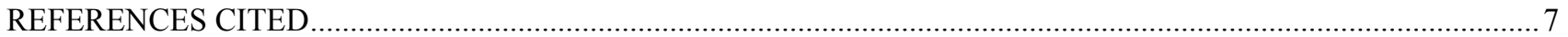

\section{FIGURES}

Figure 1. Simplified geologic map of the Holitna region in southwestern Alaska...................................................... 1

2. Portion of the McGrath B-3 Quadrangle, showing the location of the base of the measured stratigraphic

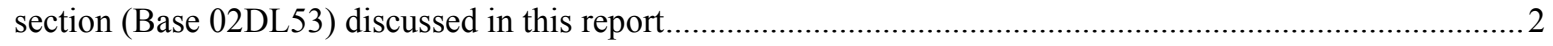

3. Measured stratigraphic section 02DL53 through part of a thick, coal-bearing mudstone succession exposed along the west bank of the Windy Fork of the Kuskokwim River .........................................................

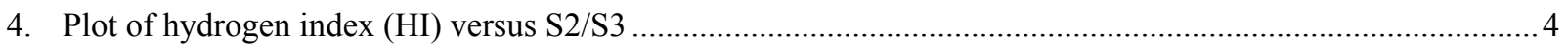

\section{TABLES}

Table 1. Summary of mean vitrinite reflectance, total organic carbon (TOC), and Rock-Eval pyrolysis data from outcrop samples collected from Miocene coal-bearing strata along the Middle and Windy Forks of the Kuskokwim River, McGrath B-3 Quadrangle, Alaska 


\title{
ROCK-EVAL PYROLYSIS, VITRINITE REFLECTANCE, AND KEROGEN MICROSCOPY RESULTS FROM MIOCENE CARBONACEOUS MUDSTONES AND COALS IN OUTCROP, MCGRATH QUADRANGLE, SOUTHWESTERN ALASKA
}

\author{
David L. LePain ${ }^{1}$ and Russell A. Kirkham ${ }^{2}$
}

\section{INTRODUCTION}

The Cenozoic Holitna basin is a gravity-defined feature that sits astride the Denali-Farewell fault zone in southwestern Alaska (fig. 1). The basin corresponds to a gravity low in excess of -40 milligals (mGals) (Kirschner, 1994; Meyer and Krouskop, 1984). No outcrops exist within the footprint of the gravity low and no subsurface data are available; consequently, the stratigraphy and age of its fill are unknown. The Alaska Division of Geological \& Geophysical Surveys (DGGS) investigated the shallow gas potential of the basin during the summer of 2000 by studying Tertiary coal-bearing rocks exposed along the Denali-Farewell fault zone to the northeast of the basin in the southern McGrath Quadrangle as an outcrop analog to the subsurface stratigraphy of the basin (LePain and others, 2003). This initial work included a limited suite of samples collected from carbonaceous mudstones and high-ash coals for Rock-Eval pyrolysis and, not surprisingly, the results suggest they were potential source rocks for gas. Results for two samples in this suite, collected along the Middle Fork of the Kuskokwim River, indicate the potential to generate liquid hydrocarbons. Three samples were collected for the same purpose from carbonaceous claystones near the top of a long exposure along the west bank of the Windy Fork of the Middle Fork (Kuskokwim River), and are thought to be correlative to the section sampled along the Middle Fork. Results for two of the samples indicate moderate potential as gas source rocks. The third sample contained very little organic material and results indicate poor gas source-rock potential.

Results for samples collected during the 2000 field season raise two fundamental questions. (1) Are carbonaceous

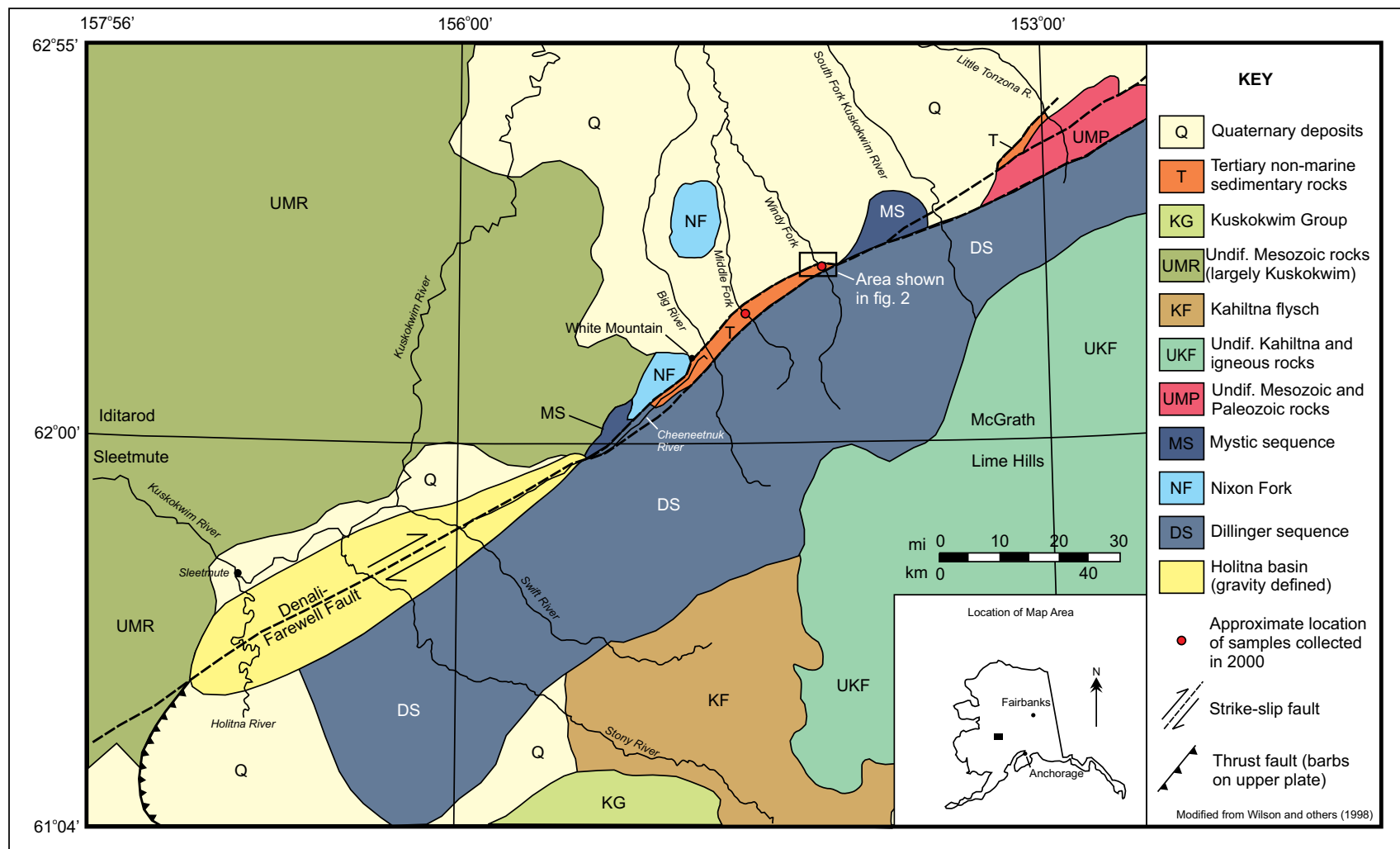

Figure 1. Simplified geologic map of the Holitna region in southwestern Alaska. The gravity-defined Holitna basin is the yellow tear-drop-shaped feature straddling the Denali-Farewell fault. Modified from Wilson and others (1998).

\footnotetext{
${ }^{1}$ Alaska Division of Geological \& Geophysical Surveys, 3354 College Road, Fairbanks, AK 99709-3707, david.lepain@alaska.gov

${ }^{2}$ Alaska Division of Mining, Land, and Water, $550 \mathrm{~W} 7^{\text {th }}$ Ave., Suite 900, Anchorage, AK 99501, russell.kirkham@alaska.gov
} 
mudstones and coals capable of generating liquid hydrocarbons common in the Middle Fork and Windy Fork exposures? (2) What is the hydrocarbon potential of coals from these outcrops? Only a few high-ash coals were sampled in 2000 for Rock-Eval pyrolysis, so the hydrocarbon source-rock characteristics of low-ash coals in these exposures were unknown. To help answer these questions, in 2002 we revisited the same exposures along Middle Fork and Windy Fork to collect additional samples for source-rock characterization, including Rock-Eval pyrolysis, vitrinite reflectance measurements, and visual kerogen analysis (figs. 1 and 2). During the 2002 field season the Middle Fork exposure was inaccessible due to changes in the location of the active stream channel, while the north end of the Windy Fork exposure was relatively well exposed and easily accessible (locality 02DL53 on fig. 2). For these reasons a stratigraphic section was measured at locality 02DL53 and an extensive suite of samples suitable for Rock-Eval pyrolysis were collected from mudstones, carbonaceous mudstones, and coals (fig. 3, on sheet). Grab samples for Rock-Eval were collected south of locality 02DL53, a short distance north of the mapped trace of the Farewell fault, at locality 02DL54 (fig. 2). This report summarizes the results of the 2002 dataset.

\section{GEOLOGIC SETTING}

Discontinuous exposures of Tertiary nonmarine sedimentary rocks are present northeast of the gravity-defined Holitna basin in fault-bounded slivers associated with the Denali-Farewell fault zone (fig. 1; Bundtzen and others, 1997; Dickey, 1982; Gilbert and others, 1982). Exposures extend from the White Mountains area northeastward to the
Little Tonzona River (fig. 1) and consist of thick packages of conglomerate, sandstone, and mudstone (Dickey, 1982, 1984; LePain and others, 2003; Ridgway and others, 2000).

Dickey (1982) recognized three Tertiary map units, of which only unit Tqa includes appreciable fine-grained rocks and coal. Dickey (1982) measured a thickness of 1,700 m and $650 \mathrm{~m}$ along Windy Fork and Middle Fork, respectively, in his map unit Tqa, and noted it included conglomerate, sandstone, siltstone, shale, carbonaceous shale, and coal. He was unable to measure a complete section through this unit due to structural complications, but noted the exposures had an overall fining-upward trend and were capped by a thick succession of coal-bearing siltstones and shales. DGGS's work in 2000 and 2002 focused on Dickey's (1982) map unit Tqa. Solie and Dickey (1982) classified the coals in the Windy Fork section as subbituminous A to high volatile $\mathrm{C}$ bituminous using vitrinite reflectance data. Coal-bearing strata are absent in outcrop between the Big River and White Mountain, and coal was seen only in float along the Cheeneetnuk River (LePain and others, 2003). The age of unit Tqa is early to middle Miocene on the basis of plant fossils, including megafossils and palynomorphs (LePain and others, 2003). These rocks were deposited in a basin, or basins, associated with the Denali-Farewell fault system (Ridgway and others, 2000).

\section{METHODS}

Forty-two samples were collected from exposures along Windy Fork. A northeast-trending syncline was mapped by Dickey (1982) along Windy Fork in his map unit Tqa. A thick succession of mudstone, carbonaceous mudstone, coal, and

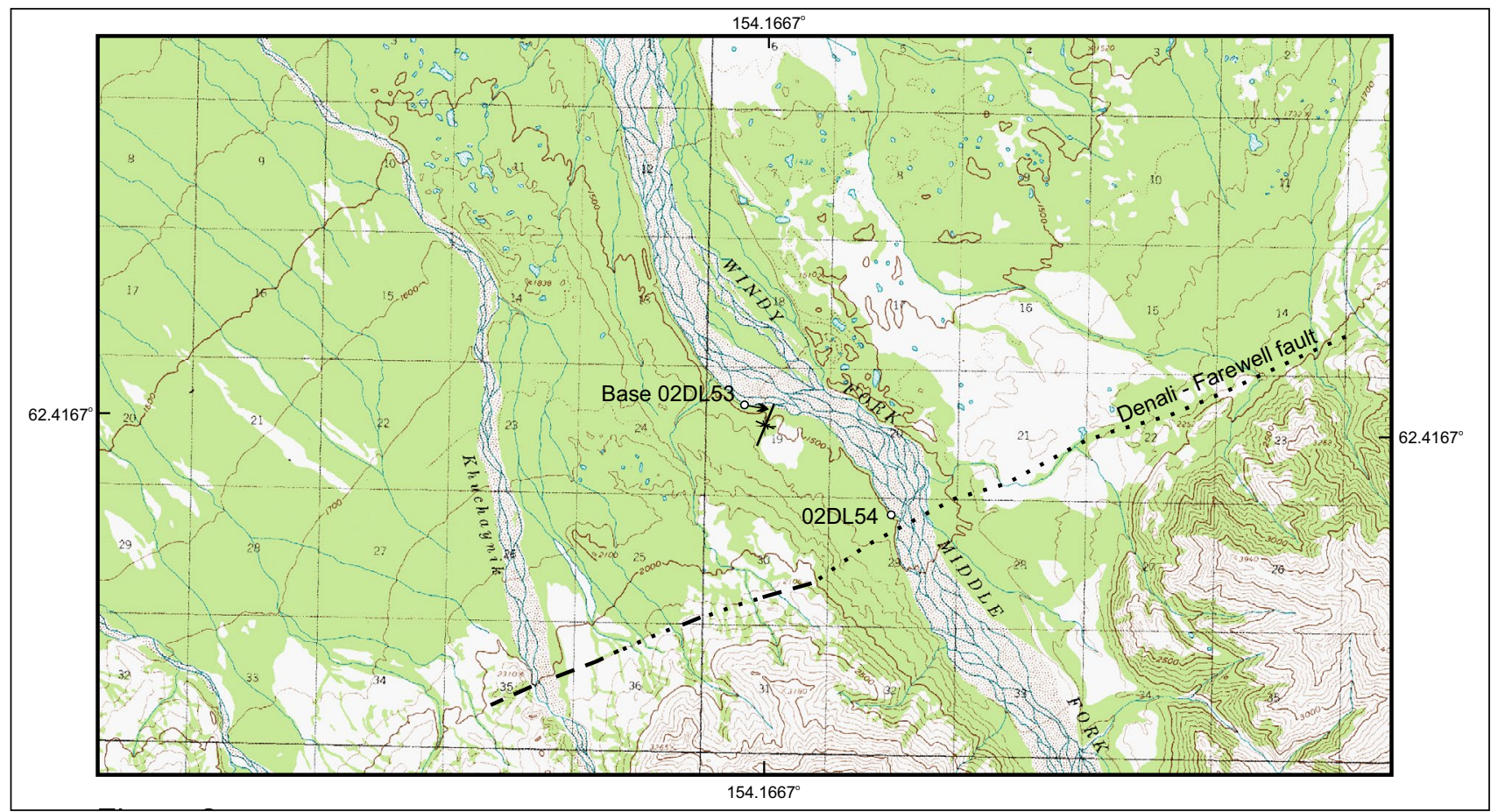

Figure 2. Portion of the McGrath B-3 Quadrangle, showing the location of the base of the measured stratigraphic section (Base 02DL53) and the location of grab samples (02DL54) discussed in this report. The trace of the Farewell fault and synclinal axis shown on this map are from Gilbert and others (1982). 
minor sandstone was well exposed in 2002 on the northwest limb of this structure. The succession on the southeast limb of the syncline was poorly exposed. Thirty-seven samples for organic geochemical analysis were collected from a 92-m-thick measured section (locality 02DL53) on the northwest limb of the syncline, near the stratigraphic top of the Windy Fork exposure of map unit Tqa (figs. 2 and 3). A Garmin handheld GPS unit (datum NAD27 Alaska) was used to determine the latitude and longitude of the base of the section and the section was measured using a Jacob staff. All sample locations associated with our measured section are relative to the coordinates of the base of the section and the position in the section measured in meters above the base in the dip direction. Southeast of the syncline, a short distance north of the mapped trace of the Farewell fault (Gilbert, 1982), five grab samples for organic geochemical analyses were collected from a recessive weathering succession between two thick sandstone bodies (locality 02DL54), including three from carbonaceous mudstone and one each from mudstone and coal (fig. 2). This locality is also in Dickey's unit Tqa, but in a succession with abundant interbedded sandstone and conglomerate. All samples were submitted to Baseline-DGSI in The Woodlands, TX, for Rock-Eval pyrolysis and measurement of total organic carbon (TOC). The same laboratory analyzed splits of 19 samples for visual kerogen and vitrinite reflectance (percent $\mathrm{R}_{\mathrm{o}}$ ). Solvent extract and whole extract chromatography was done on splits from eight of the samples. A report submitted to DGGS from the laboratory includes a brief summary of the analytical methods used and an interpretive summary of the sample results by Dr. Wallace G. Dow. This report is included in the appendix.

Rock-Eval data are used to assess the generative potential and thermal maturity of rocks (Peters, 1986). The following description of the method is taken from Peters (1986), Peters and Cassa (1994), and Dow (appendix of this report). The technique requires approximately $100 \mathrm{mg}$ of sample material, which is heated in a pyrolysis crucible attached to a flame ionization detector. The method provides several measurements, including $\mathrm{S} 1, \mathrm{~S} 2, \mathrm{~S} 3$, and $\mathrm{T}_{\max } . \mathrm{S} 1$, reported in $\mathrm{mg} / \mathrm{g}$ rock, measures the amount of hydrocarbons volatilized from the sample by heating to $300^{\circ} \mathrm{C}$ and represents the hydrocarbons in the sample at the start of the procedurethat is, hydrocarbons that have already been generated. S2, reported in $\mathrm{mg} / \mathrm{g}$ rock, measures the hydrocarbons generated by pyrolytic degradation of kerogen (cracking) by heating from $300^{\circ} \mathrm{C}$ to $550^{\circ} \mathrm{C}$ in $25^{\circ} \mathrm{C}$ per minute increments. S2 represents the generative potential remaining in the sample. S3 measures the carbon dioxide generated during S2 heating up to $390^{\circ} \mathrm{C}$ and is reported in $m g \mathrm{CO}_{2} / \mathrm{g}$ rock. $\mathrm{T}_{\max }$ is an indicator of thermal maturity and corresponds to the temperature of maximum S2 generation. When combined with TOC measurements, $\mathrm{S} 2$ and $\mathrm{S} 3$ are used to calculate the hydrogen and oxygen indices, respectively $(\mathrm{HI}=\mathrm{S} 2 / \mathrm{TOC}$ and $\mathrm{OI}=\mathrm{S} 3 / \mathrm{TOC}$ ). The $\mathrm{HI}$ and $\mathrm{OI}$ are typically plotted on a modified van Krevelen diagram and used to indicate the type of kerogen present in a sample (Type 1 - highly oil-prone, Type 2 - oil-prone, and Type 3 - gas-prone; Peters, 1986). TOC, mean vitrinite reflectance, and Rock-Eval results are summarized in table 1.

We use Potter and others' (2005) terminology for finegrained sedimentary rocks and in this report we use TOC in weight percent to help classify sample lithology. Samples with TOC values 50 weight percent or greater are classified as coal; samples with TOC values greater than or equal to 2 weight percent and less than 50 weight percent are classified as carbonaceous mudstones; and samples with less than 2 weight percent organic carbon are classified as mudstones. The high TOC content in many of our carbonaceous mudstone samples is likely due to the fact that most sample locations included thinly interbedded organic-rich mudstone and stringers of coal.

\section{RESULTS}

\section{MEASURED SECTION}

The stratigraphic section measured along the west side of Windy Fork at locality 02DL53 (figs. 2 and 3) consists of a 92-m-thick succession of interbedded carbonaceous claystone, carbonaceous siltstone, siltstone, coal, and minor fine-grained sandstone. This section is located at the top of a thick succession of dominantly sandstone and conglomerate (Dickey, 1982). Most claystone and carbonaceous siltstone is dark gray to nearly black weathering. Coal is present as seams up to $4 \mathrm{~m}$ thick and as thin, discontinuous stringers ranging from $0.1 \mathrm{~cm}$ to several centimeters thick, and includes alternating dull and bright bands, each a few millimeters thick. Megascopic plant material is very abundant throughout the section and includes variably preserved broad-leaf fossils and coalified woody branch material and logs. Brown, orange-brown and orange mottling are present locally and rhizoliths are abundant in siltstones and sandstones. Carbonaceous lithologies display thin parting character (few millimeters to centimeters thick), which may correspond to bedding. Bedding in siltstones and sandstones ranges from a few centimeters to a few decimeters thick and bounding surfaces are typically wavy and non-parallel. Small-scale trough cross-bedding is present locally but most sandstones and siltstones appear structureless.

The features described in the previous paragraph are consistent with deposition in a poorly drained overbank setting located away from active fluvial channel tracts. Thinly interbedded carbonaceous claystone and coal stringers appear undisturbed and are interpreted as lacustrine deposits. The thinner sandstone beds are interpreted as splay sheet sands (sand at $71.4 \mathrm{~m}$ ), whereas the thicker bed sets could represent channel levees or crevasse splay sand bodies (sand body from $2.8 \mathrm{~m}$ to $5.6 \mathrm{~m}$ and at top of measured section). Brown, orange-brown and orange mottling and rhizoliths indicate the depositional surface was locally elevated above standing water level and was modified by vegetation and soil development. 


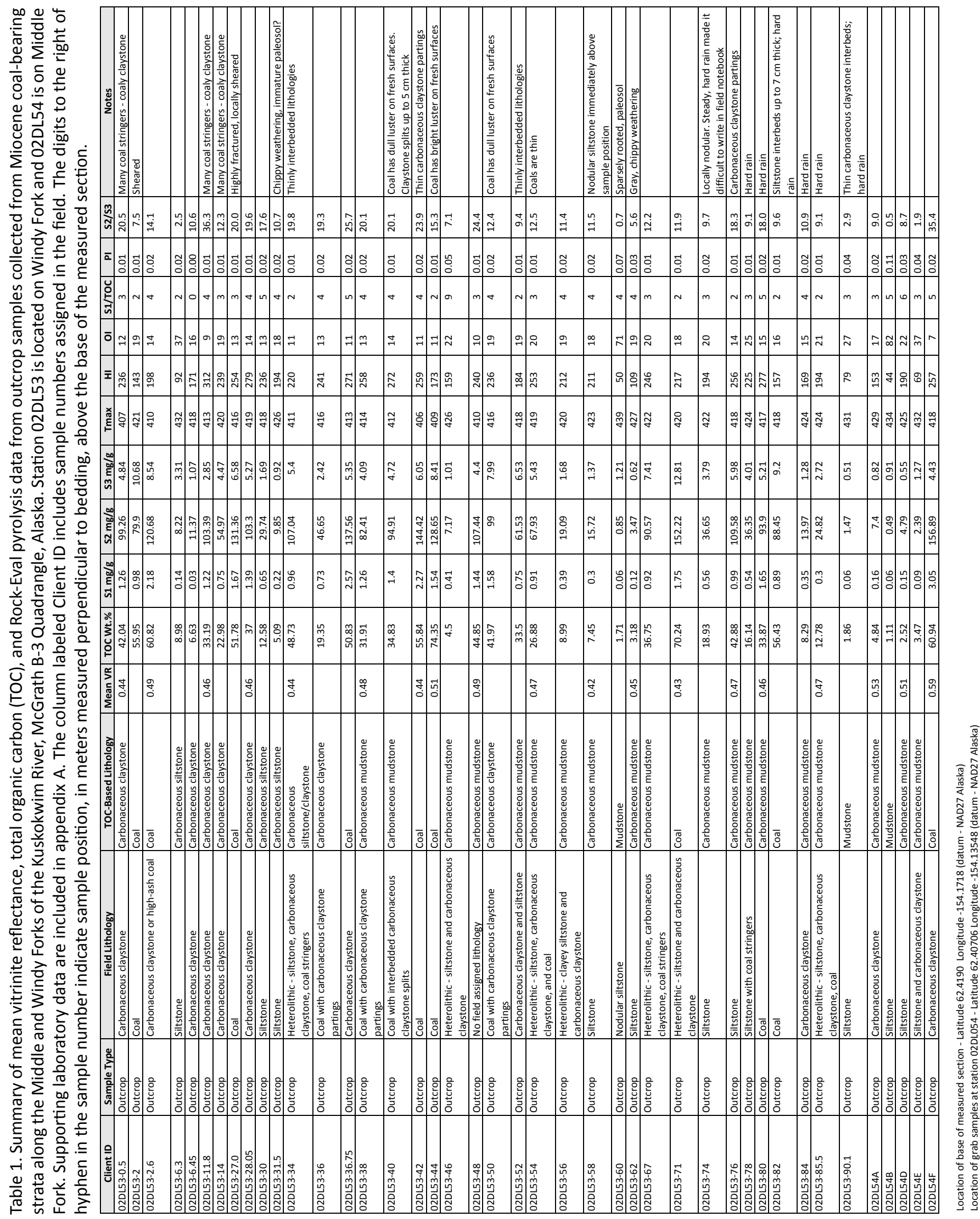




\section{ANALYTICAL RESULTS}

Total organic carbon (TOC) and hydrogen index (HI) are measures of the amount of organic carbon in a rock and the fraction of that carbon that is convertible to hydrocarbons by pyrolysis (Peters, 1986). This information provides a general indication of a rock's hydrocarbon-generating potential under favorable subsurface conditions. The TOC values for the samples collected from the Windy Fork measured section range from 1.71 to 74.3 percent and the TOC values in grab samples from the southeast end of the Windy Fork exposure range from 1.11 to 60.94 weight percent. As noted previously, coal typically has a TOC value equal to or greater than 50 weight percent. For most samples, the TOC results are consistent with the lithology assigned to the sample when it was collected in the field.

The vitrinite reflectance and $T_{\max }$ values indicate that samples from both locations are immature with respect to the onset of hydrocarbon generation, with the exception of sample 02DL53-60 which has a $T_{\max }$ of 439. Vitrinite reflectance and $T_{\max }$ values of 0.6 percent $R_{o}$ and greater than 435 , respectively, mark the onset of oil generation. Mean vitrinite reflectance of the samples from our Windy Fork measured section range from 0.42 to 0.51 percent $R_{0}$, with a mean value (mean of the mean) of 0.46 percent $R_{0}$. The mean vitrinite reflectance of grab samples from the Windy Fork exposure ranges from 0.51 to 0.59 percent $R_{0}$, with a mean value of 0.54 percent $R_{0}$. $T_{\max }$ ranges from 406 to 439 for the Windy Fork measured section samples and 418 to 434 for the Windy Fork grab samples. Kerogen microscopy on splits of 19 samples indicate that most contain very high percentages of lipid-rich (fluorescent) vitrinite and only minor amounts of structured and unstructured lipid material (see laboratory report in appendix). Dow states that our samples are in the late pre-oil generation stage (see appendix a).

$\mathrm{S} 1$ and S2 results are consistent with the thermal maturity of the samples. Low S1 values indicate that few to no hydrocarbons were present in the samples at the start of the Rock-Eval analysis, which is to be expected for thermally immature rocks. S2 results indicate that significant volumes of organic carbon were converted to hydrocarbons by pyrolysis. The $\mathrm{S} 2$ yield ranges from about $55 \mathrm{mg} / \mathrm{g}$ to $157 \mathrm{mg} / \mathrm{g}$ for coals (mean S2 $=105 \mathrm{mg} / \mathrm{g}$ ), from about $2 \mathrm{mg} / \mathrm{g}$ to $47 \mathrm{mg} / \mathrm{g}$ for carbonaceous mudstones (mean S2 $=17 \mathrm{mg} / \mathrm{g}$ ), and 0.5 $\mathrm{mg} / \mathrm{g}$ to $1.5 \mathrm{mg} / \mathrm{g}$ for siltstones (mean $\mathrm{S} 2=1 \mathrm{mg} / \mathrm{g}$ ). Based on criteria outlined in Peters and Cassa (1994, table 5.1), the $\mathrm{S} 2$ yields suggest that our coal samples and most of our carbonaceous mudstone samples have excellent hydrocarbon potential, and that our siltstone samples have poor petroleum potential. Figure 4 is a plot of hydrogen index (HI) versus S2/ S3. Samples with HI values between 50 and 200 correspond to Type III kerogen that would be expected to expel mainly gas at peak maturity and those with $\mathrm{HI}$ values between 200 and 300 correspond to a mixture of Type II and III kerogen and would be expected to expel a mix of oil and gas at peak maturity (Peters and Cassa, 1994). Most of the coals and some carbonaceous mudstones in our sample suite plot in the "mixed oil and gas" field and some coals and most carbonaceous mudstones plot in the "gas" field on figure 4. One sample from the Windy Fork measured section (collected at $11.8 \mathrm{~m}$ above the base) has an $\mathrm{HI}$ greater than 300 and S2/S3

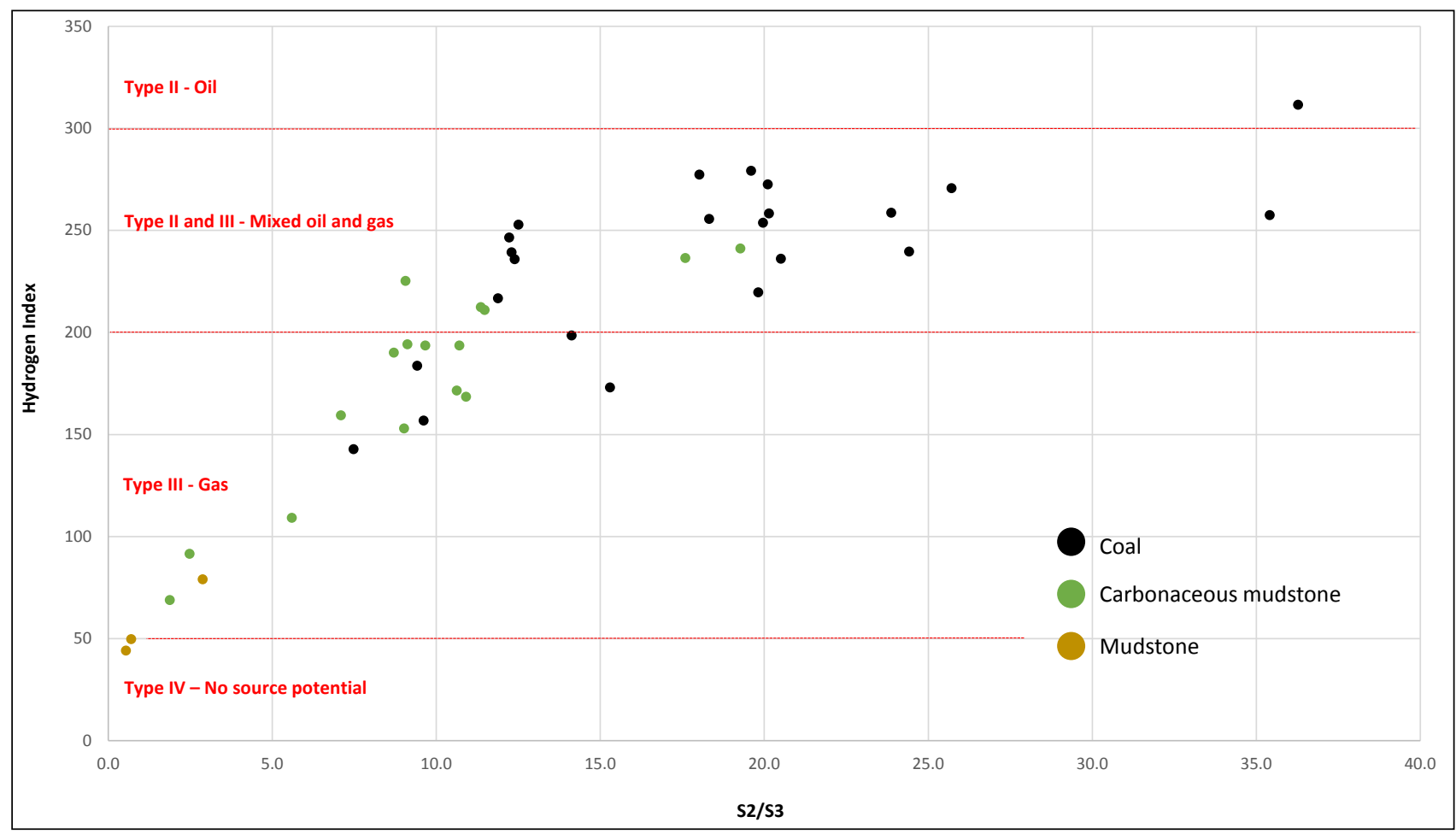

Figure 4. Plot of hydrogen index (HI) versus S2/S3. Rock-Eval pyrolysis data are summarized in table 1. Supporting laboratory data are included in appendix $A$. 
value greater than 35 , suggesting it is oil-prone. Low production index (PI) values, the ratio of generated hydrocarbons to potential hydrocarbons, $(\mathrm{PI}=\mathrm{S} 2 /(\mathrm{S} 1+\mathrm{S} 2)$; table 1$)$ are consistent with immature coals.

Assessing the liquid hydrocarbon generative potential of coals presents some challenges. Peters (1986) cautions that pyrolysis, for reasons not fully understood, tends to overestimate the liquid hydrocarbon potential of coaly rocks. Most of the samples in our suite are coaly, including many of the carbonaceous mudstones that commonly include thin, coaly stringers, so the liquid hydrocarbon potential may be less than suggested by the Rock-Eval results (table 1 and fig. 4). Stanley and others (2014) evaluated the petroleum potential of coals and carbonaceous mudstones in the Sheep Creek 1 well in the Susitna basin in south-central Alaska. Their results suggest that most of the coals in their suite contain mixed oil- and gas-prone kerogen. Sykes and Snowdon (2002) and Petersen (2006) demonstrate that coals have a unique characteristic in that the $\mathrm{HI}$ increases with increasing thermal maturity up to the threshold of oil expulsion and that proper evaluation of the petroleum potential of coals should account for this increase. Petersen (2006) states that the HI of immature humic coals should be adjusted upward by up to $90 \mathrm{mg}$ hydrocarbons/g rock. Shifting our coal samples by this amount would result in all of them plotting in the oilprone field on figure 4.

Another aspect of coals as source rocks is that they tend to act as a "sponge" for liquid hydrocarbons in that oil generated from them is stored initially in the coal matrix. Petersen (2006) states that the effective oil window for Cenozoic coals ranges from 0.85 to 2.0 percent $R_{o}$. At 0.85 percent $R_{o}$ the coal matrix is thought to be saturated with hydrocarbons, and continued oil generation results in oil expulsion.

Given that our samples were collected from outcrops, the organic material they contain has been altered by surfaceweathering processes. Stanley (1987) found that S2 values in weathered coals are lower than in fresh coals. Due to effects of weathering, the results presented in this report may underestimate the hydrocarbon generative potential of the sampled rocks. Despite Peters' (1986) cautionary statement regarding the tendency of Rock-Eval data to overestimate the liquid hydrocarbon potential of coaly rocks, in light of Petersen's (2006) work our sample results suggest that if a comparable carbonaceous mudstone- and coal-bearing succession is present in the subsurface of the Holitna basin at depths within the oil window, its liquid hydrocarbon potential may be greater than indicated by our data.

The depth to the top of the oil window in the Holitna basin can be calculated using an estimate of the temperature for the onset of effective oil generation in coaly rocks and the geothermal gradient. Petersen (2006) states that generation of liquid petroleum in humic coals is a complex, three-phase process that includes the onset of petroleum generation, petroleum build-up in the coal, and initial petroleum expulsion followed by efficient expulsion. He defines the effective oil window as the onset of liquid petroleum expulsion from coaly source materials and states that this corresponds to a vitrinite reflectance range of 0.85 to 1.05 percent $R_{o}$ and the termination of liquid petroleum generation corresponds to a vitrinite reflectance range of 1.5 to 2.0 percent $R_{0}$. For our calculation we assume the onset of liquid petroleum expulsion occurs at 0.85 percent $\mathrm{R}_{\mathrm{o}}$. Using the linear regression equation in Barker and Pawlewicz (1986) that relates mean vitrinite reflectance and maximum temperature $\left(\ln \left[\mathrm{R}_{\mathrm{o}}\right.\right.$ mean $]$ $=0.0096-1.4$ ) and using a mean vitrinite reflectance value to 0.85 percent $R_{o}$ yields a maximum temperature for the start of the effective oil window of $129^{\circ} \mathrm{C}$. Assuming a geothermal gradient of $25^{\circ} \mathrm{C} / \mathrm{km}$ in the gravity-defined Holitna basin and mean annual temperature at the surface of $0.0^{\circ} \mathrm{C}$, the depth to the top of the effective oil window is estimated to be $5.2 \mathrm{~km}$ $(17,056 \mathrm{ft})$. Assuming a geothermal gradient of $30^{\circ} \mathrm{C} / \mathrm{km}$, the depth to the top of the effective window is estimated to be 4.3 $\mathrm{km}(14,104 \mathrm{ft})$. The coal-bearing succession summarized in this report has experienced maximum temperatures ranging from $56^{\circ} \mathrm{C}$ to $91^{\circ} \mathrm{C}$. These temperatures indicate a maximum burial depth ranging from 1.9 to $3.6 \mathrm{~km}(6,100-11,808 \mathrm{ft})$. This calculation applies to a conventional liquid petroleum system in which hydrocarbons generated from coaly source rocks are expelled from the source material and migrate to a porous and permeable reservoir. As noted earlier, the Holitna basin is defined by a gravity low of -40 mGals, which Smith and others (1985) interpreted to represent a sedimentary succession up to $4.5 \mathrm{~km}(14,800 \mathrm{ft})$ thick. If their estimate is close to the true thickness of Cenozoic strata in the basin, it is possible that coal-bearing strata are present in the basin at depths in the oil window.

The onset of petroleum generation in most source rocks is generally agreed to occur at a vitrinite reflectance of 0.6 percent $R_{0}$. This correspond to a temperature of approximately $93^{\circ} \mathrm{C}$. Using the same range of geothermal gradients $\left(25^{\circ} \mathrm{C}\right.$ and $\left.30^{\circ} \mathrm{C}\right)$, the onset of liquid hydrocarbon generation would occur at depths of approximately $3.7 \mathrm{~km}(12,200 \mathrm{ft})$ and $3.1 \mathrm{~km}(10,200 \mathrm{ft})$, respectively. The depth range between the onset of liquid hydrocarbon generation and the onset of efficient expulsion (top of the effective oil window) can be regarded as the depth range where the coal and coaly mudstone function as both source and reservoir for generated hydrocarbons. Coals are mechanically weak and it is unclear if they have the requisite mechanical properties to serve as reservoir rocks at these depths.

\section{CONCLUSIONS}

Rock-Eval pyrolysis results from carbonaceous mudstone and coal samples along Windy Fork indicate the presence of Type II and Type III kerogen, which are expected to be excellent sources of oil and gas under favorable subsurface conditions. Available thermal maturity data for the samples indicate they are immature for oil and gas, but are in the late pre-oil phase of maturity.

If a coal- and carbonaceous-mudstone-bearing succession similar to the rocks discussed in this report from the McGrath Quadrangle are present in the subsurface of the gravity-defined Holitna basin at favorable depths, they can be expected to have significant thermogenic oil and gas generative potential. The depth in the basin to the top of the oil 
(and gas) window will depend on the geothermal gradient. In addition, if coal and carbonaceous mudstone are present in the subsurface they might serve as substrates for microbial generation of methane, as in Cook Inlet.

\section{ACKNOWLEDGMENTS}

The work summarized in this report was funded by the State of Alaska. We gratefully acknowledge Calista Corporation for their support of this work. We thank Rick Stanley for discussions regarding the petroleum source potential of coal and for reviewing a draft of this manuscript.

\section{REFERENCES CITED}

Barker, C.E., and Pawlewicz, M.J., 1986, The correlation of vitrinite reflectance with maximum temperature in humic organic matter, in Buntebarth, Guenter, and Stegena, Lajos, eds., Paleogeothermics - Evaluation of Geothermal Conditions in the Geological Past: Berlin-Heidelberg, Springer-Verlag, p. 79-93.

Bundtzen, T.K., Harris, E.E., and Gilbert, W.G., 1997, Geologic map of the eastern half of the McGrath Quadrangle, Alaska: Alaska Division of Geological \& Geophysical Surveys Report of Investigation 97-14A, 34 p., 1 sheet, scale 1:125,000. doi:10.14509/2549

Dickey, D.B., 1982, Tertiary sedimentary rocks and tectonic implications of the Farewell fault zone, McGrath Quadrangle, Alaska: Fairbanks, Alaska, University of Alaska, unpublished Master's thesis.

Dickey, D.B., 1984, Cenozoic non-marine sedimentary rocks of the Farewell fault zone, McGrath Quadrangle, Alaska: Sedimentary Geology, v. 38, no. 1-4, p. 443-463.

Gilbert, W.G., Solie, D.N., and Dickey, D.B., 1982, Preliminary bedrock geology of the McGrath B-3 Quadrangle: Alaska Division of Geological \& Geophysical Surveys Alaska Open-File Report 148, 1 sheet, scale 1:40,000. doi:10.14509/68

Kirschner, C.E., 1994, Interior basins of Alaska, in Plafker, George, and Berg, H.C, eds., The Geology of Alaska: Boulder, Colorado, Geological Society of America, The Geology of North America, v. G-1, p. 469-493.

Meyer, J.F., and Krouskop, D.L., 1984, Preliminary gravity data, Holitna basin, south-central Alaska: Alaska Division of Geological \& Geophysical Surveys, Report of Investigations 84-25, 6 p., 2 sheets, scale 1:500,000.

LePain, D.L., Blodgett, R.B., and Clough, J.G., 2003, Sedimentology and hydrocarbon source rock potential of Miocene-Oligocene strata, McGrath Quadrangle: An outcrop analog for the Holitna Basin: Alaska Division of Geological \& Geophysical Surveys Preliminary Interpretive Report 2002-5, 75 p. doi:10.14509/2870
Peters, K.E., 1986, Guidelines for evaluating petroleum source rocks using programmed pyrolysis: American Association of Petroleum Geologists Bulletin, v. 70, no. 3, p. 318-329.

Peters, K.E., and Cassa, M.R., 1994, Applied source rock geochemistry, in Magoon, L.B., and Dow, W.G, eds., The Petroleum System-From Source to Trap: Association of American Petroleum Geologists Memoir, v. 60, p. 93-120.

Petersen, H.I., 2006, The petroleum generation potential and effective oil window of humic coals related to coal composition and age: International Journal of Coal Geology, v. 67 , no. 4 , p. $221-248$.

Potter, P.E., Maynard, J.B., and Depetris, P.J., 2005, Mud and Mudstones - Introduction and Overview: Heidelberg, Springer-Verlag, 297 p.

Ridgway, K.D., Trop, J.M., and Sweet, A.R., 2000, Stratigraphy, depositional systems, and age of the Tertiary White Mountain basin, Denali fault system, southwestern Alaska, in Pinney, D.S., and Davis, P.K., eds., Short Notes on Alaska Geology 1999: Alaska Division of Geological \& Geophysical Surveys Professional Report 119F, p. 77-84. doi:10.14509/2688

Smith, T.N., Clough, J.G., Meyer, J.F., and Blodgett, R.B., 1985, Petroleum potential and stratigraphy of Holitna basin, Alaska [abs.]: American Association of Petroleum Geologists Bulletin, v. v.69, p. 308.

Solie, D.N., and Dickey, D.B., 1982, Coal occurrences and analyses, Farewell-White Mountain area: Alaska Division of Geological \& Geophysical Surveys Alaska Open-File Report 160, 20 p., 1 sheet, scale 1 inch $=20$ meters. doi:10.14509/95

Stanley, R.G., 1987, Effects of weathering on petroleumsource evaluation of coals from the Suntrana Formation near Healy, Alaska, in Hamilton, T.D., and Galloway, J.P., eds., Geologic Studies in Alaska by the U.S. Geological Survey during 1986, p. 99-103.

Stanley, R.G., Lillis, P.G., Pawlewicz, M.J., and Haeussler, P.J., 2014, Rock-Eval pyrolysis and vitrinite reflectance results from the Sheep Creek 1 well, Susitna basin, southcentral Alaska: U.S. Geological Survey Open-File Report 2013-1307, $12 \mathrm{p}$.

Sykes, R., and Snowdon, L.R., 2002, Guidelines for assessing the petroleum potential of coaly source rocks using Rock-Eval pyrolysis: Organic Geochemistry, v. 33, no. 12 , p. 1,441-1,455.

Wilson, F.H., Dover, J.H., Bradley, D.C., Weber, F.R., Bundtzen, T.K., and Haeussler, P.J., 1998, Geologic map of central (interior) Alaska: U.S. Geological Survey OpenFile Report 98-133-A, 62 p., 3 sheets. 



\title{
APPENDIX
}

\section{Geochemical Analysis of Holitna Outcrop Samples Series "WF" North Slope, Alaska}

\author{
Prepared for: \\ State of Alaska \\ Department of Natural Resources \\ Division of Geological \& Geophysical Surveys
}

Prepared by:

Wallace G. Dow

Project: $02 / 011$

June 24, 20003 


\section{GEOCHEMICAL ANALYSIS OF WF SERIES HOLITNA OUTCROPS NORTH SLOPE OF ALASKA}

Forty-two "WF" Holitna outcrop samples vary considerably in total organic carbon (1.11 - 70.24 wt. \% TOC) and many contain significant percentages of low rank, bituminous coal. Rock-Eval response also is variable and many samples appear to have moderate hydrocarbon generating capabilities based on their hydrogen indices. Pyrolysis Tmax values are very low and all of the samples are in the pre-oil generation maturity zone (less than $435^{\circ} \mathrm{F}$.). Some variation in $\operatorname{Tmax}$ data may be due to traces of solid bitumen in some of the samples. Pyrolysis S1/TOC ratios and production indices $(\mathrm{PI})$ are consistently low and indicate lack of significant liquid hydrocarbons in the samples.

Kerogen microscopy on nineteen of the samples reveal that they all contain very high percentages of lipid-rich (fluorescent) vitrinite and only minor amounts of structured and unstructured lipid material. Vitrinite reflectance maturities range from 0.42 to $0.59 \%$ Ro and average about $0.47 \%$ Ro and some of the reflectance measurements may be very slightly suppressed by fluorescent $b$ itumen. These s amples a re classified as s ub-bituminous to $h$ igh volatile "C" bituminous humic coals and are in the late pre-oil generation maturity zone. Because they occur at the present surface, a considerable amount of overburden has been removed since maximum burial took place.

Solvent extraction and whole extract gas chromatography was done on eight of the samples to define the nature of the fluorescent bitumen material they contain and to verify their organic facies and thermal maturity. Total organic extract contents are quite high, but the extract/TOC ratios are low, indicating a lack of indigenous or migrated oil in the samples. This is characteristic of immature humic coals. Pristane/phytane ratios between 1.8 and 6.1 and the position of the samples on the $\mathrm{Pr} / \mathrm{nC} 17 \mathrm{vs}$. ph/nC18 plot a re b oth consistent with immature, terrigenous organic matter and peat-coal depositional environments. Whole extract gas chromatograms exhibit very little oil-like material and also show distinct odd-carbon predominance in the $\mathrm{nC} 20$ to $\mathrm{nC} 35$ normal alkanes (also expressed by high OEP indices). This is especially evident in the sample 80 WF gas chromatogram, but the different appearance is due primarily to instrument attenuation variations (note the relative heights of the pristine $(\mathrm{Pr}$ ) peaks between sample $80 \mathrm{WF}$ and the others). This odd-carbon predominance in the heavy alkanes is typically found in samples containing terrigenous structured lipids such as cutinite with pre-oil generation maturities. 


\section{ORGANIC CARBON AND PYROLYSIS DATA}

Total Organic Carbon (TOC) and Rock-Eval pyrolysis data provide basic geochemical information and are frequently used to select samples for more detailed studies, particularly kerogen microscopy, extract chromatography and biomarker analyses. Well data can be plotted to make geochemical logs. Unless otherwise specified by a client, DGSI uses LECO TOC then Rock-Eval II pyrolysis as the standard analytical sequence and Rock-Eval is recommended for samples with greater than $0.4 \%$ TOC. Samples for LECO TOC and Rock-Eval pyrolysis are ground to pass through a 60 mesh sieve to assure homogeneity.

\section{LECO Organic Carbon and Total Sulfur}

Total Organic Carbon is best determined by direct combustion. Approximately 0.15 grams of sample are carefully weighed, treated with concentrated $\mathrm{HCl}$ to remove carbonates, and vacuum filtered on glass fiber paper. The residue and paper are placed in a ceramic crucible, dried, and combusted with pure oxygen in a LECO EC-12 or LECO CS- 444 carbon analyzer at about $1,000^{\circ} \mathrm{C}$. A laboratory standard is run every five samples. Total, insoluble, mineral plus organic sulfur can be determined by the CS-444 analyzer during the carbon analysis. Total carbonate can be determined from sample and acid residue weight differences or by LECO combustion TOC differences before and after acid digestion.

\section{Rock-Eval II Pyrolysis}

Rock-Eval II pyrolysis is used to determine kerogen type, kerogen maturity and the amount of free hydrocarbons. About 0.1 grams of the same ground sample used for LECO TOC are carefully weighed in a pyrolysis crucible and then heated to $300^{\circ} \mathrm{C}$ to determine the amount of free hydrocarbons, $\mathrm{S}_{1}$, that is thermally distilled. Next, the amount of pyrolyzable hydrocarbons, $\mathrm{S}_{2}$, is measured when the sample is heated in an inert environment which rises from $300^{\circ}$ to $550^{\circ} \mathrm{C}$ at a heating rate of $25^{\circ} \mathrm{C} /$ minute. $\mathrm{S}_{1}$ and $\mathrm{S}_{2}$ are reported in $\mathrm{mg} \mathrm{HC} / \mathrm{g}$ sample. $\mathrm{T}_{\max }$, a maturity indicator, is the temperature of maximum $\mathrm{S}_{2}$ generation. When $S_{2}$ values are less than $0.2 \mathrm{mg} \mathrm{HC} / \mathrm{g}$ sample, the $S_{2}$ maximum typically has poor definition and thus, Tmax cannot be reliably determined (Peters, 1986). $\mathrm{T}_{\max }$ values are reported as N.A. on samples with 0.00 $\mathrm{S}_{2}$. Carbon dioxide generated during the $\mathrm{S}_{2}$ pyrolysis, an indicator of kerogen oxidation, is collected up to a temperature of $390^{\circ} \mathrm{C}$ and reported as $\mathrm{S}_{3}$ in units of $\mathrm{mg} \mathrm{CO}_{2} / \mathrm{g}$ sample. A laboratory standard is run every 10 samples. Hydrogen Index $\left(\mathrm{HI}=\mathrm{S}_{2} * 100 / \mathrm{TOC}\right)$ and Oxygen Index $\left(\mathrm{OI}=\mathrm{S}_{3} * 100 / \mathrm{TOC}\right)$ are used as kerogen type indicators when plotted on a van Krevelen type diagram.

\section{Rock-Eval II Pyrolysis with TOC}

Rock-Eval II Plus TOC is used to determine both Rock-Eval data $\left(\mathrm{S}_{1}, \mathrm{~S}_{2}, \mathrm{~S}_{3}, \mathrm{~T}_{\max }\right)$ and TOC of a 0.1 gram ground sample. With this instrument, the pyrolysis stage $\left(\mathrm{S}_{2}\right)$ ramps to $600^{\circ} \mathrm{C}$ at which point the sample is switched to an oxidation oven where the sample is oxidized at $600^{\circ} \mathrm{C}$ for 5 minutes in air to measure the residual organic matter $\left(\mathrm{S}_{4}\right)$. A laboratory standard is run every 10 samples. $\mathrm{S}_{1}, \mathrm{~S}_{2}, \mathrm{~S}_{3}$, and $\mathrm{S}_{4}$ are summed appropriately to calculate TOC. True TOC will be greater than this calculated sum for samples with maturity greater than about $1.0 \% \mathrm{R}_{\mathrm{o}}$ because the Rock-Eval final temperature is inadequate for complete combustion (Peters, 1986). This instrument is preferred when there is insufficient sample to run TOC and pyrolysis separately, or when all samples in a study are to be analyzed for both TOC and RockEval data without prior TOC screening. 

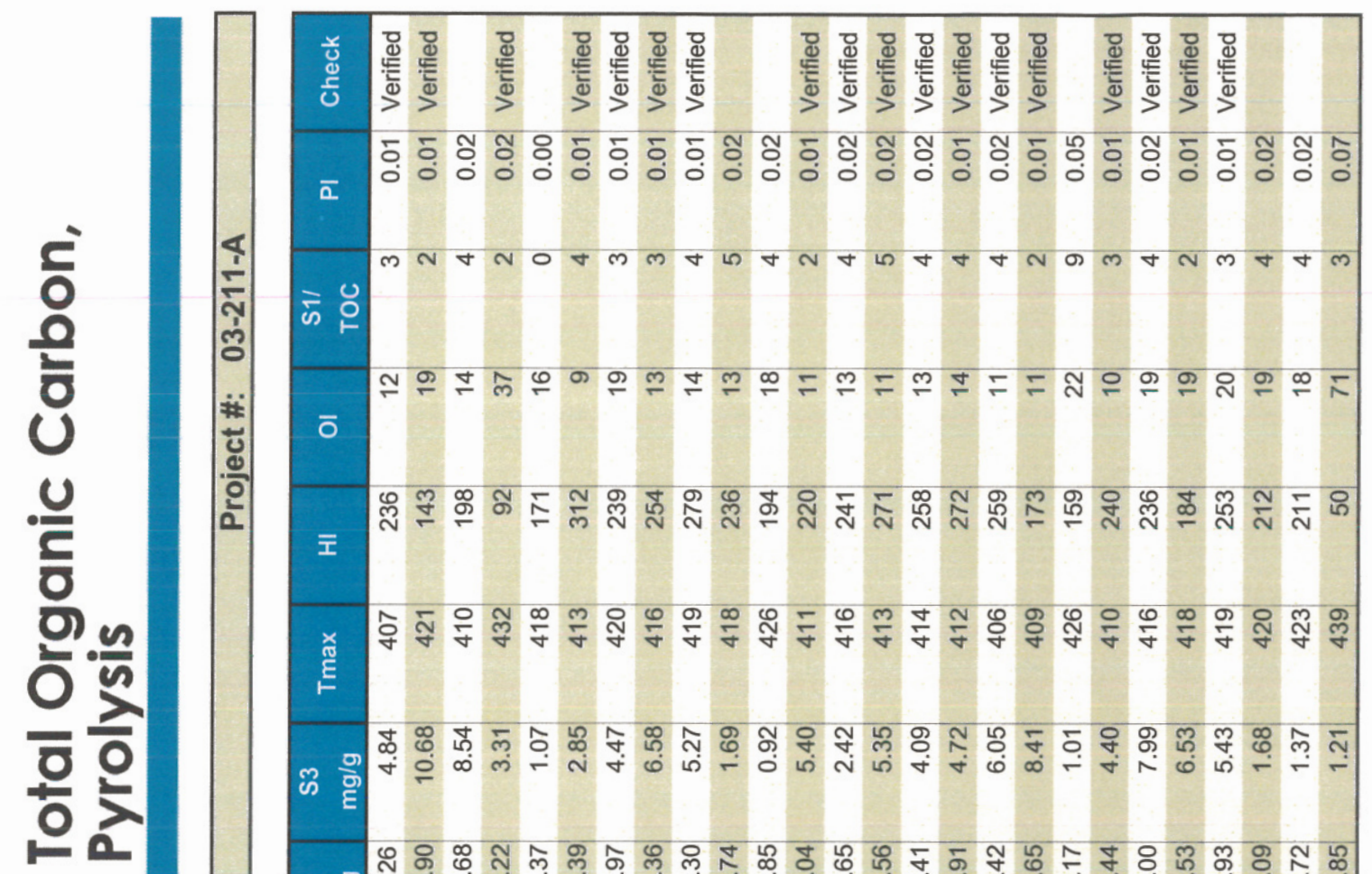

শ্ֶ

党 क के ํํ

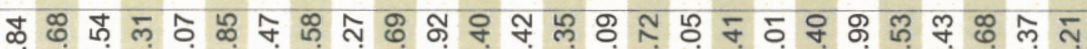

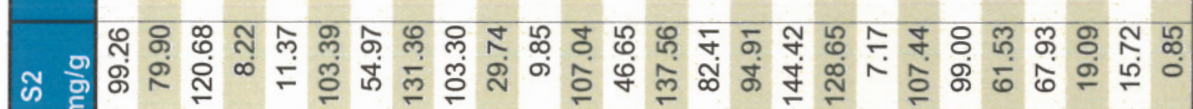

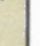
๘

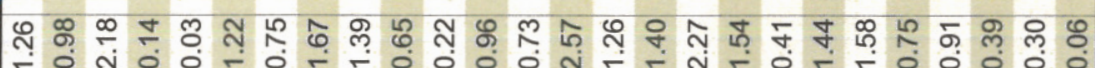
के कू

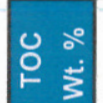

ப ปู่

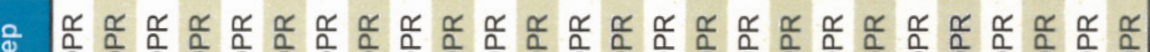

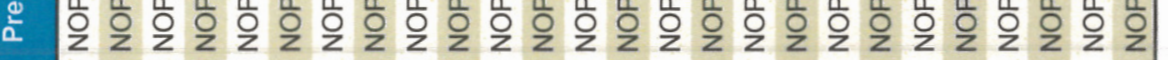

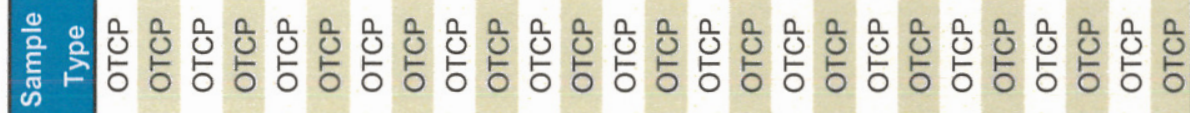

称索守

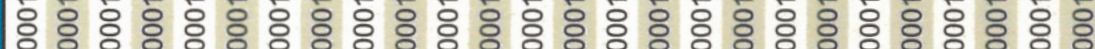

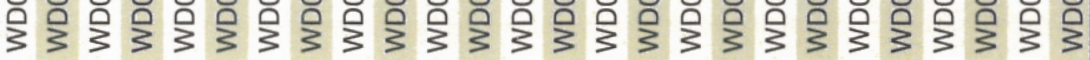

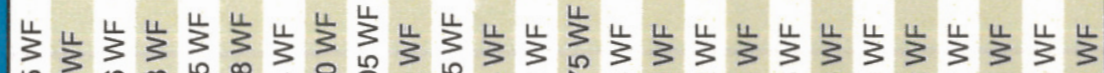

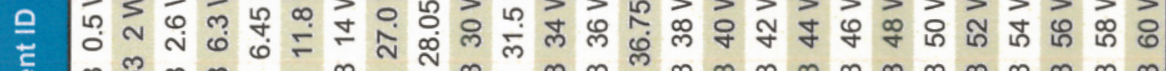

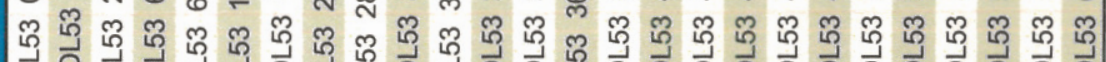

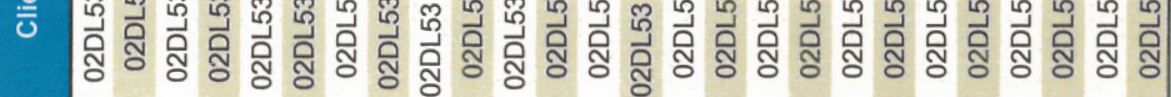
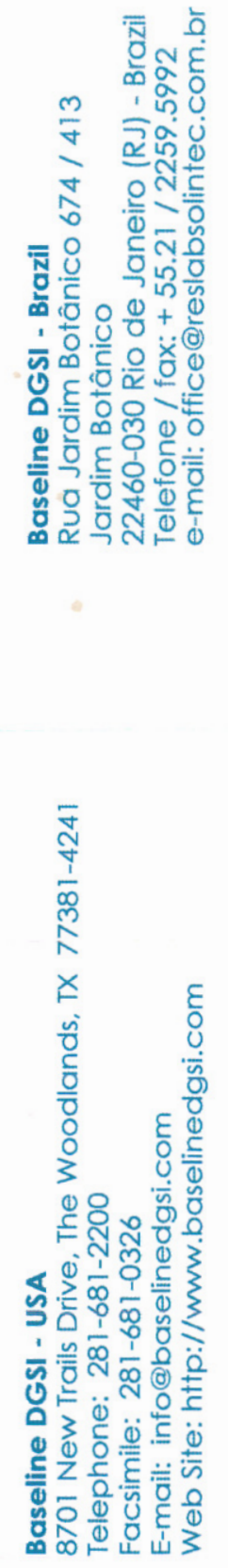

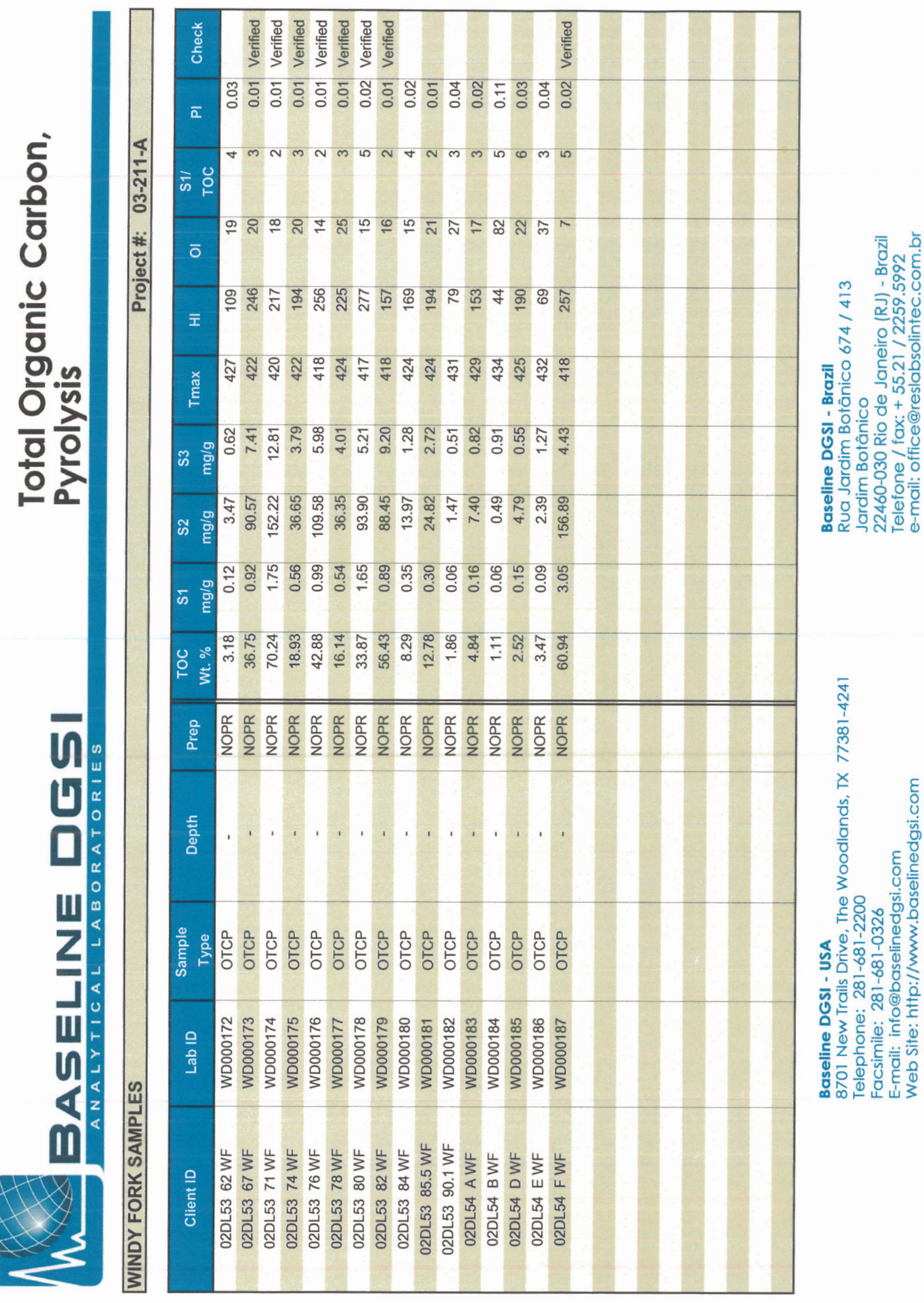


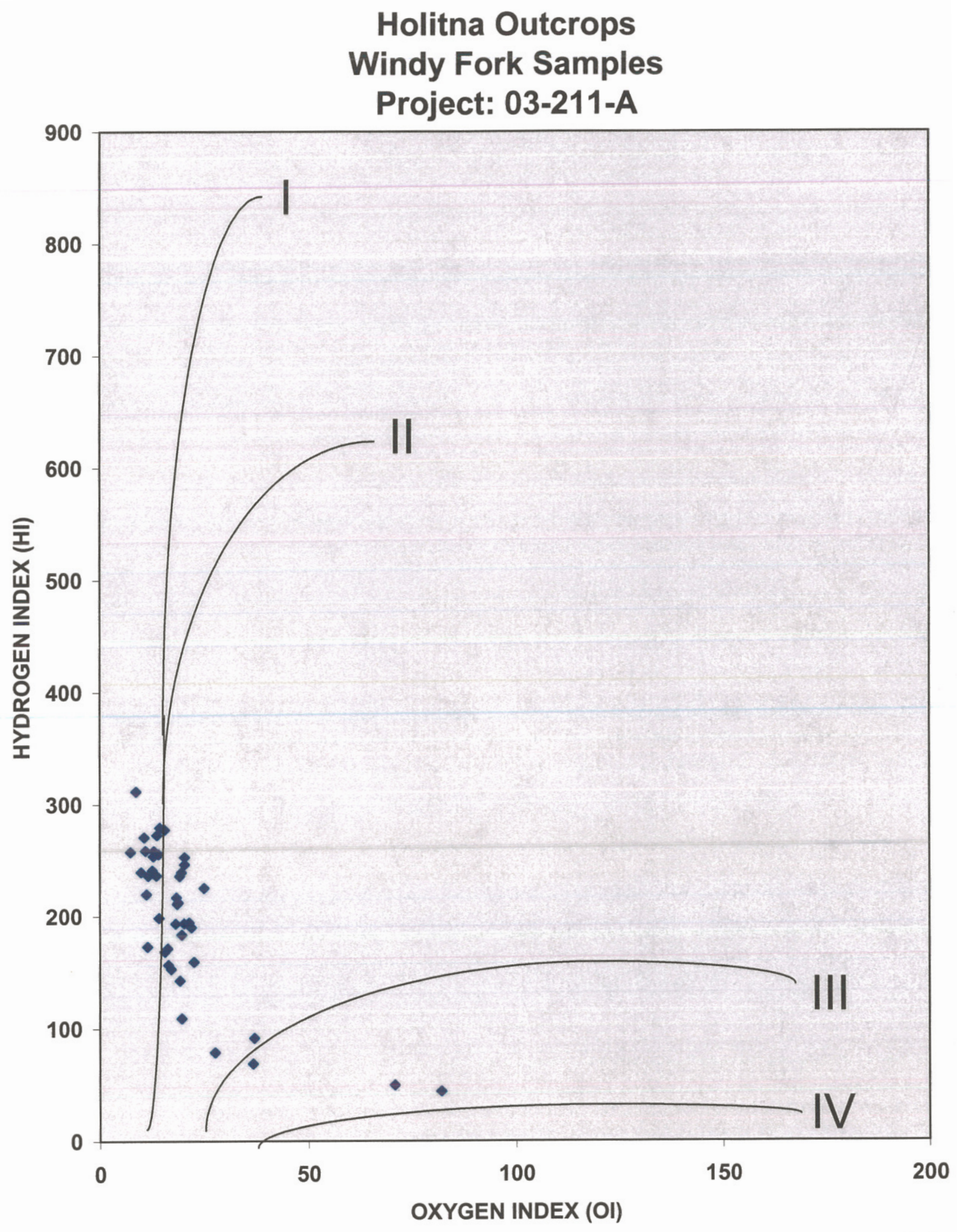

FIGURE - 2 Kerogen type determination from TOC and Rock-Eval pyrolysis data. Types I and II will generate oil, type III gas, and type IV little or no hydrocarbons. 


\section{KEROGEN MICROSCOPY}

A Zeiss Universal microscope system equipped with halogen, xenon, and tungsten light sources is used for v isual kerogen a nalysis. The halogen light source is used for vitrinite reflectance with a digital indicator calibrated on a glass standard with a reflectance of $1.02 \%$ in oil. The xenon light source is used for blue light fluorescence with an excitation filter at $495 \mathrm{~nm}$. and a barrier filter at $520 \mathrm{~nm}$. The tungsten light source is used for TAI analysis.

Vitrinite reflectance measurements are performed on a polished plug in reflected light, TAI is performed on a strewn slide in transmitted light, and kerogen typing and percent of organic matter is estimated from both preparations using a combination of reflected, transmitted, and fluorescent light techniques. Fluorescence is used to enhance the identification of structured and unstructured lipid material, solid bitumen, and drilling mud contaminants. Fluorescence also correlates with the maturity and state of preservation of the organic matter. Kerogen typing indicates, as closely as possible, the original organic constituent and is not reclassified with increasing maturity or changing chemistry.

\section{Vitrinite Reflectance}

Reflectance values are normally recorded only on the best quality vitrinite, including obvious contamination and recycled material. When good quality vitrinite is absent, notations are made that indicate how reflectance values may be affected by rough texture, lipid content, oxidation, or coking. When vitrinite is absent or sparse, other macerals such as solid bitumen or graptolites may be substituted with reflectance correlations indicated on the histogram.

Maturity calculations are made from the vitrinite reflectance histograms. Decisions as to which reflectance measurements indicate the maturity of the sample are based on the histogram and on data from the Visual Kerogen Analysis (VKA) Table. Geochemical and geological information is also used if available. All recorded reflectance values are reported on the histogram and alternate maturity calculations can be made if additional information dictates.

\section{Histograms}

Vitrinite reflectance histograms contain useful information in addition to reflectance values. Sample type, TOC, $\mathrm{T}_{\max }, \mathrm{HI}$, reflectance means, Visual Kerogen Summary, and Comments are also listed.

All reflectance measurements are graphically displayed and the individual readings are listed below the histogram in numerical order with a letter code. The code indicates the type of material on which the measurement was made. Capital letters designate reflectance values used in calculating the mean reflectance for maturity. L ower c ase letters indicate values that are outside the selected maturity range. Reflectance values used for maturity calculations are shaded on the histogram and values outside the selected range are left open.

\begin{tabular}{lll}
\multicolumn{1}{l}{ Reflectance codes are: } & & \\
Vitrinite - V & Solid bitumen - B & Graptolites - G \\
Lipid-rich vitrinite - L & Coked solid bitumen - Y & Inertinite - I \\
Coked vitrinite - Z & Granular solid bitumen - X & Other1 - O \\
& & Other2 - W
\end{tabular}

The two 'other' categories allow the flexibility of measuring unusual materials or contamination from mud additives or caving. Specific information regarding 'other' material is shown in the Comments section at the lower right corner of the Histogram Figure and in the Comments section of the VKA Table.

Statistics for s elected constituents a re listed a djacent to the histogram and the mean reflectance values are also listed below the TOC and R ock-Eval data at the upper $\mathrm{r}$ ight $\mathrm{corner}$ of the Figure. T he measured values for solid bitumen and graptolites may be recalculated using appropriate formulas to obtain a vitrinite reflectance equivalent (VRE). Therefore, for these two macerals we show both the measured reflectance and the VRE. For example, VRE-B is the vitrinite reflectance equivalent for solid bitumen and VRE-G is the vitrinite reflectance equivalent for graptolites - see list under Vit. Reflect. Equivalence at bottom of Visual Kerogen Analysis Table. 


\section{Visual Kerogen Analysis Table (Brief Explanation)}

The VKA Table is a list of the data for each sample. Samples can easily be compared and maturity trends established.

Lab Number - Lab number assigned to client's sample.

Sample ID or Depth - Client's ID or depth of sample.

Preparation/Sample - See list under Sample Type/Prep at bottom of Table.

- $\quad$ Organic Matter (\%) Lipids - Unstructured

Undifferentiated - Unstructured lipids that do not fit in the other groups - oxidized, small amount, etc. Amorphous - Immature unstructured lipids, less than $\mathrm{R}_{0} 0.50 \%$, possibly with remnant algal structures. Massive - Unstructured lipids that have a cohesive texture as the result of polymerization.

Micrinized - Unstructured lipids with granular or fine-grained texture and maturity above $\mathrm{R}_{0} 1.30 \%$.

- $\quad$ Organic Matter (\%) Lipids - Structured

Type - See list under Structured Lipids at bottom of VKA Table.

Type - “

Type - “

Type - “

Solid Bitumen - Expelled hydrocarbon from the maturation of lipid material.

- $\quad$ Organic Matter (\%) Humic

Inertinite - Non-reactive (inert) constituents formed from woody material, fungal structures, etc.

Vitrinite - Derived from woody material.

- $\quad$ Organic Matter (\%) Other

Type - See list under Other Organic Matter at bottom of Table.

Type - "

- $\quad$ Relative Abundance - see list under Abund. at bottom of Table.

Pyrite Type - See list under Pyrite at bottom of Table.

Pyrite - Amount of pyrite observed in the reflected light plug.

Organic Concentration - Amount of organic matter in the reflected light plug - Not TOC.

- Relative Abundance Vitrinite

Normal - Unaltered vitrinite.

Rough - Texture that may be caused by oxidation, dissolving of lipid materials, or coking. Lipid-Rich - Vitrinite that has a higher than normal lipid content resulting in lower $\mathrm{R}_{\mathrm{o}}$ values. Oxidized - Vitrinite that has lower or higher $\mathrm{R}_{\mathrm{o}}$ caused by weathering, microbial activity, or heating. Coked - Texture caused from rapid heating as from intrusions.

- Fluorescence/TAI Reflected Lipids Unstructured

Color - See list under Fluor. Color at bottom of Table. Letters may be combined to indicate color. Intensity - See list under Fluor. Intens. at bottom of Table.

- $\quad$ Fluorescence/TAI Reflected Lipids Structured

Color - See list under Fluor. Color at bottom of Table. Intensity - See list under Fluor. Intens. at bottom of Table.

- $\quad$ Fluorescence/TAI Reflected

Background Intensity - Fluorescence of the epoxy mounting medium around the organic matter.

- $\quad$ Fluorescence/TAI Transmitted Lipids Unstructured - TAI and Fluorescence

Value (TAI) - Color of unstructured lipids in transmitted light - see list under TAI Color Values. Color - See list under Fluor. Color at bottom of Table. Letters may be combined to indicate color. Intensity - See list under Fluor. Intens. at bottom of Table.

- $\quad$ Fluorescence/TAI Transmitted Lipids Structured -- TAI and Fluorescence

Value (TAI) - Color of sporinite of terrestrial origin in transmitted light - see list under TAI Color Values.

Color - See list under Fluor. Color at bottom of Table.

Intensity - See list under Fluor. Intens. at bottom of Table.

- $\underline{R}_{0}$ Vitrinite Reflectance or Equivalent - interpreted value. 


\section{Visual Kerogen Analysis Table (Detailed Explanation)}

The VKA Table is a list of the data for each sample. Samples can easily be compared and maturity trends established

- Lab Number - Lab number assigned to client's sample.

- Sample ID or Depth - Client's identification or depth of sample.

- Preparation/Sample Type - See list under Sample Type/Prep at bottom of Table. Unfloated kerogen concentrates are used to prevent biasing of the organic matter.

ORGANIC MATTER (\%) - Organic material in sedimentary rocks consists of different constituents called macerals. On the VKA Table, these constituents are divided into two groups generally characterized by their chemical composition - Lipids and Humic. A group for Other is included to separate special interest components.

Lipids are divided into two groups - Unstructured and Structured:

Unstructured lipids represent the material resulting from bacterial or thermal breakdown of lipid organic matter. Most unstructured material results from algae, but also may include fecal pellets, organic gels, humic components, and other debris. Unstructured lipid material changes character and texture with increasing maturity or chemical alteration and is divided into four groups:

- Undifferentiated - Unstructured lipids that do not fit in the other groups because of oxidation, mixing with other organic material or mineral that makes identification difficult, or small amounts of organic matter.

- Amorphous - Immature unstructured lipids with generally fluffy texture, light brown or amber color, and possibly remnant algal structure. Maturity is usually less than $\mathrm{R}_{\mathrm{o}} 0.50 \%$.

- Massive - Unstructured lipids that have a cohesive texture as the result of polymerization during the process of oil generation and may contain solid bitumen. Color generally ranges from brown to dark gray and maturity from $R_{0} 0.50$ to $R_{o} 1.30 \%$.

- Micrinized - Unstructured lipids with maturity generally above $\mathrm{R}_{0} 1.30 \%$ and consisting of granular to fine-grained texture. Color is dark gray, light gray, or black.

Structured lipids consist of a group of macerals which have a recognized structure and can be related to the original living tissue from which they were derived - see list under Structured Lipids at bottom of VKA Table.

- Alginite - Derived from algae. It is sometimes very useful to distinguish the different algal types, for example, botryococcus and pediastrum are associated with lacustrine and non-marine source rocks, while algae such as tasmanites, gloecapsomorpha, and nostrocopsis are typically marine. Acritarchs and dinoflagellates are marine organisms that are also included in the algal category.

- Suberinite - Derived from the corky tissue of land plants.

- Cutinite - Derived from plant cuticles, the remains of leaves.

- Liptodetrinite - Structured lipid material with fluorescence that is too small to be specifically identified. Usually, it is derived from alginite or sporinite with maturity less than $R_{o} 1.40 \%$.

- Undifferentiated - Structured lipid material that does not fluoresce and is too small to be specifically identified. Maturity is usually higher than $\mathrm{R}_{0} \quad 1.40 \%$ and sometimes fragments are difficult to distinguish from vitrinite or inertinite.

- Sporinite - Derived from spores and pollen from a wide variety of land plants.

- Resinite - Derived from plant resins, balsams, latexes, and waxes, also includes fluorinite.

- Other - Category for varieties listed above or from contaminants such as nutshell.

- Solid Bitumen - Also called migrabitumen or s olid hydrocarbon, it is a s econdary product formed from the maturation of lipid components. Solid bitumen is an expelled hydrocarbon that has characteristic shape, texture, and fluorescence and is l isted with s tructured lipids. It represents two classes of substances: one which is present at or near the place where it was generated, and the other which is present in reservoir rock and may have migrated a great distance from its point of origin. It is sometimes possible to use the reflectance of solid bitumen for maturation determinations when vitrinite is not present. 
groups:

Humic material is derived from the woody components of land plants and is divided into two

- Inertinite - Derived from woody material that has been matured by a different pathway from that of normal vitrinite. Early intense oxidation, usually involving charring, fungal attack, or biochemical gelification creates the higher reflecting fusinite and semi-fusinite. Sometimes the division between vitrinite and fusinite is transitional. Sclerotinite, fungal remains having a distinct morphology, is considered to be inert. Inertinite, as the name implies, is largely non-reactive "dead carbon" and has an extremely low hydrogen index.

- Vitrinite - Derived from woody material that has been subjected to a minimum amount of oxidation. The rate of change of vitrinite reflectance with increasing temperature is more consistent than for other macerals, and offers the best means of obtaining thermal maturity data in coals and other types of sedimentary rocks.

Other Organic Matter - See list at bottom of Table.

- Exsudatinite - Oil and oily exudates are included in this group. Exsudatinite differs from solid bitumen on the basis of mobility and solubility. We prefer to maintain this distinction although the International Committee for Coal Petrology (I.C.C.P.) has now included solid bitumen with the exsudatinite group.

- Graptolites - Marine organisms that range from the Cambrian to the lower Mississippian. They have a reflectance similar to that of vitrinite and can be used for maturity measurements in the early Paleozoic rocks that do not contain vitrinite.

- Lipid-rich vitrinite, Vitrinite contamination, and Recycled Vitrinite - These groups are often separated from the vitrinite maceral to help in the interpretation of the reflectance data.

RELATIVE ABUNDANCE - The relative amounts of items listed below. See list under Abund. at bottom of Table.

- $\quad$ Pyrite Type - See list under Pyrite at bottom of Table.

- Pyrite - Amount of pyrite observed in the reflected light plug.

- Organic Concentration - Amount of organic matter observed in the reflected light plug. (Not to be confused with T otal Organic Carbon). Concentration is a function of the amount of organic matter recovered after acid treatment as well as the amount of epoxy mounting medium that it is mixed with to form the plug. Kerogen typing and percentages are more accurate with larger amounts of organic material.

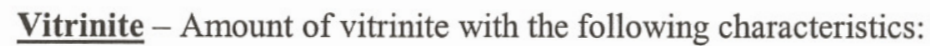

- Normal - Unaltered vitrinite. Reflectance measurements of vitrinite are important and care is taken to distinguish normal from other kinds of vitrinite for accurate reflectance measurements.

- Rough - Texture that may be caused by oxidation, dissolving of lipid materials, or coking. Rough texture lowers reflectance values.

- Lipid-Rich - Vitrinite that has a higher than n ormal 1 ipid c ontent c aused by type of o riginal p lant material, depositional environment, or bitumen saturation. Lipid-rich vitrinite has a lower reflectance than normal vitrinite, depending upon the amount of lipid content, and may produce an abnormally low maturity value. It is identified by visual characteristics and fluorescence.

- Oxidized - Oxidized vitrinite may have a reflectance lower or higher than normal vitrinite, depending on the method of oxidation and when it took place during the maturation process. Weathering and microbial degradation generally cause a darker surface resulting in lowered reflectance values. Heating generally causes a lighter surface resulting in higher reflectance values. Vitrinite fragments may exhibit dark or light oxidation rims or crusts, or be completely oxidized. Various depths of polishing of oxidized vitrinite fragments in the reflected light plug make differentiation of normal and oxidized fragments difficult. As a result, a sample with oxidized vitrinite may exhibit a wide range of reflectance values.

- Coked - Naturally coked vitrinite is the product of very rapid heating, such as that found adjacent to intrusions. During the coking process, vitrinite goes through a softening stage that affects texture and color and lowers reflectance values. With continued heating, the vitrinite becomes anisotropic and reflectance rises. With both high temperature and pressure, graphite is produced.

FLUORESCENCE/TAI - Blue light fluorescence is performed on the reflected light plug and on the strewn slide to help identify the lipid components not visible in the other types of light. Fluorescence is also 
used to estimate maturity. Fluorescence color in the range we analyze changes from yellow to black with increasing maturity. However, oxidation and other factors may affect the color and intensity of fluorescence. TAI is performed on the strewn slide using transmitted light from the tungsten light source. On the VKA Table, the two sample preparations are divided into Reflected Light and Transmitted Light categories.

Reflected Light Lipids are divided into two groups - Unstructured and Structured:

Unstructured - See previous definition under Organic Matter \%.

- Color - See list under Fluor. Color at bottom of T able. L etter abbreviations may be c ombined to indicate color, such as OB for orange-brown, LY for light-yellow, etc. Two sets of letters may be used to indicate a range of colors. The most abundant color is reported at the top.

- Intensity - See list under Fluor. Intens. at bottom of Table. Two numbers may be listed to indicate a range of intensity. The most abundant intensity is reported at the top.

Structured - See previous definition under Organic Matter \%.

- Color - See list under Fluor. Color at bottom of Table.

- Intensity - See list under Fluor. Intens. at bottom of Table.

- Background Intensity - The intensity of fluorescence of the epoxy mounting medium used to bind the organic material together for the reflected light plug. The intensity of fluorescence correlates well with the onset of oil generation and destruction. It is also used to detect contamination.

Transmitted Light Lipids are also divided into two groups - Unstructured and Structured. The fluorescence of lipids in the strewn slide is not masked by background fluorescence as in the reflected light plug.

Unstructured - See previous definition under Organic Matter \%.

- Value (TAI) - Color of unstructured lipids in transmitted light represented by a number - see list under TAI Color Values at bottom of Table. Weathering (oxidation), presence of solid bitumen, and micrinization $\mathrm{c}$ an $\mathrm{d}$ arken the kerogen and $\mathrm{r}$ aise the TAI $\mathrm{v}$ alue. $\mathrm{T}$ wo $\mathrm{s}$ ets of $\mathrm{v}$ alues may be used to indicate a range of color. The most abundant color is reported at the top.

- Color - See list under Fluor. Color at bottom of Table.

- Intensity - See list under Fluor. Intens. at bottom of Table.

Structured - See previous definition under Organic Matter \%.

- Value (TAI) - Color of sporinite of terrestrial origin in transmitted light represented by a number - see list under TAI Color Values at bottom of Table.

- Color - See list under Fluor. Color at bottom of Table.

- Intensity - See list under Fluor. Intens. at bottom of Table.

$\mathbf{R}_{\mathbf{0}}$ - The vitrinite reflectance or equivalent mean obtained from the histogram. 


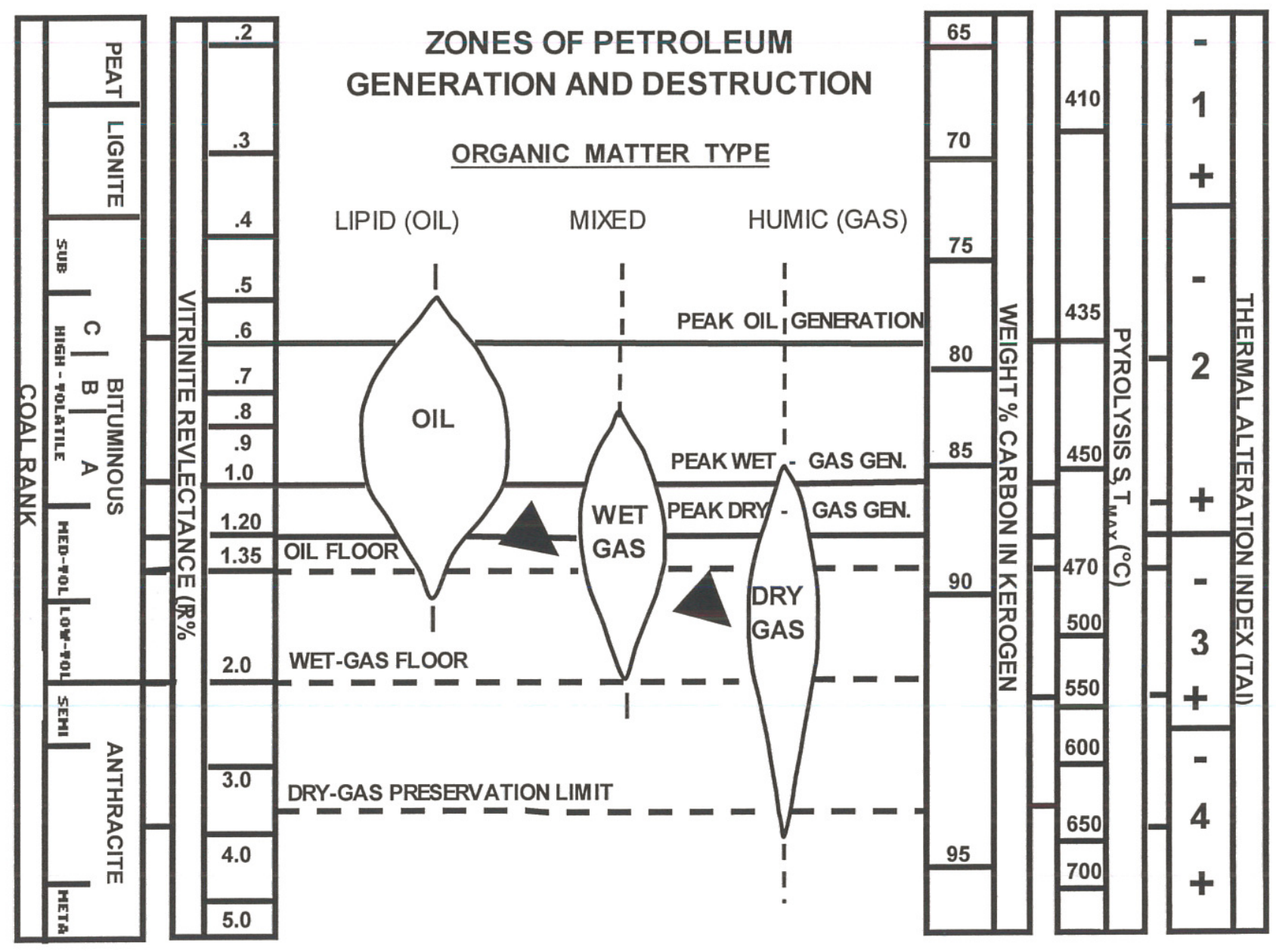

CORRELATION OF VARIOUS MATURATION INDICES AND ZONES OF PETROLEUM GENERATION AND DESTRUCTION 


\section{Holitna Outcrop Windy Fork Samples BaselineDGSI Project: 03-211-A}

\section{Summary of Visual Kerogen Analysis}

Nineteen outcrop samples were analyzed for vitrinite reflectance maturity, TAI maturity, and kerogen type. Some reflectance values may be lowered by suppression or slightly rough texture. Pyrolysis $\mathrm{T}_{\max }$ values may be slightly lowered by lipid content. Maturity interpretations are based on visual analysis and pyrolysis data, but may change with additional geological and geochemical information.

\section{WD000146: 02DL53 0.5 WF}

Organic matter consists of lipid-rich vitrinite with some unstructured material that may be degraded humic debris. Organic matter is slightly immature for oil generation.

\section{WD000148: 02DL53 2.6 WF}

Organic matter is similar to that in sample 02DL53 $0.5 \mathrm{WF}$. Organic matter is slightly immature for oil generation.

\section{WD000151: 02DL53 11.8 WF}

Organic matter consists primarily of lipid-rich vitrinite. Unstructured material is laminated with the vitrinite and may be unstructured lipids. Unstructured lipid material is difficult to identify as lipid or humic when mixed with low-rank, lipid-rich vitrinite, especially in the transmitted light slide. Organic matter is slightly immature for oil generation.

\section{WD000154: 02DL53 28.05 WF}

Organic matter is similar to that in sample 02DL53 11.8 WF. The unstructured material is difficult to identify as humic debris or lipids. Organic matter is slightly immature for oil generation.

\section{WD000157: 02DL53 34 WF}

Organic matter consists of lipid-rich vitrinite and unstructured material that appears to be lipid. The unstructured material does not fluoresce and may be oxidized. Organic matter is slightly immature for oil generation.

\section{WD000160: 02DL53 38 WF}

Organic matter consists of lipid-rich vitrinite with a small amount of unstructured material. Organic matter is slightly immature for oil generation.

\section{WD000162: 02DL53 42 WF}

Organic matter consists of lipid-rich vitrinite and unstructured material that is difficult to identify as humic debris or lipids. Organic matter is slightly immature for oil generation. 


\section{WD000163: 02DL53 44 WF}

Organic matter consists of slightly lipid-rich vitrinite with a trace of unstructured lipids. Maturity is at the top of the oil generation zone.

\section{WD000165: 02DL53 48 WF}

Organic matter consists of lipid-rich vitrinite and unstructured material that is probably lipid. Organic matter is slightly immature for oil generation.

\section{WD000168: 02DL53 54 WF}

Organic matter consists of lipid-rich vitrinite and unstructured material. Some fragments of lipid-rich vitrinite have inclusions of structured lipids that do not fluoresce. The unstructured material is difficult to identify, but some appears to be lipid. Most reflectance values may be suppressed. Maturity is estimated to be at the top of the oil generation zone.

\section{WD000170: 02DL53 58 WF}

Organic matter consists of lipid-rich vitrinite and unstructured material. The unstructured material is difficult to identify as humic debris or lipids. Moderately rough texture or suppression may lower all reflectance values. Maturity is estimated to be slightly immature for oil generation.

\section{WD000172: 02DL53 62 WF}

Organic matter consists of lipid-rich vitrinite with slight to moderate rough texture. Some reflectance values may be lowered by suppression or rough texture. Most lipidrich vitrinite has orange fluorescence in the transmitted light slide. The unstructured material is difficult to identify. Organic matter is slightly immature for oil generation.

\section{WD000174: 02DL53 71 WF}

Organic matter consists of lipid-rich vitrinite and some unstructured material. Most vitrinite has a high lipid content with some resinite, sporinite, and liptodetrinite structure still visible. Reflectance values may be suppressed. Some unstructured material appears to be lipid. Organic matter is slightly immature for oil generation.

\section{WD000176: 02DL53 76 WF}

Organic matter consists of lipid-rich vitrinite and some unstructured material. Some vitrinite fragments have a high lipid content with some resinite, sporinite, and liptodetrinite structure still visible. Some reflectance values may be slightly suppressed. Some unstructured material appears to be lipid. Organic matter is slightly immature for oil generation.

\section{WD000178: 02DL53 80 WF}

Organic matter consists of lipid-rich vitrinite. Some fragments are laminated with unstructured material that is difficult to identify. Reflectance values may be suppressed. Organic matter is slightly immature for oil generation. 


\section{WD000181: 02DL53 85.5 WF}

Organic matter consists of lipid-rich vitrinite and unstructured lipids with grainy-massive texture. Lipid-rich vitrinite has moderately rough texture and reflectance values may be slightly lowered. Organic matter is slightly immature for oil generation.

\section{WD000183: 02DL54 A WF}

Organic matter consists of lipid-rich vitrinite and unstructured lipids. Lipid-rich vitrinite has moderately rough texture that may slightly lower some reflectance values. Maturity is at the top of the oil generation zone.

\section{WD000185: 02DL54 D WF}

Organic matter consists of lipid-rich vitrinite and unstructured material that is difficult to identify. Maturity is at the top of the oil generation zone.

\section{WD000187: 02DL54 F WF}

Organic matter consists of normal vitrinite laminated with liptodetrinite and some lipidrich vitrinite. Most lipid-rich vitrinite is too rough textured for valid reflectance measurements. Maturity is in the upper oil generation zone. 


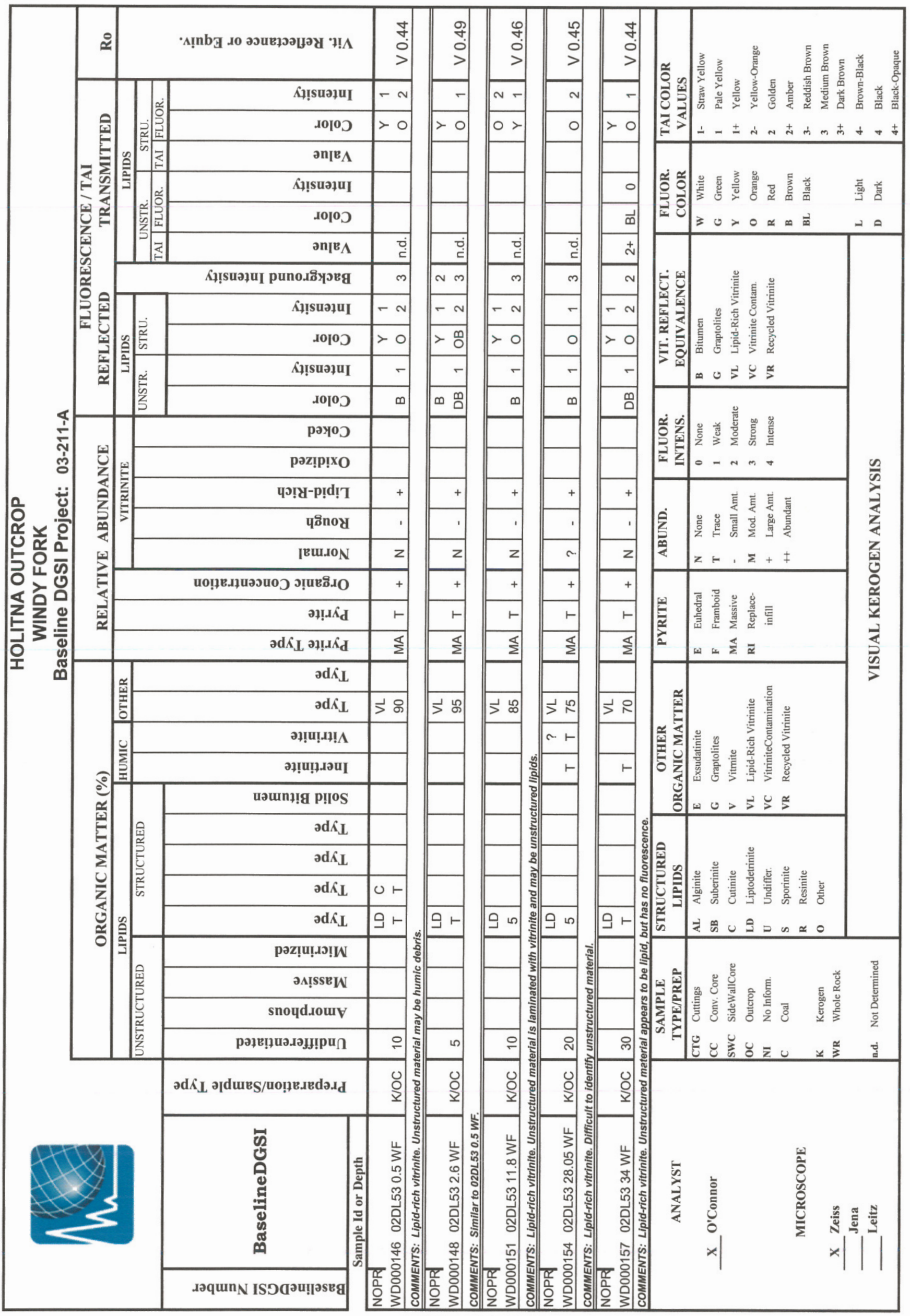




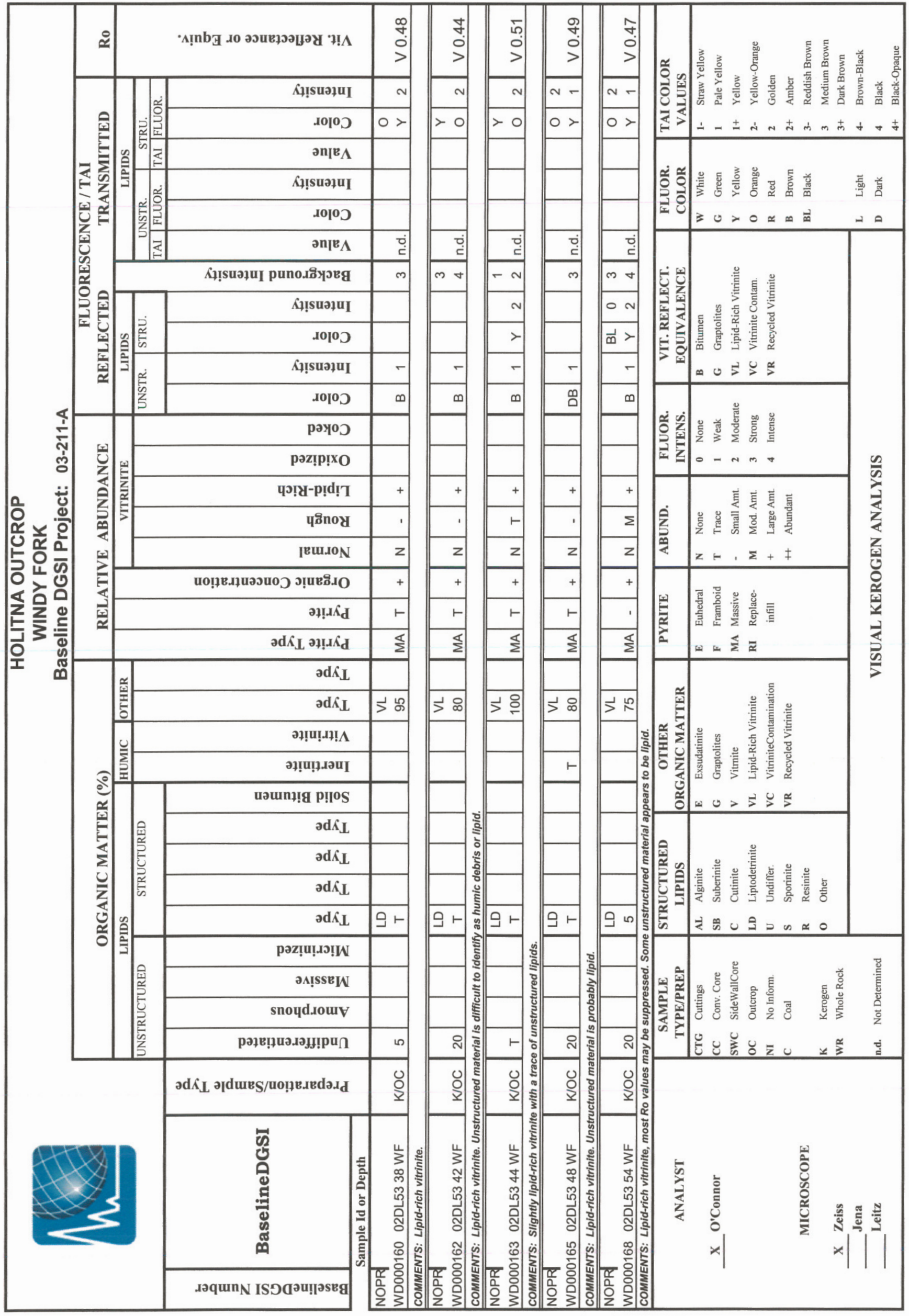




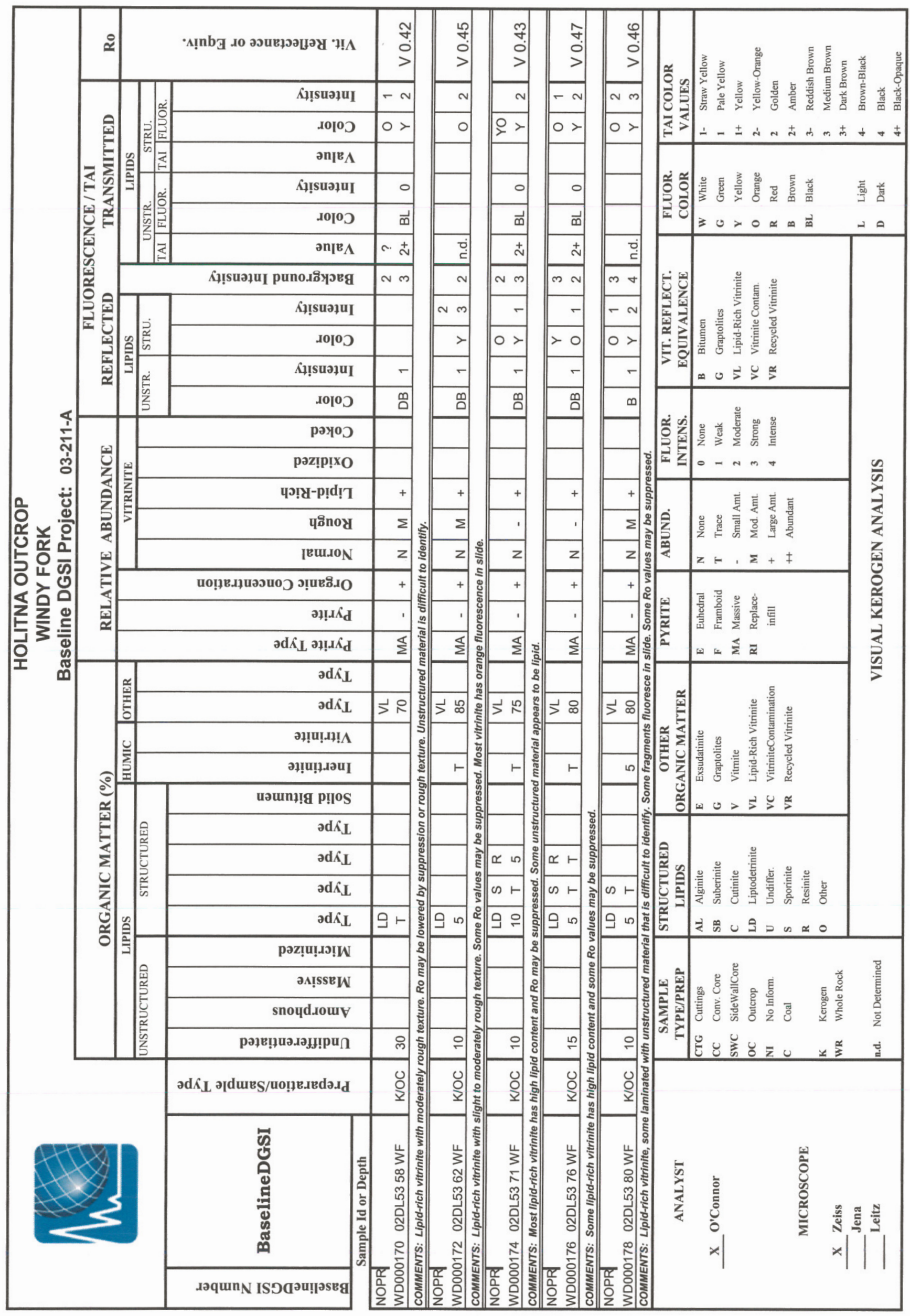




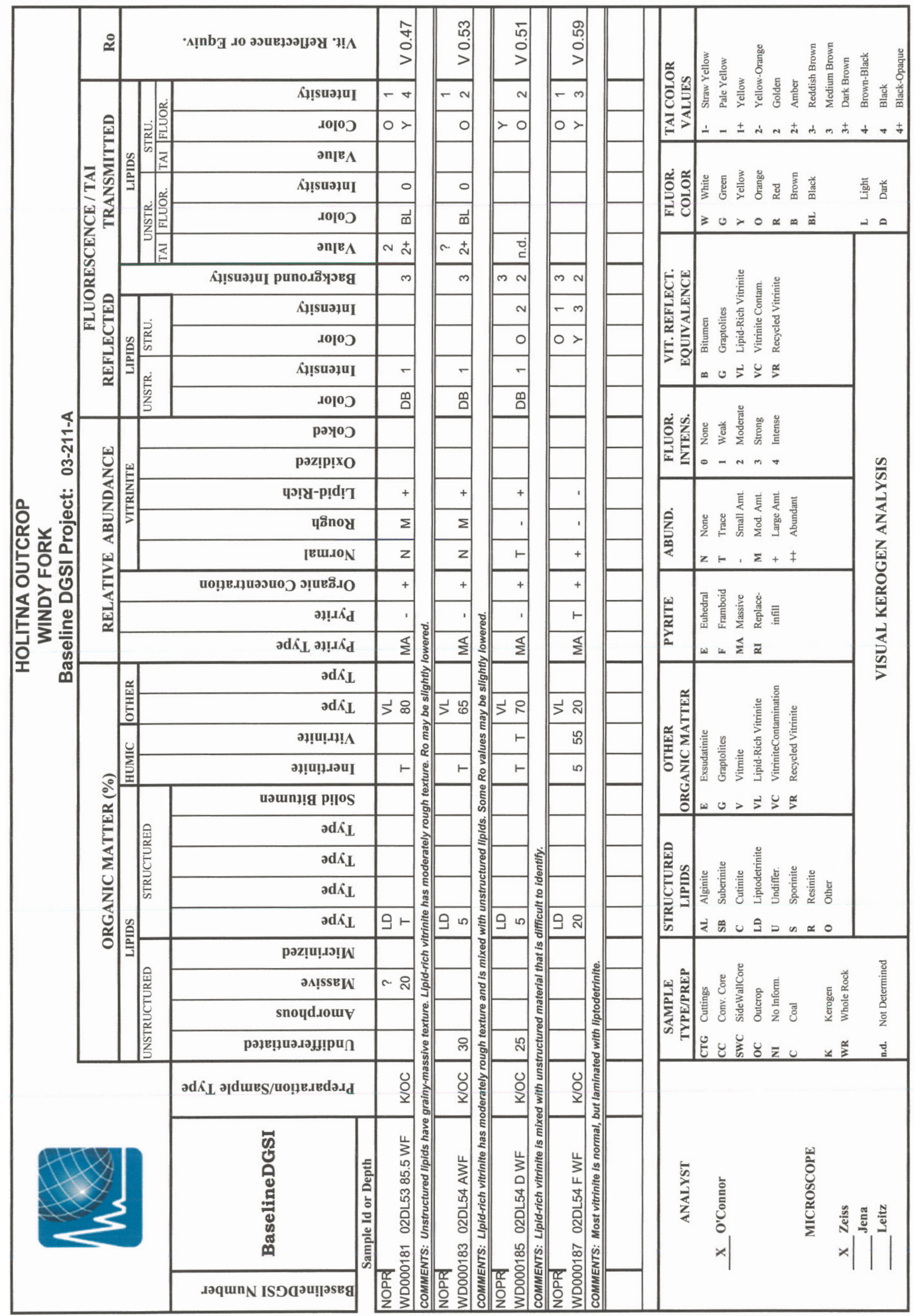




\section{BASELINE DCSI VITRINITE REFLETANCE}

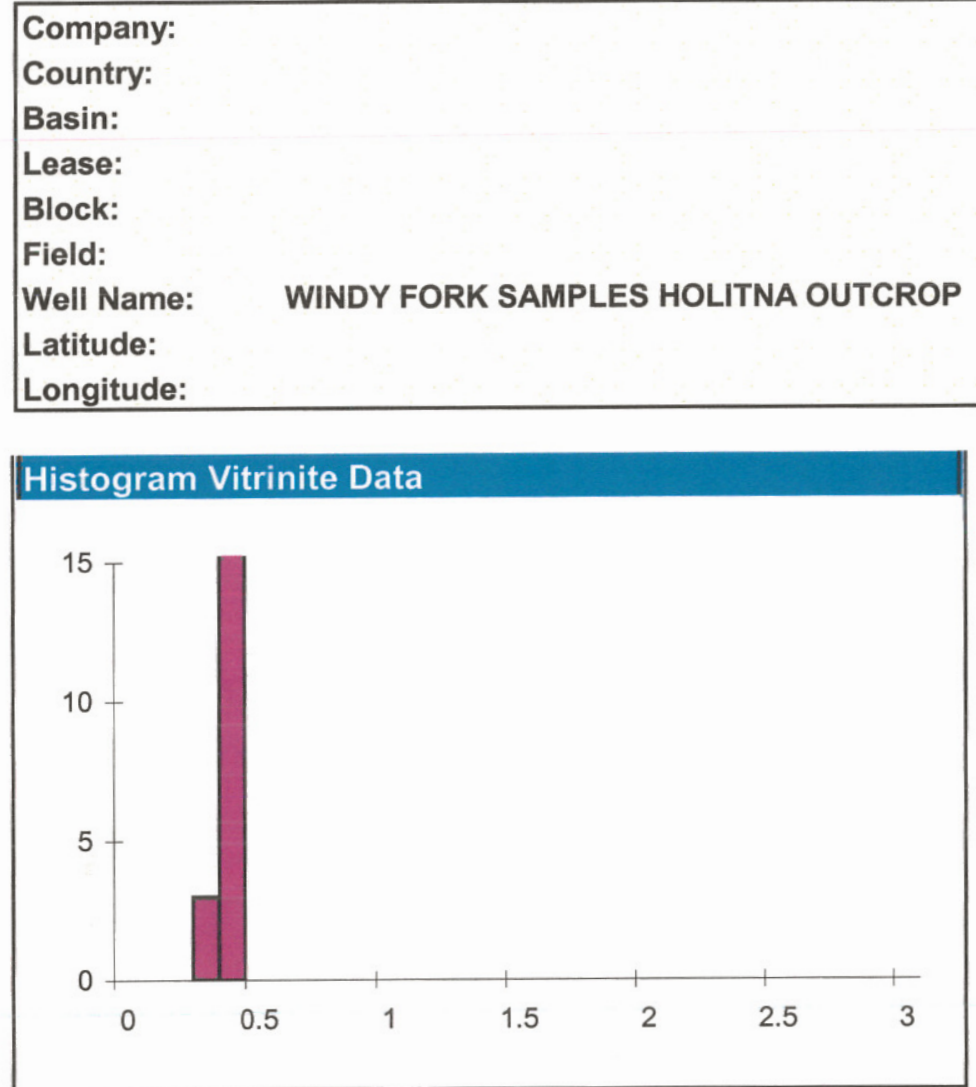

\begin{tabular}{||ll||}
\hline Vitrinite Data: \\
\hline 0.38 & L0.48 \\
$\mathrm{L} 0.38$ & $\mathrm{~L} 0.48$ \\
$\mathrm{~L} 0.39$ & $\mathrm{~L} 0.49$ \\
$\mathrm{~L} 0.401$ & $\mathrm{~L} 0.49$ \\
$\mathrm{~L} 0.401$ & \\
$\mathrm{~L} 0.401$ & \\
$\mathrm{~L} 0.401$ & \\
$\mathrm{~L} 0.41$ & \\
$\mathrm{~L} 0.41$ & \\
$\mathrm{~L} 0.43$ & \\
$\mathrm{~L} 0.43$ & \\
$\mathrm{~L} 0.44$ & \\
$\mathrm{~L} 0.44$ & \\
$\mathrm{~L} 0.45$ & \\
$\mathrm{~L} 0.45$ & \\
$\mathrm{~L} 0.47$ & \\
$\mathrm{~L} 0.47$ & \\
$\mathrm{~L} 0.48$ & \\
$\mathrm{~L} 0.48$ & \\
\hline
\end{tabular}

Client ID:

Project \#:

Lab ID:

Sample Type:

Sampling Point:

Formation:

Geologic Age:

Top Depth:

Bottom Depth:

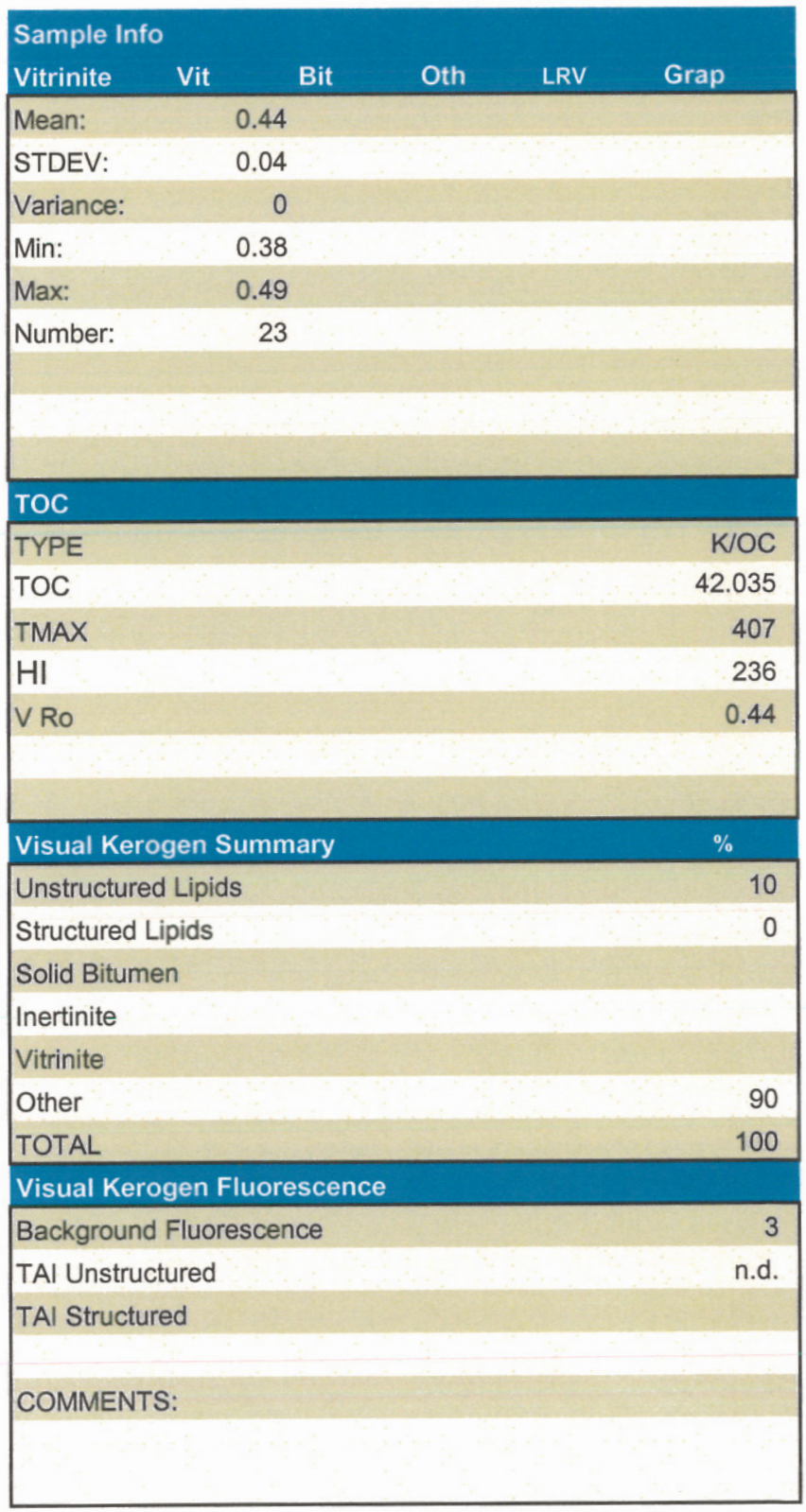

02DL53 0.5 WF

03-211-A

WD000146

OTCP
Baseline/DGSI - USA

8701 New Trolive Toodiands, TX 77381-4241

Telephone: 281-681-2200

E-mail: info@baselinedgsi.com

E-mail: infoabaselnedgsi.clin 


\section{BASELINE DGSI VITRINITE REFLECTANCE}

\begin{tabular}{|lll|}
\hline Company: & Client ID: & 02DL53 2.6 WF \\
Country: & Project \#: & 03-211-A \\
Basin: & Lab ID: & WD000148 \\
Lease: & Sample Type: & OTCP \\
Block: & Sampling Point: & \\
Field: & Formation: & \\
Well Name: & WINDY FORK SAMPLES HOLITNA OUTCROP & Geologic Age: \\
Latitude: & & Top Depth: \\
Longitude: & Bottom Depth: \\
\hline
\end{tabular}

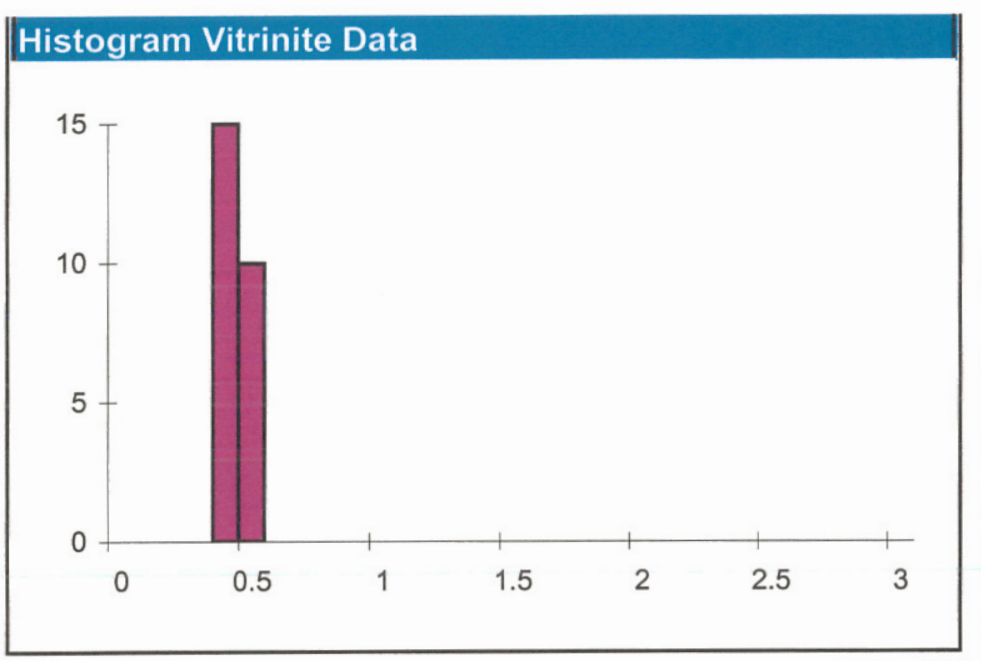

\begin{tabular}{||ll||}
\hline Vitrinite Data: \\
$\mathrm{L} 0.44$ & $\mathrm{~L} 0.51$ \\
$\mathrm{~L} 0.44$ & $\mathrm{~L} 0.52$ \\
$\mathrm{~L} 0.45$ & $\mathrm{~L} 0.52$ \\
$\mathrm{~L} 0.45$ & $\mathrm{~L} 0.53$ \\
$\mathrm{~L} 0.46$ & $\mathrm{~L} 0.54$ \\
$\mathrm{~L} 0.47$ & $\mathrm{~L} 0.54$ \\
$\mathrm{~L} 0.47$ & \\
$\mathrm{~L} 0.48$ & \\
$\mathrm{~L} 0.48$ & \\
$\mathrm{~L} 0.48$ & \\
$\mathrm{~L} 0.49$ & \\
$\mathrm{~L} 0.49$ & \\
$\mathrm{~L} 0.49$ & \\
$\mathrm{~L} 0.49$ & \\
$\mathrm{~L} 0.49$ & \\
$\mathrm{~L} 0.501$ & \\
$\mathrm{~L} 0.51$ & \\
$\mathrm{~L} 0.51$ & \\
$\mathrm{~L} 0.51$ & \\
\hline
\end{tabular}

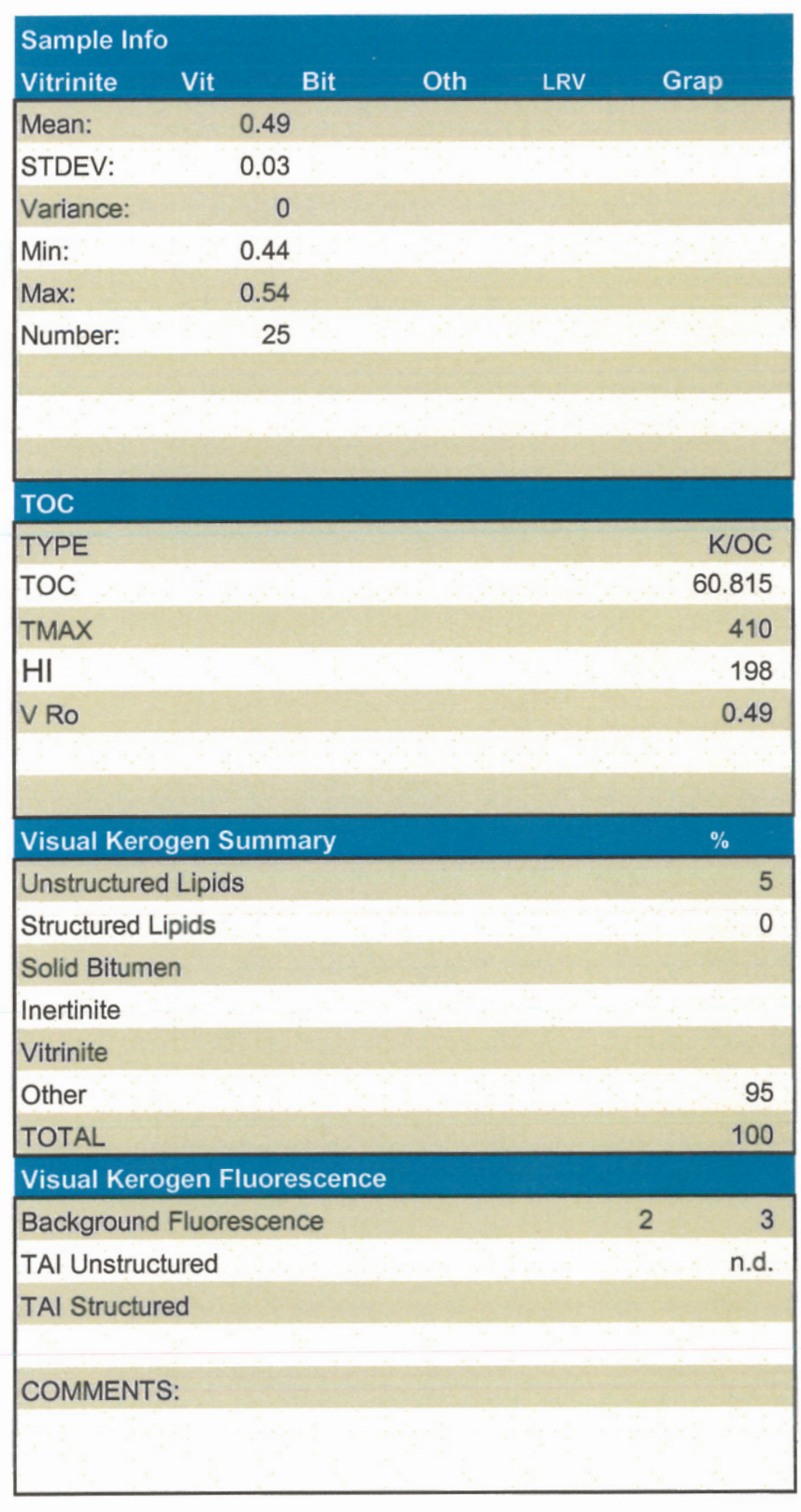

Baseline DGSI - Brazil

55 / 301 Jardim Botânico.

2246120 Rio de Janeiro (RJ) - Brazi

Te-max: + $55.21 / 5377893$ 


\section{Company:}

Country:

Basin:

Lease:

Block:

Field:

Well Name: Latitude:

Longitude:

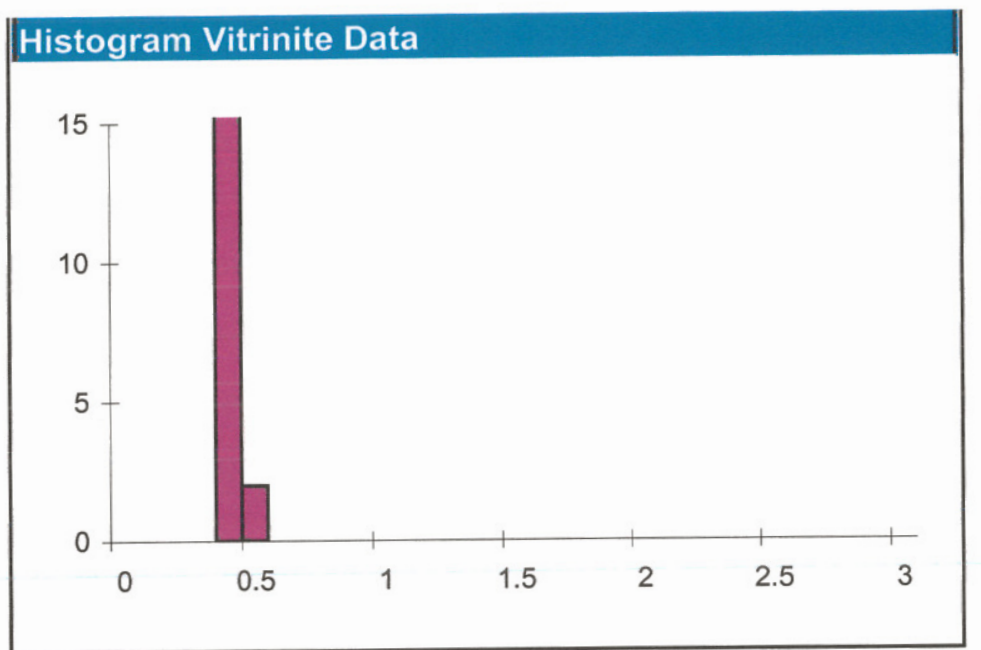

\section{Vitrinite Data:}

L0.42 L0.47

L0.43 L0.48

L0.43 L0.49

L0.44 L0.49

L0.44 L0.501

L0.44 L0.51

L0.45

L0.45

L0.45

L0.45

L0.46

L0.46

L0.46

L0.46

L0.46

L0.46

L0.47

L0.47

L0.47

WINDY FORK SAMPLES HOLITNA OUTCROP
Client ID:

Project \#:

Lab ID:

Sample Type:

Sampling Point:

Formation:

Geologic Age:

Top Depth:

Bottom Depth:

\section{Sample Info}

\section{Vitrinite}

Vit

Bit

Oth

LRV

Grap

Mean:

STDEV:

0.46

Variance:

Min:

0.02

Max:

Number:

0.42

0.51

(1)

TOC

TYPE

TOC

(

TMAX

$\mathrm{HI}$

V Ro

Visual Kerogen Summary

Unstructured Lipids

Structured Lipids

5

Solid Bitumen

Inertinite

Vitrinite

Other

TOTAL

Visual Kerogen Fluorescence

Background Fluorescence

3

TAI Unstructured

TAI Structured

COMMENTS:
Baseline/DGSI - USA

8701 New Trails Drive, The Woodlands, TX 77381-4241

Telephone: 281-681-2200

E-mail: info@baselinedgsi.com

Web Site: $h t t p: / / w w w$.baselinedgsi.com
Baseline DGSI - Brazil

Rua Benjamin Batista 55 / 301 Jardim Botânico.

22461-120 Rio de Janeiro (RJ) - Brazi

Tel//Fax: + 55.21/537 7893

E-mail: ssp@solintec.com.b 
h. BASELINE DGSI VITRINITE REFLECTANCE

Company:
Country:
Basin:
Lease:
Block:
Field:
Well Name: WINDY FORK SAMPLES HOLITNA OUTCROP
Latitude:
Longitude:

\section{Histogram Vitrinite Data}

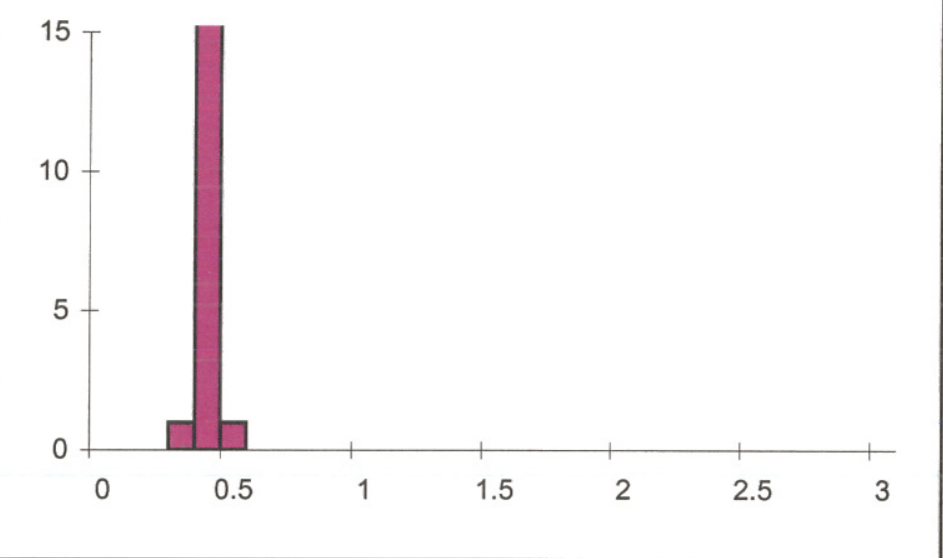

\begin{tabular}{||ll||}
\hline Vitrinite Data: \\
\hline L0.39 & L0.47 \\
$\mathrm{L} 0.41$ & $\mathrm{~L} 0.48$ \\
$\mathrm{~V} 0.41$ & $\mathrm{~L} 0.48$ \\
$\mathrm{~L} 0.42$ & $\mathrm{~L} 0.48$ \\
$\mathrm{~L} 0.42$ & $\mathrm{~L} 0.49$ \\
$\mathrm{~L} 0.42$ & $\mathrm{~L} 0.52$ \\
$\mathrm{~L} 0.42$ & \\
$\mathrm{~L} 0.42$ & \\
$\mathrm{~L} 0.42$ & \\
$\mathrm{~L} 0.43$ & \\
$\mathrm{~L} 0.43$ & \\
$\mathrm{~L} 0.43$ & \\
$\mathrm{~L} 0.44$ & \\
$\mathrm{~L} 0.46$ & \\
$\mathrm{~L} 0.46$ & \\
$\mathrm{~L} 0.46$ & \\
$\mathrm{~L} 0.46$ & \\
$\mathrm{~L} 0.46$ & \\
$\mathrm{~L} 0.47$ & \\
\hline \hline
\end{tabular}

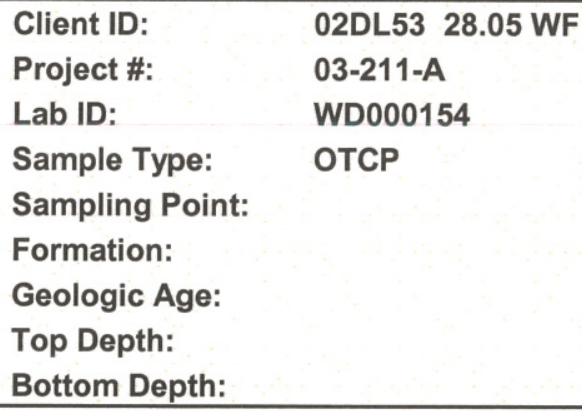

Client ID:

Project \#:

02DL53 28.05 WF

Lab ID:

03-211-A

Sample Type:

WD000154

Sampling Point:

Formation:

Geologic Age:

Top Depth:

Bottom Depth:

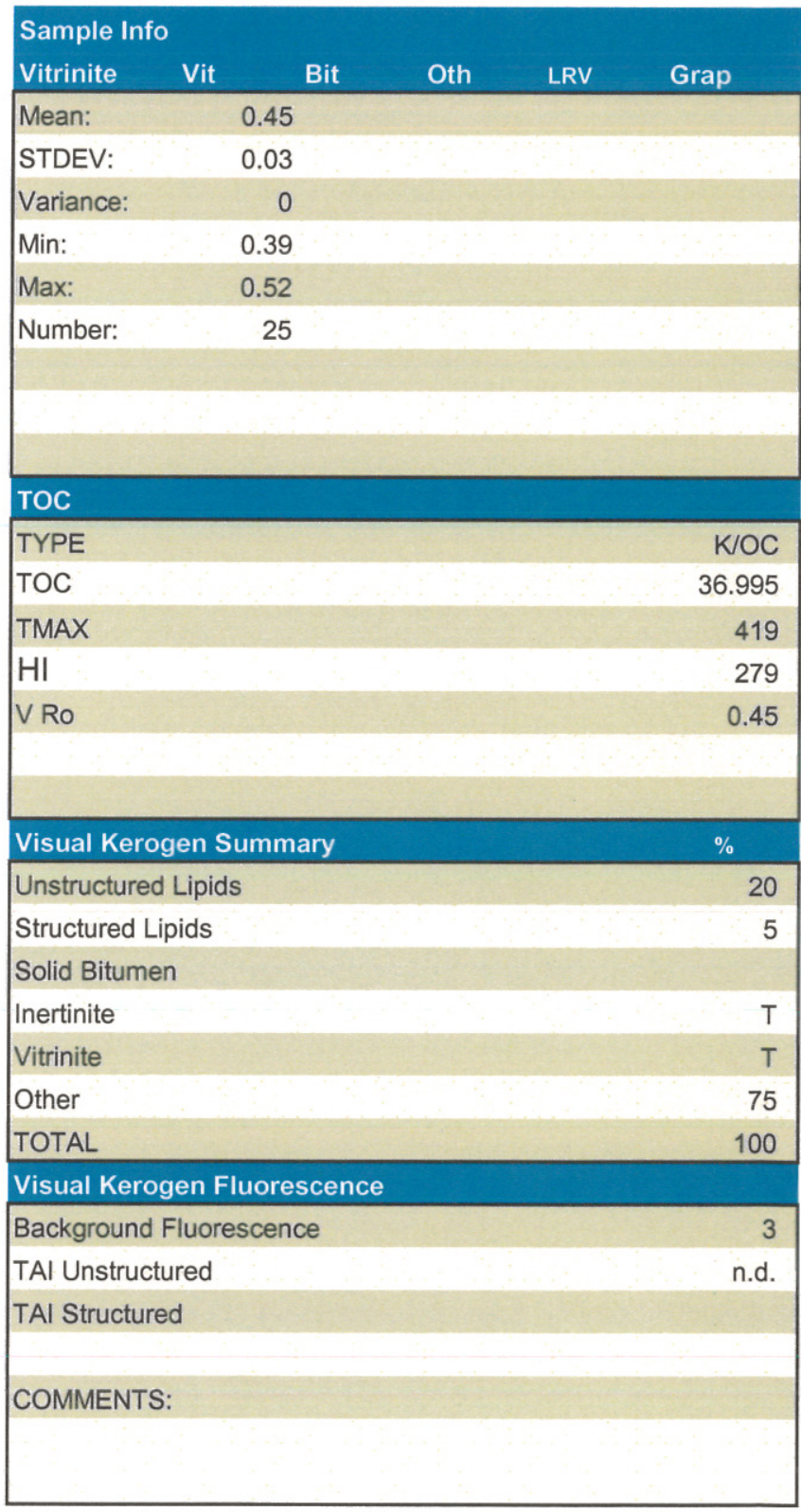

Baseline/DGSI - USA

8701 New Trails Drive. The Woodlands, TX 77381-4241

Telephone: $281-681-2200$

E-mail: info $Q$ baselinedgsicom

Web Site: http://www baselinedgsi.com
Baseline DGSI - Brazil

Rua Benjamin Batista 55 / 301 Jardim Botânico.

22461-120 Rio de Janeiro (RJ) - Brazil

Tel/Fax: + 55.21 / 5377893

E-mail: ssp@solintec.comb 


\section{BASELINE DCSI VITRINITE REFLECTANCE}

Company:

Country:

Basin:

Lease:

Block:

Field:

Well Name:

Latitude:

Longitude:

\section{Histogram Vitrinite Data}

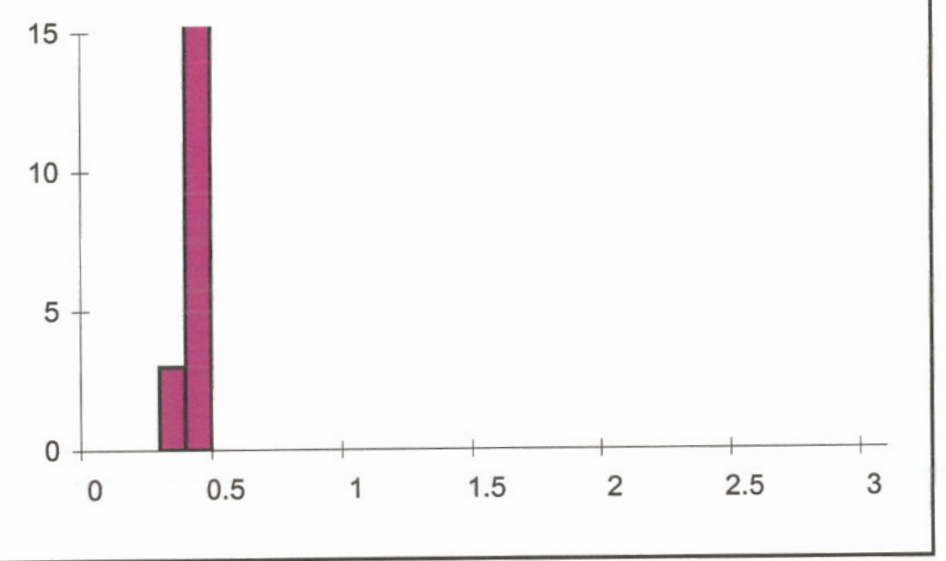

\section{Vitrinite Data:}

\section{L0.34 L0.46}

L0.38 L0.47

L0.38 L0.47

L0.401 L0.47

L0.41 L0.48

L0.41 L0.49

L0.41

L0.44

L0.44

L0.44

L0.44

L0.45

L0.45

L0.45

L0.45

L0.45

L0.45

L0.46

L0.46
Client ID:

Project \#:

Lab ID:

Sample Type:

Sampling Point:

Formation:

Geologic Age:

Top Depth:

Bottom Depth:

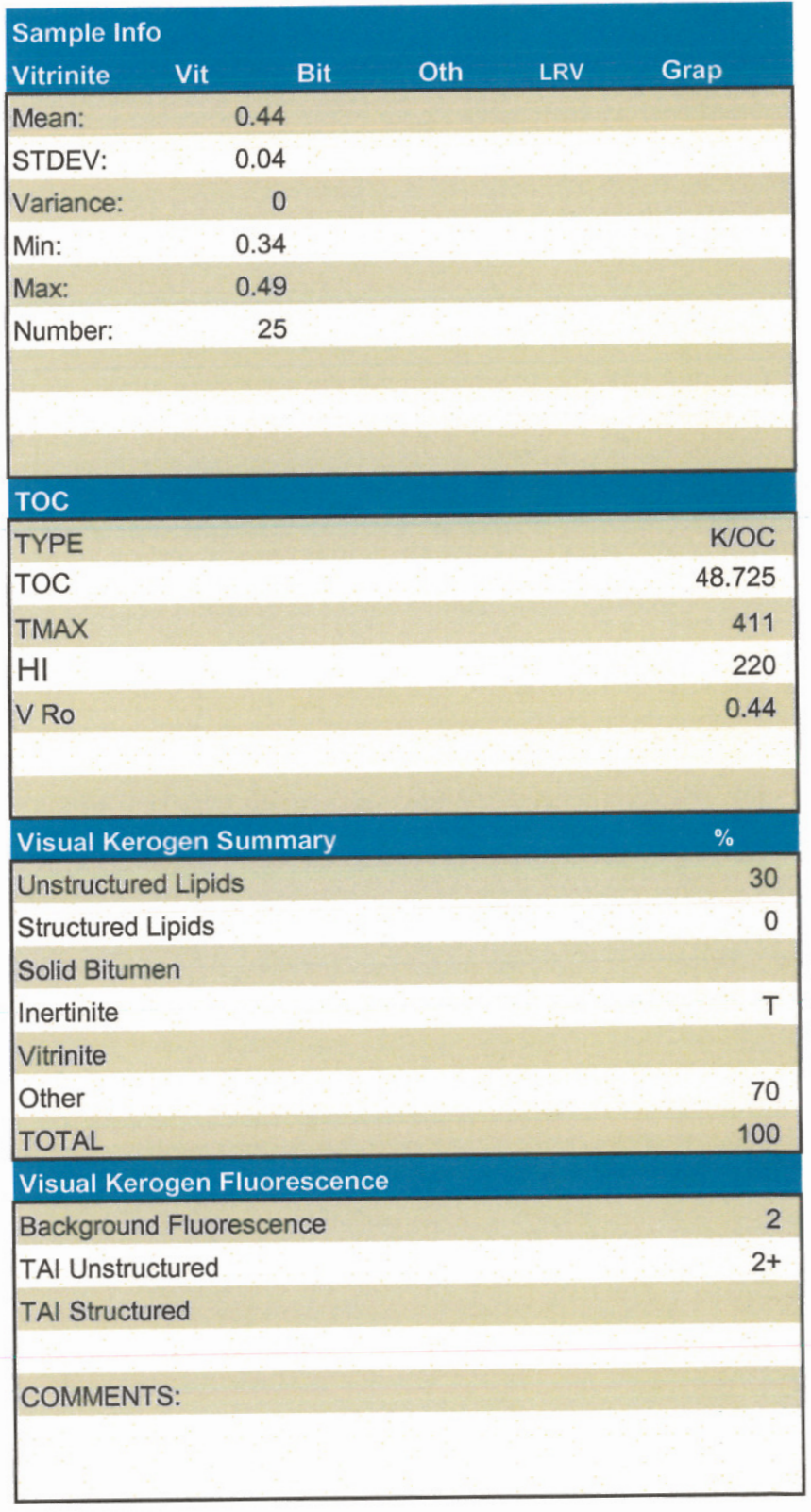

02DL53 34 WF

03-211-A

WD000157

OTCP 
VITRINITE REFLECTANCE

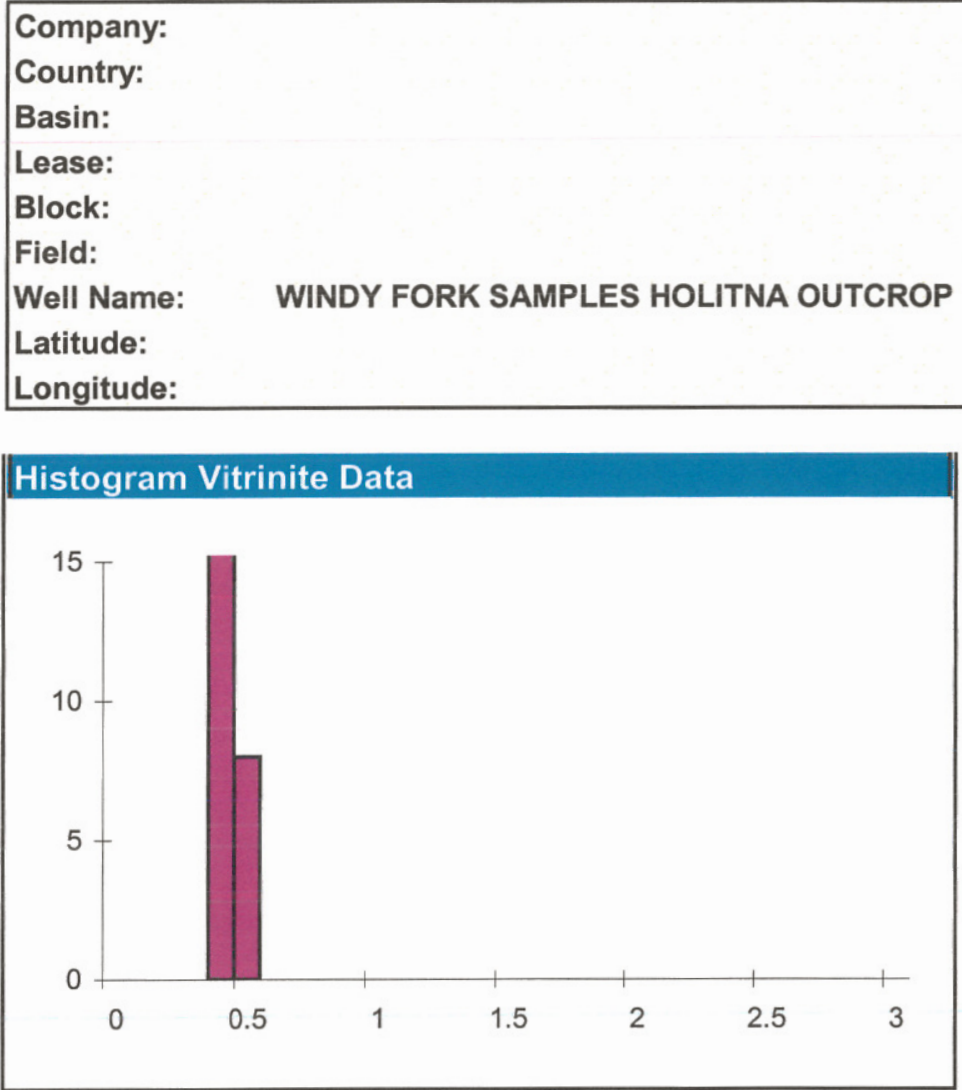

\begin{tabular}{||ll||}
\hline Vitrinite Data: \\
\hline $\mathrm{L} 0.42$ & $\mathrm{~L} 0.51$ \\
$\mathrm{~L} 0.42$ & $\mathrm{~L} 0.51$ \\
$\mathrm{~L} 0.44$ & $\mathrm{~L} 0.52$ \\
$\mathrm{~L} 0.44$ & $\mathrm{~L} 0.52$ \\
$\mathrm{~L} 0.45$ & $\mathrm{~L} 0.53$ \\
$\mathrm{~L} 0.45$ & $\mathrm{~L} 0.55$ \\
$\mathrm{~L} 0.45$ & \\
$\mathrm{~L} 0.46$ & \\
$\mathrm{~L} 0.47$ & \\
$\mathrm{~L} 0.47$ & \\
$\mathrm{~L} 0.47$ & \\
$\mathrm{~L} 0.48$ & \\
$\mathrm{~L} 0.48$ & \\
$\mathrm{~L} 0.48$ & \\
$\mathrm{~L} 0.49$ & \\
$\mathrm{~L} 0.49$ & \\
$\mathrm{~L} 0.49$ & \\
$\mathrm{~L} 0.501$ & \\
$\mathrm{~L} 0.501$ & \\
\hline
\end{tabular}

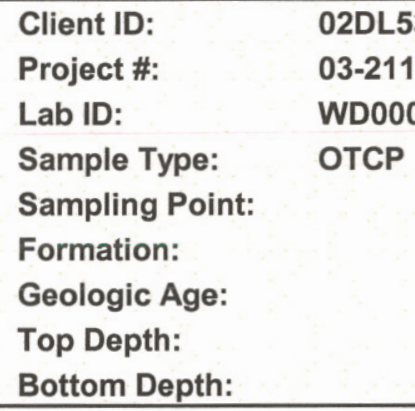

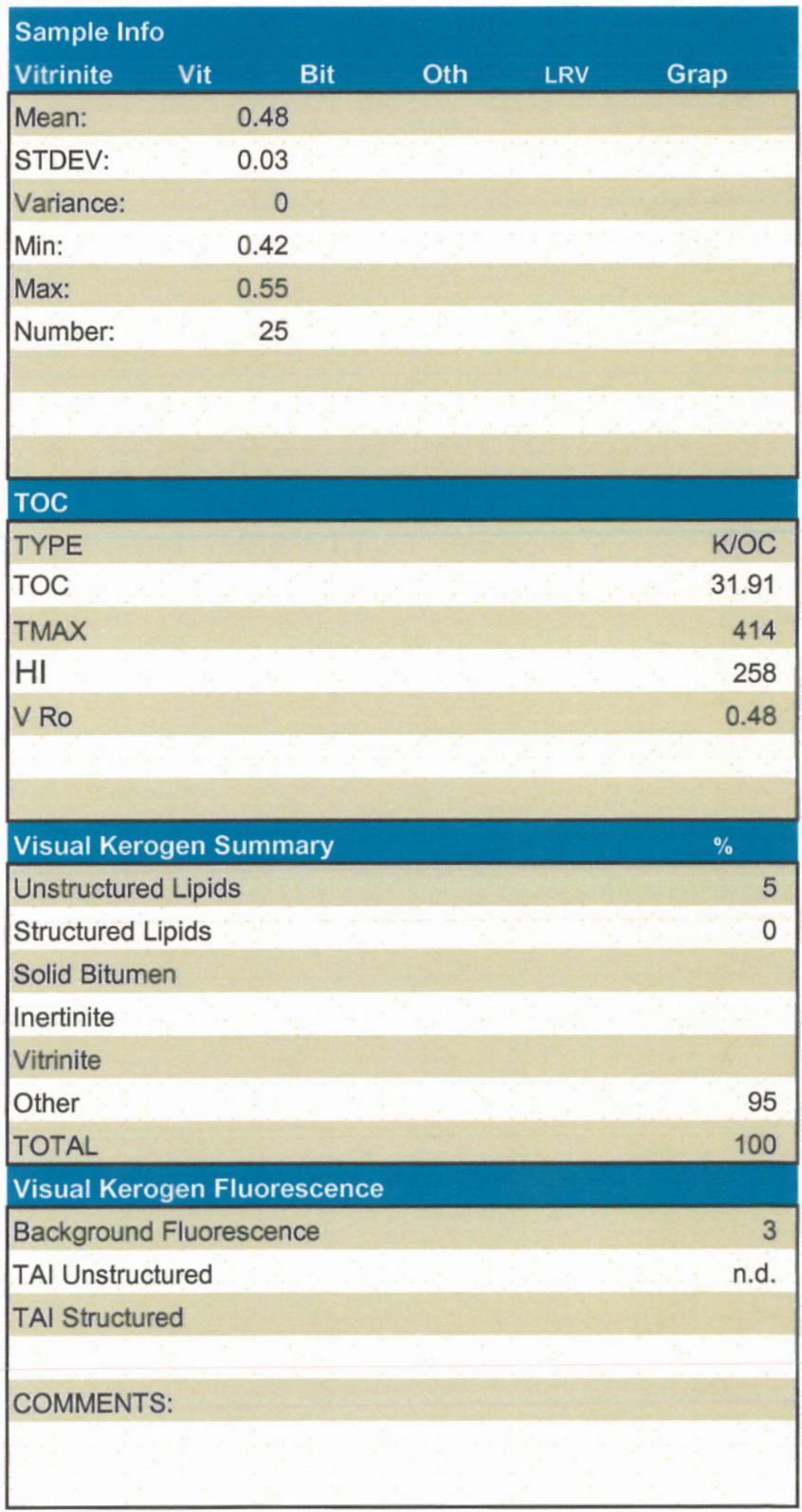




\section{BASELINE DGSI VITRINITE REFLECTANCE}

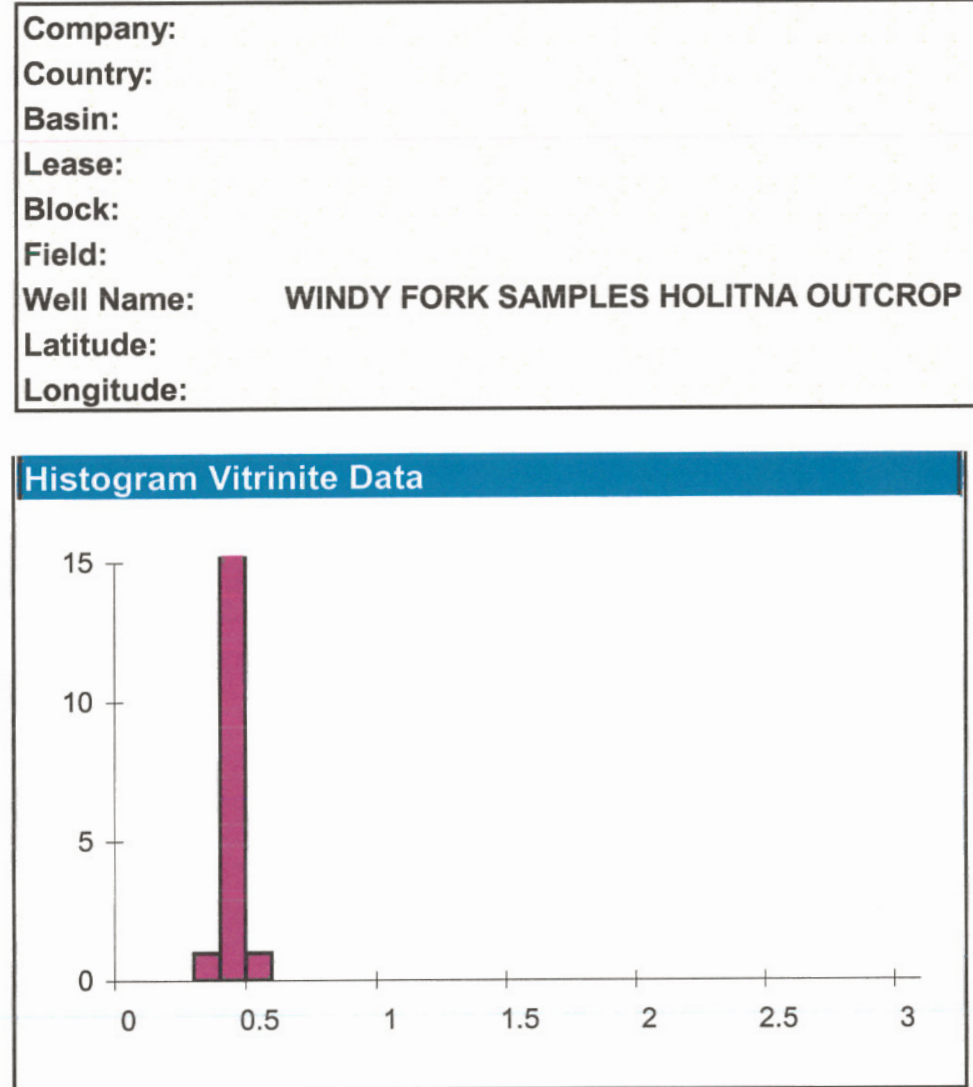

\begin{tabular}{||ll||}
\hline Vitrinite Data: \\
\hline $\mathrm{L} 0.39$ & $\mathrm{~L} 0.46$ \\
$\mathrm{~L} 0.41$ & $\mathrm{~L} 0.46$ \\
$\mathrm{~L} 0.41$ & $\mathrm{~L} 0.46$ \\
$\mathrm{~L} 0.42$ & $\mathrm{~L} 0.46$ \\
$\mathrm{~L} 0.42$ & $\mathrm{~L} 0.47$ \\
$\mathrm{~L} 0.42$ & $\mathrm{~L} 0.501$ \\
$\mathrm{~L} 0.42$ & \\
$\mathrm{~L} 0.42$ & \\
$\mathrm{~L} 0.42$ & \\
$\mathrm{~L} 0.42$ & \\
$\mathrm{~L} 0.43$ & \\
$\mathrm{~L} 0.44$ & \\
$\mathrm{~L} 0.44$ & \\
$\mathrm{~L} 0.45$ & \\
$\mathrm{~L} 0.45$ & \\
$\mathrm{~L} 0.45$ & \\
$\mathrm{~L} 0.45$ & \\
$\mathrm{~L} 0.45$ & \\
$\mathrm{~L} 0.45$ & \\
\hline
\end{tabular}

Client ID:

Project \#:

Lab ID:

Sample Type:

Sampling Point:

Formation:

Geologic Age:

Top Depth:

Bottom Depth:

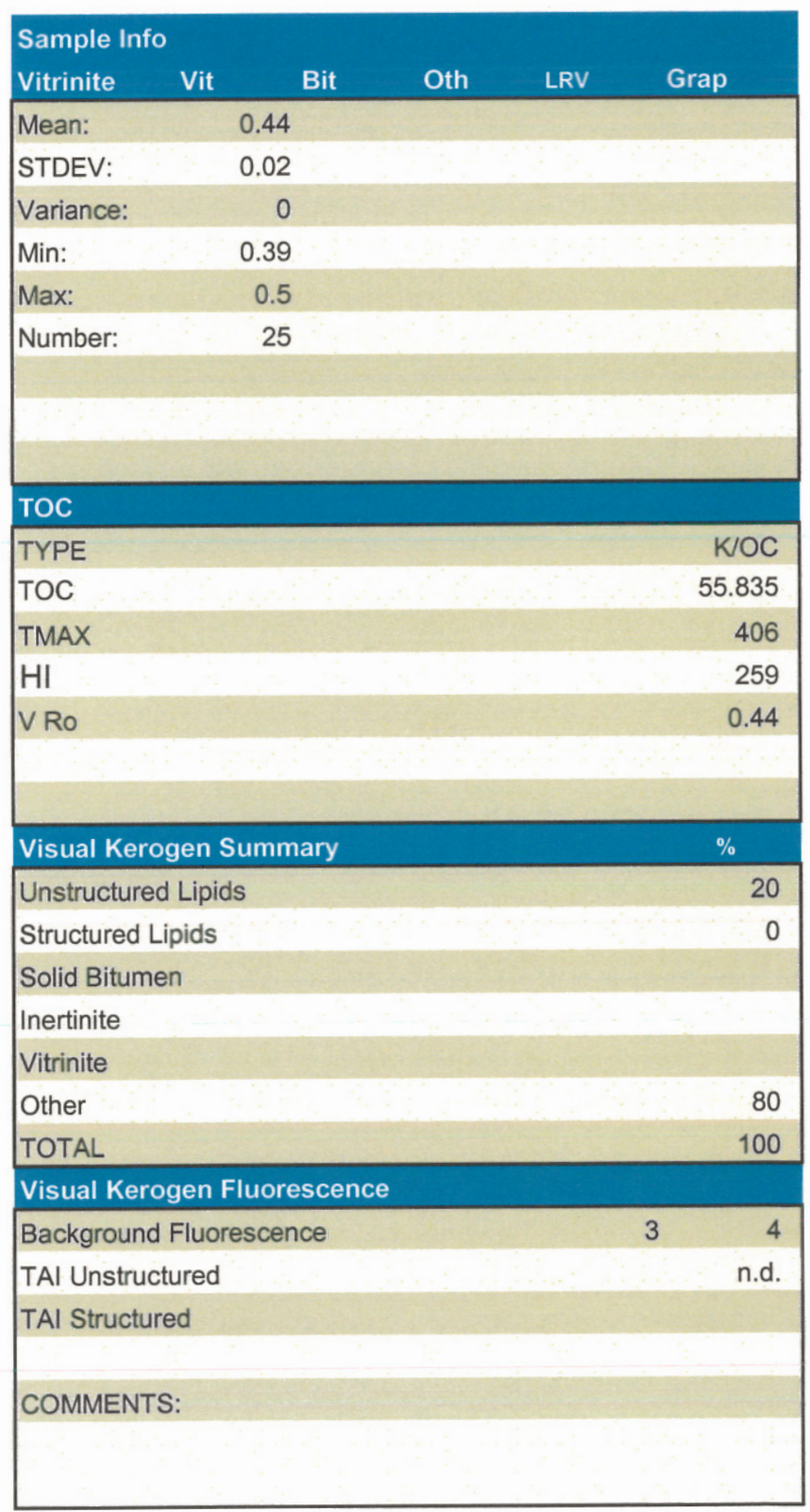

02DL53 42 WF

03-211-A

WD000162

OTCP
Baselline/DGSI - USA

8701 New Trails Dive, The Woodlands. TX 77381-424

Telephone: 281-681-2200

E-mail: info@baselinedgsi.com

E-mail: infoabaselinedgsi.com 


\section{BASELINE DGSI VITRINITE REFLECTANCE}

Company:
Country:
Basin:
Lease:
Block:
Field:
Well Name: WINDY FORK SAMPLES HOLITNA OUTCROP
Latitude:
Longitude:

\section{Histogram Vitrinite Data}

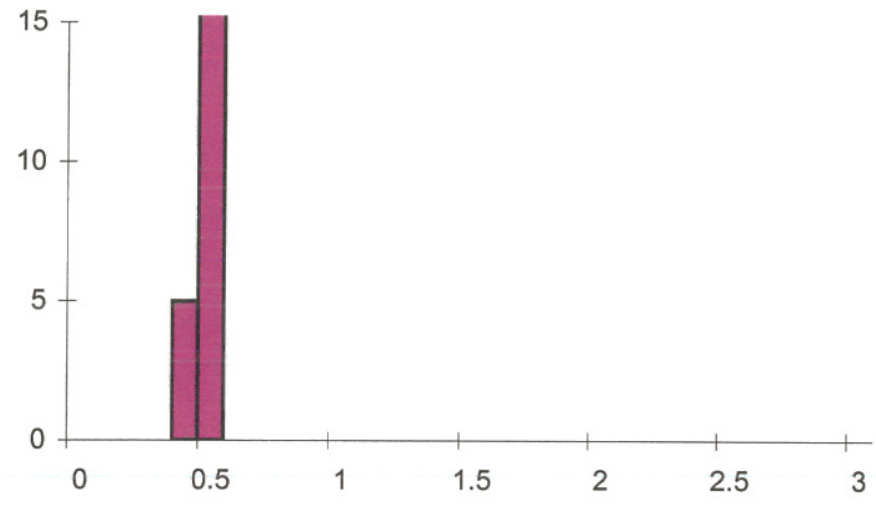

\section{Client ID: \\ Project \#: \\ Lab ID:}

Sample Type:

Sampling Point:

Formation:

Geologic Age:

Top Depth:

Bottom Depth:

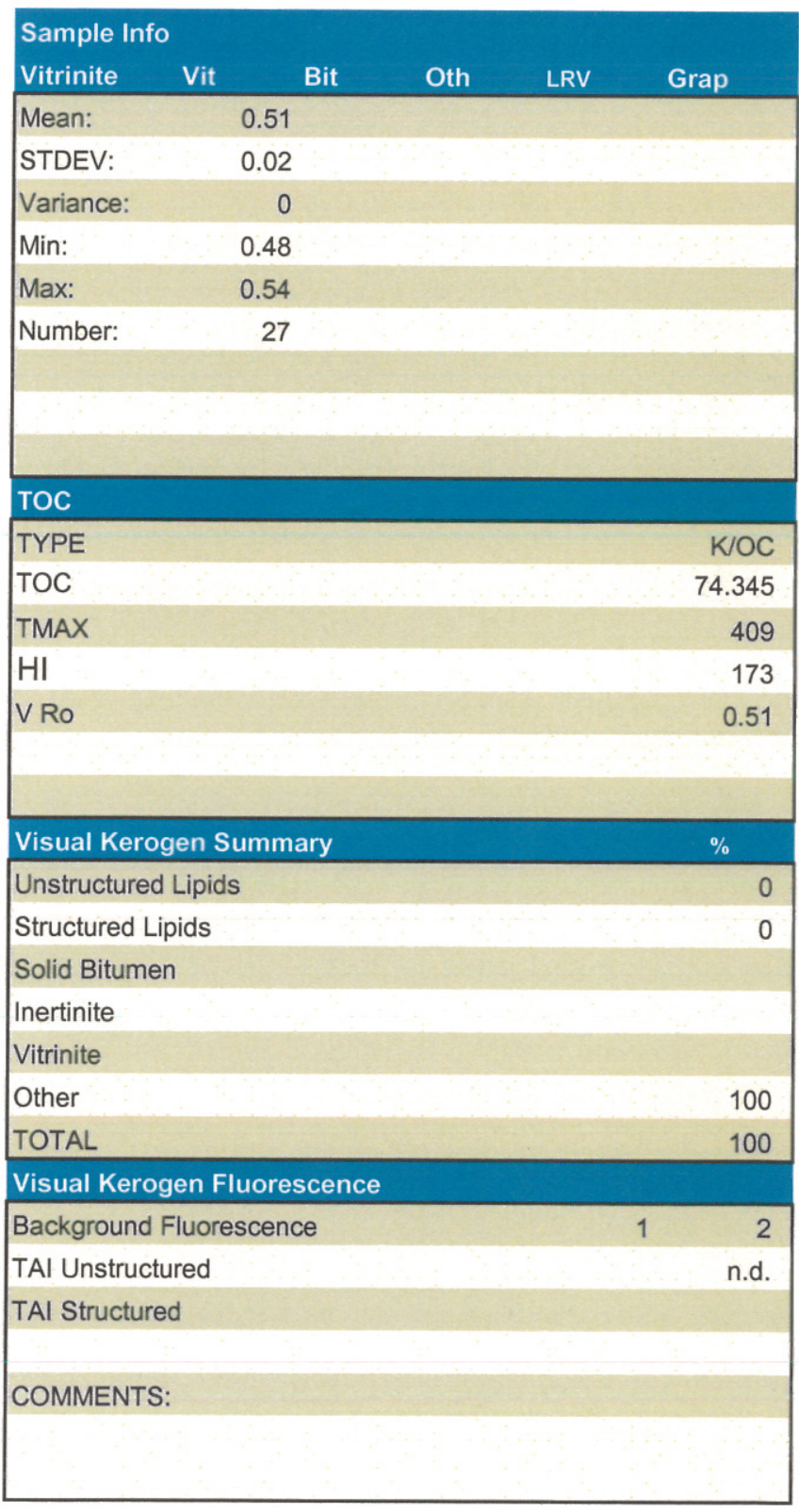

02DL53 44 WF

03-211-A

WD000163

OTCP
Baseline/DGSI - USA

8701 New Trails Drive. The Woodlands, TX 77381-424

Telephone: $281-681-2200$

Facsimile: $281-681-0326$

E-mail: info@baselinedgsi.com

Web Site: http://www.baselinedgsi.com

\begin{tabular}{||ll||}
\hline Vitrinite Data: \\
L0.48 & L0.52 \\
L0.49 & L0.52 \\
L0.49 & L0.52 \\
$L 0.49$ & L0.53 \\
L0.49 & L0.53 \\
$L 0.501$ & L0.54 \\
$L 0.501$ & L0.54 \\
$L 0.501$ & L0.54 \\
$L 0.501$ & \\
$L 0.501$ & \\
$L 0.501$ & \\
$L 0.501$ & \\
$L 0.501$ & \\
$L 0.51$ & \\
$L 0.51$ & \\
$L 0.51$ & \\
$L 0.51$ & \\
$L 0.52$ & \\
$L 0.52$ &
\end{tabular}

Baseline DGSI - Brazil

Rua Benjamin Batista 55 / 301 Jardim Botânico.

22461-120 Rio de Janeiro (RJ) - Brazil

Tel/Fax: + 55.21 / 5377893

E-mail: ssp@solintec.com.b 


\section{hNEASELINE DESI VITRINITE REFLECTANCE}

\section{Company:}

Country:

Basin:

Lease:

Block:

Field:

Well Name:

Latitude:

Longitude:

\section{Histogram Vitrinite Data}

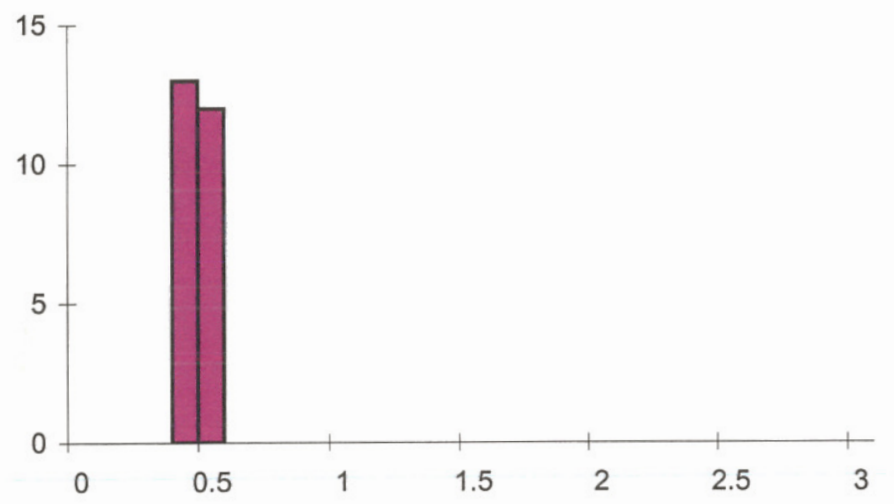

\section{Vitrinite Data:}

\section{L0.43 L0.51}

L0.44 L0.52

L0.44 L0.52

L0.45 L0.52

L0.46 L0.53

L0.46 L0.54

L0.47

L 0.47

L0.47

L0.47

L0.47

L0.49

L0.49

L0.501

L0.501

L0.501

L0.51

L0.51

L 0.51

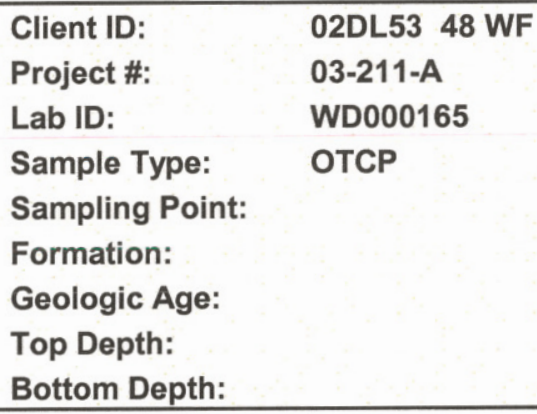

Client ID:

Project \#:

Lab ID:

Sample Type:

Sampling Point:

Formation:

Geologic Age:

Top Depth:

Bottom Depth:

ОTCP

\section{Sample Info}

Vitrinite

Vit

Bit

Oth

LRV

Grap

\begin{tabular}{lr}
\hline Mean: & 0.49 \\
\hline STDEV: & 0.03 \\
\hline Variance: & 0 \\
Min: & 0.43 \\
Max: & 0.54 \\
Number: & 25
\end{tabular}

\section{TOC}

TYPE

TOC

TMAX

HI

$\checkmark$ Ro

0.49

Visual Kerogen Summary

Unstructured Lipids

Structured Lipids

Solid Bitumen

Inertinite

Vitrinite

Other

TOTAL

Visual Kerogen Fluorescence

Background Fluorescence

TAI Unstructured

TAI Structured

COMMENTS:
Baseline DGSI - Brazil

Rua Benjamin Batista 55 / 301 Jardim Botânico.

22461-120 Rio de Janeiro (RJ) - Braz

Tel/Fax: + $55.21 / 5377893$ 


\section{h. BASELINE DGSI VITRINITE REFLECTANCE}

Company:
Country:
Basin:
Lease:
Block:
Field:
Well Name: WINDY FORK SAMPLES HOLITNA OUTCROP
Latitude:
Longitude:

\section{Histogram Vitrinite Data}

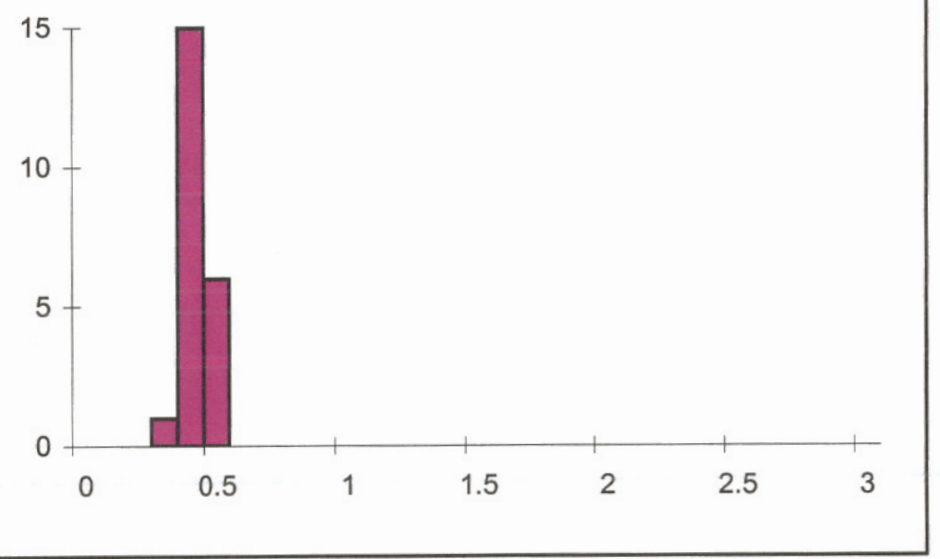

\begin{tabular}{||ll||}
\hline Vitrinite Data: \\
\hline$L 0.39$ & L0.53 \\
$L 0.42$ & L0.53 \\
$L 0.42$ & L0.53 \\
$L 0.42$ & \\
$L 0.43$ & \\
$L 0.43$ & \\
$L 0.43$ & \\
$L 0.44$ & \\
$L 0.44$ & \\
$L 0.45$ & \\
$L 0.45$ & \\
$L 0.46$ & \\
$L 0.47$ & \\
$L 0.48$ & \\
$L 0.49$ & \\
$L 0.49$ & \\
$L 0.501$ & \\
$L 0.52$ & \\
$L 0.53$ & \\
\hline
\end{tabular}

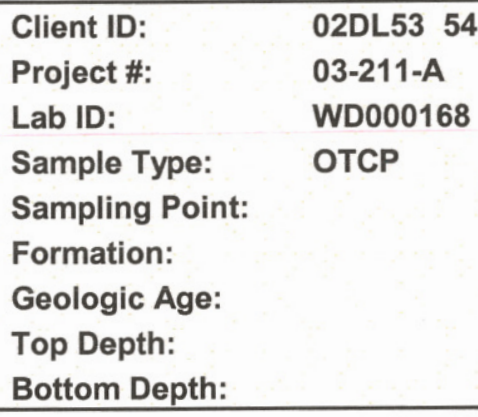

03-211-A

WD000168

ОTCP

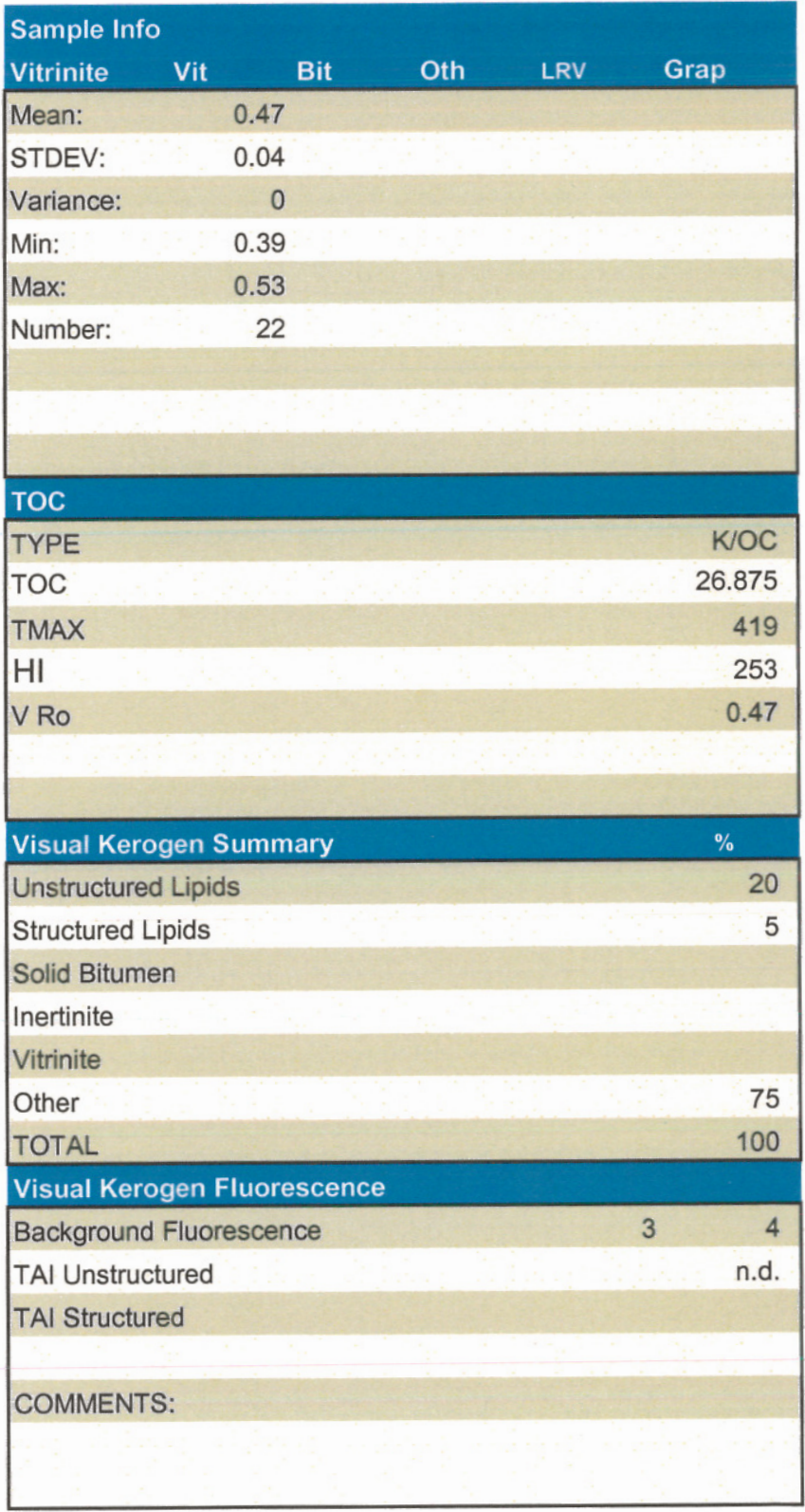




\section{BASELINE DCSIVITRINITE REFLECTANCE}

\section{Company:}

Country:

Basin:

Lease:

Block:

Field:

Well Name:

Latitude:

Longitude:

\section{Histogram Vitrinite Data}

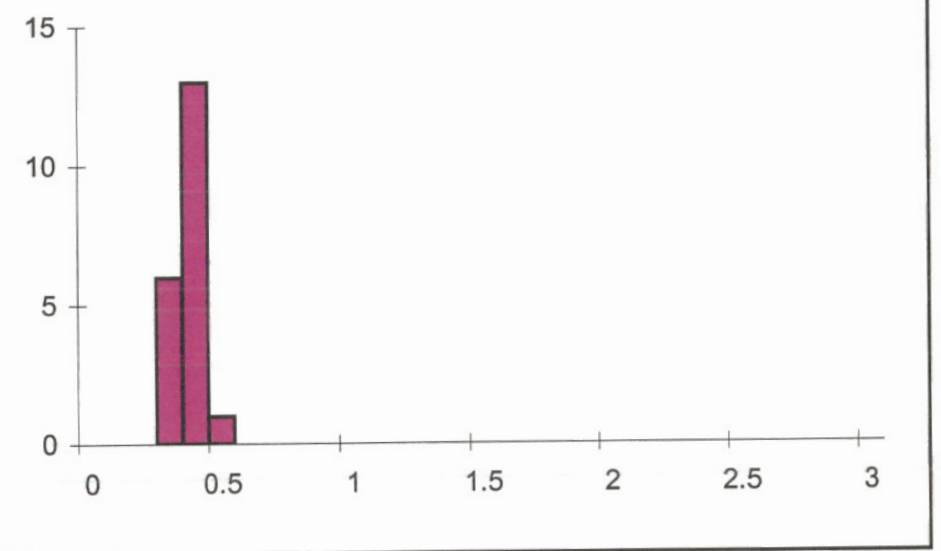

\section{Vitrinite Data:}

\section{L0.32 L0.51}

L0.36

L 0.37

L0.38

L0.38

L0.39

L0.401

L0.41

L0.42

L0.42

L0.43

L0.43

L0.43

L0.44

L0.45

L0.45

L0.45

L0.46

LL 0.47
Client ID:

Project \#:

Lab ID:

Sample Type:

Sampling Point:

Formation:

Geologic Age:

Top Depth:

Bottom Depth:

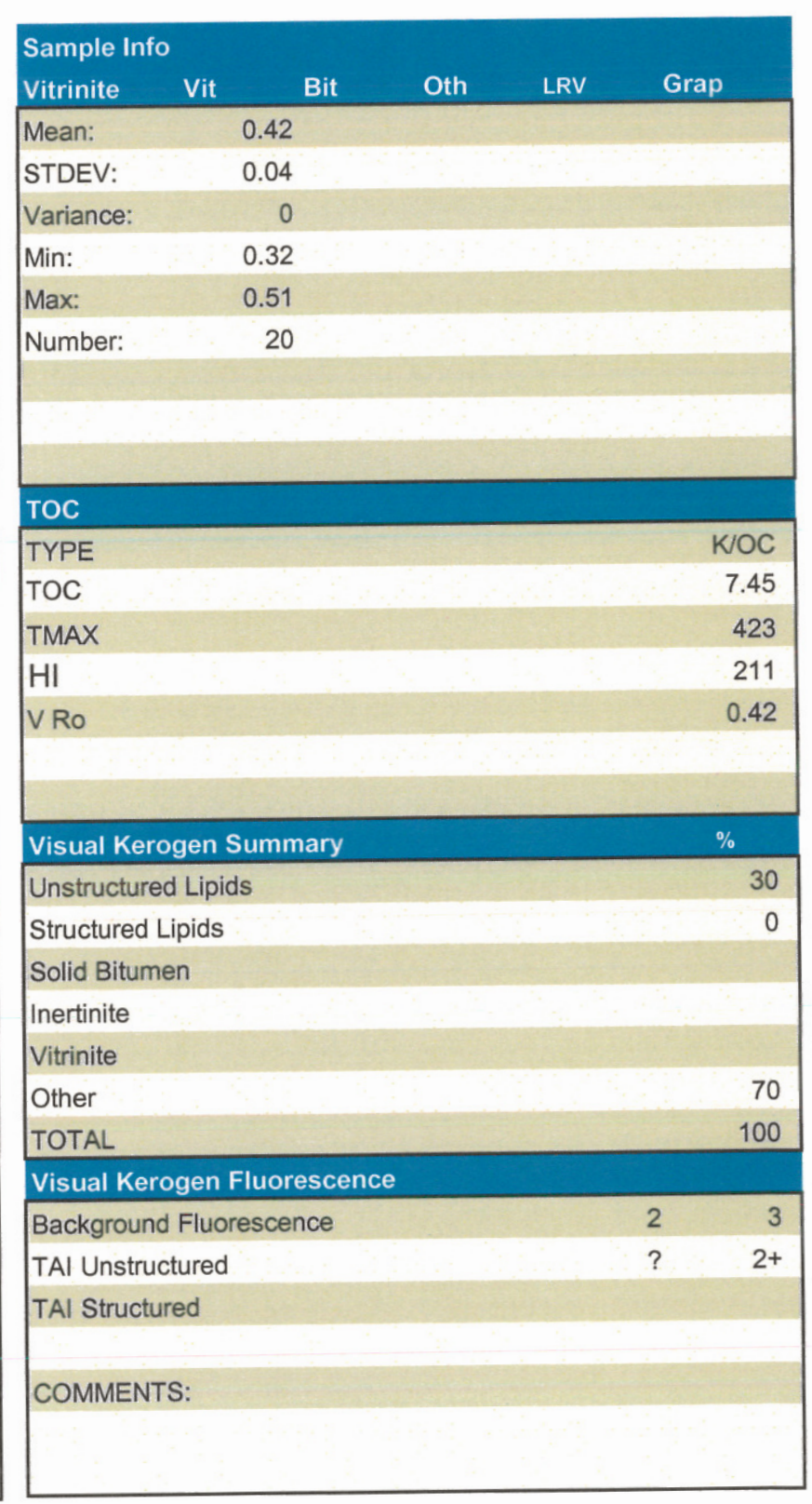




\section{h. BASELINE DGSI VITRINITE REFLECTANCE}

\begin{tabular}{|lll|}
\hline Company: & Client ID: & 02DL53 62 WF \\
Country: & Project \#: & 03-211-A \\
Basin: & Lab ID: & WD000172 \\
Lease: & Sample Type: & OTCP \\
Block: & Sampling Point: & \\
Field: & WINDY FORK SAMPLES HOLITNA OUTCROP & Geologic Age: \\
Well Name: & Topmation: \\
Latitude: & & Top Depth: \\
Longitude: & Bottom Depth: \\
\hline
\end{tabular}

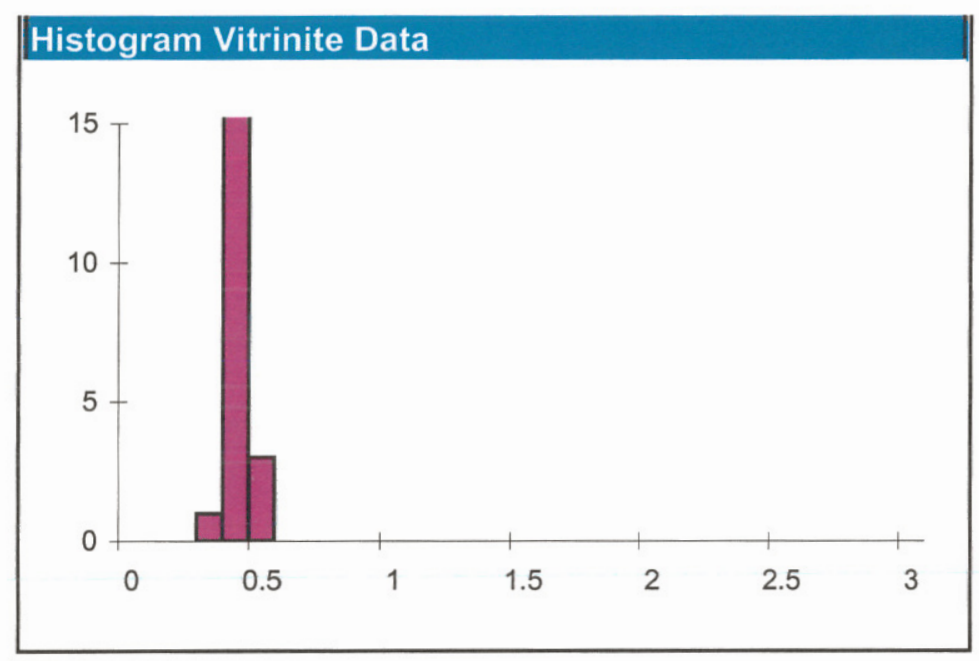

\begin{tabular}{||ll||}
\hline Vitrinite Data: \\
\hline $\mathrm{L} 0.39$ & $\mathrm{~L} 0.47$ \\
$\mathrm{~L} 0.401$ & $\mathrm{~L} 0.47$ \\
$\mathrm{~L} 0.401$ & $\mathrm{~L} 0.48$ \\
$\mathrm{~L} 0.41$ & $\mathrm{~L} 0.501$ \\
$\mathrm{~L} 0.41$ & $\mathrm{~L} 0.501$ \\
$\mathrm{~L} 0.41$ & $\mathrm{~L} 0.501$ \\
$\mathrm{~L} 0.42$ & \\
$\mathrm{~L} 0.43$ & \\
$\mathrm{~L} 0.43$ & \\
$\mathrm{~L} 0.43$ & \\
$\mathrm{~L} 0.44$ & \\
$\mathrm{~L} 0.45$ & \\
$\mathrm{~L} 0.45$ & \\
$\mathrm{~L} 0.45$ & \\
$\mathrm{~L} 0.45$ & \\
$\mathrm{~L} 0.45$ & \\
$\mathrm{~L} 0.45$ & \\
$\mathrm{~L} 0.46$ & \\
$\mathrm{~L} 0.47$ & \\
\hline
\end{tabular}

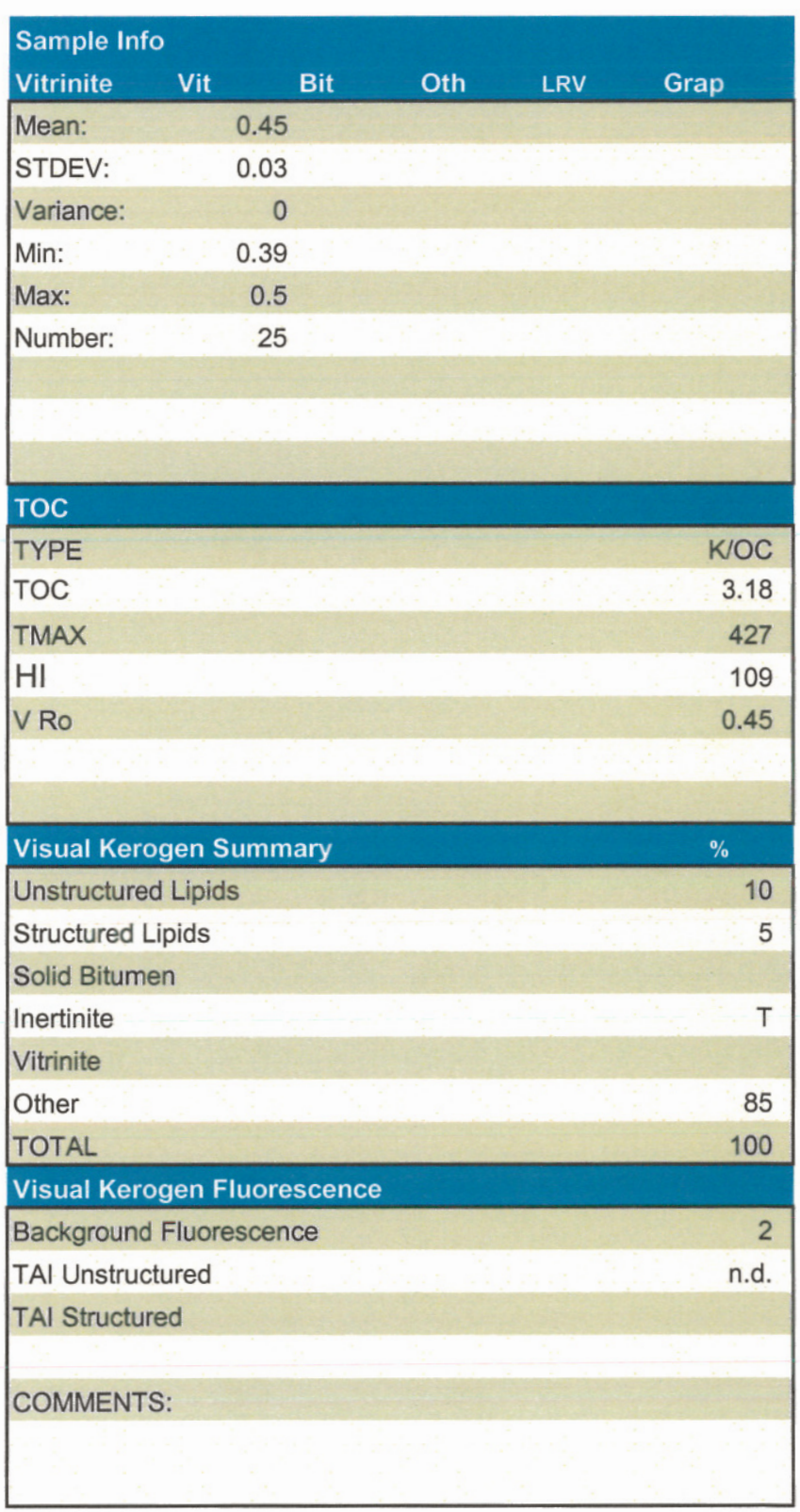

Baseline DGSI - Brazil

Rua Benjamin Batista 55 / 301 Jardim Botânico. $22461-120$ Rio de Janeiro (RJ) - Brazil Tel/Fax: + $55.21 / 5377893$ 


\section{W BASELINE DCSIVITRINITE REFLECTANCE}

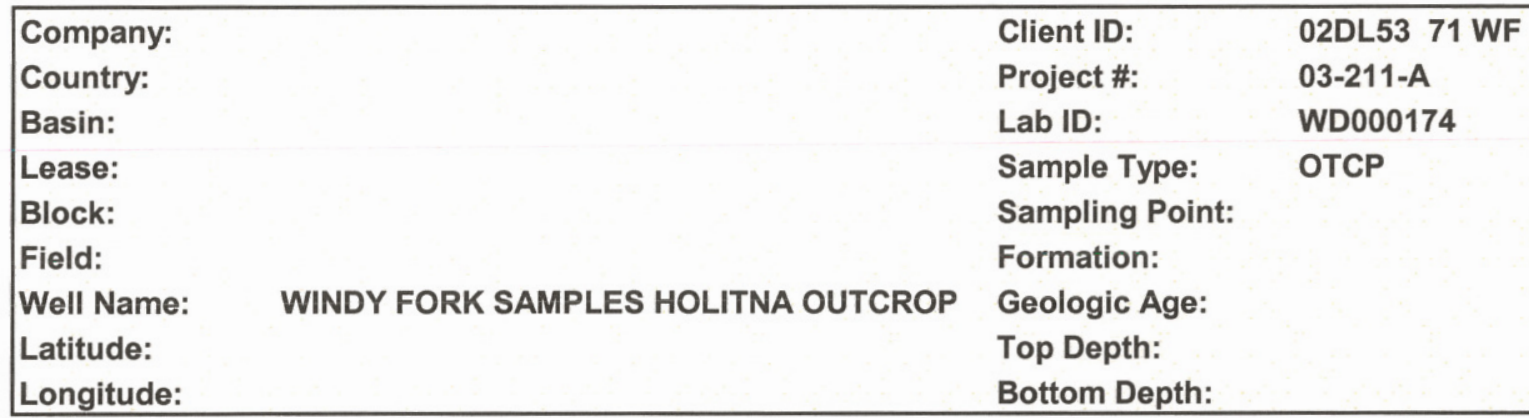

Field:

Well Name: $\quad$ WINDY FORK SAMPLES HOLITNA OUTCROP Latitude:

Longitude:

Client ID:

Project \#:

Lab ID:

Sample Type:

Sampling Point:

Formation:

Geologic Age:

Top Depth:

Bottom Depth:

\section{DL53 71 WF}

03-211-A

WD000174

OTCP

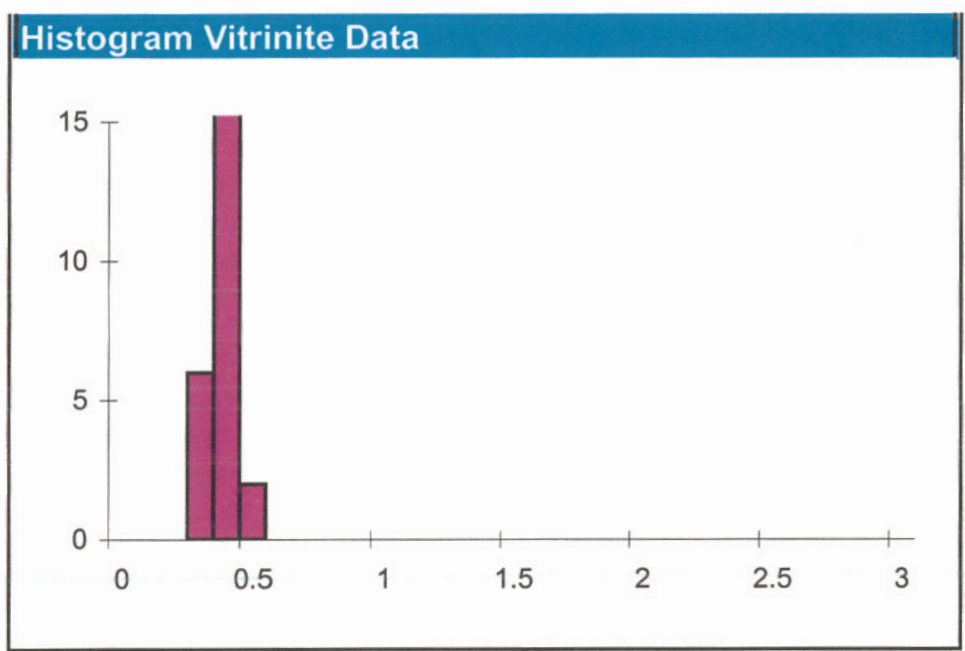

\begin{tabular}{||ll||}
\hline Vitrinite Data: \\
\hline $\mathrm{L} 0.34$ & $\mathrm{~L} 0.48$ \\
$\mathrm{~L} 0.34$ & $\mathrm{~L} 0.48$ \\
$\mathrm{~L} 0.35$ & $\mathrm{~L} 0.49$ \\
$\mathrm{~L} 0.35$ & $\mathrm{~L} 0.49$ \\
$\mathrm{~L} 0.36$ & $\mathrm{~L} 0.501$ \\
$\mathrm{~L} 0.39$ & $\mathrm{~L} 0.51$ \\
$\mathrm{~L} 0.401$ & \\
$\mathrm{~L} 0.41$ & \\
$\mathrm{~L} 0.41$ & \\
$\mathrm{~L} 0.42$ & \\
$\mathrm{~L} 0.42$ & \\
$\mathrm{~L} 0.42$ & \\
$\mathrm{~L} 0.43$ & \\
$\mathrm{~L} 0.43$ & \\
$\mathrm{~L} 0.45$ & \\
$\mathrm{~L} 0.45$ & \\
$\mathrm{~L} 0.45$ & \\
$\mathrm{~L} 0.47$ & \\
$\mathrm{~L} 0.47$ & \\
\hline
\end{tabular}

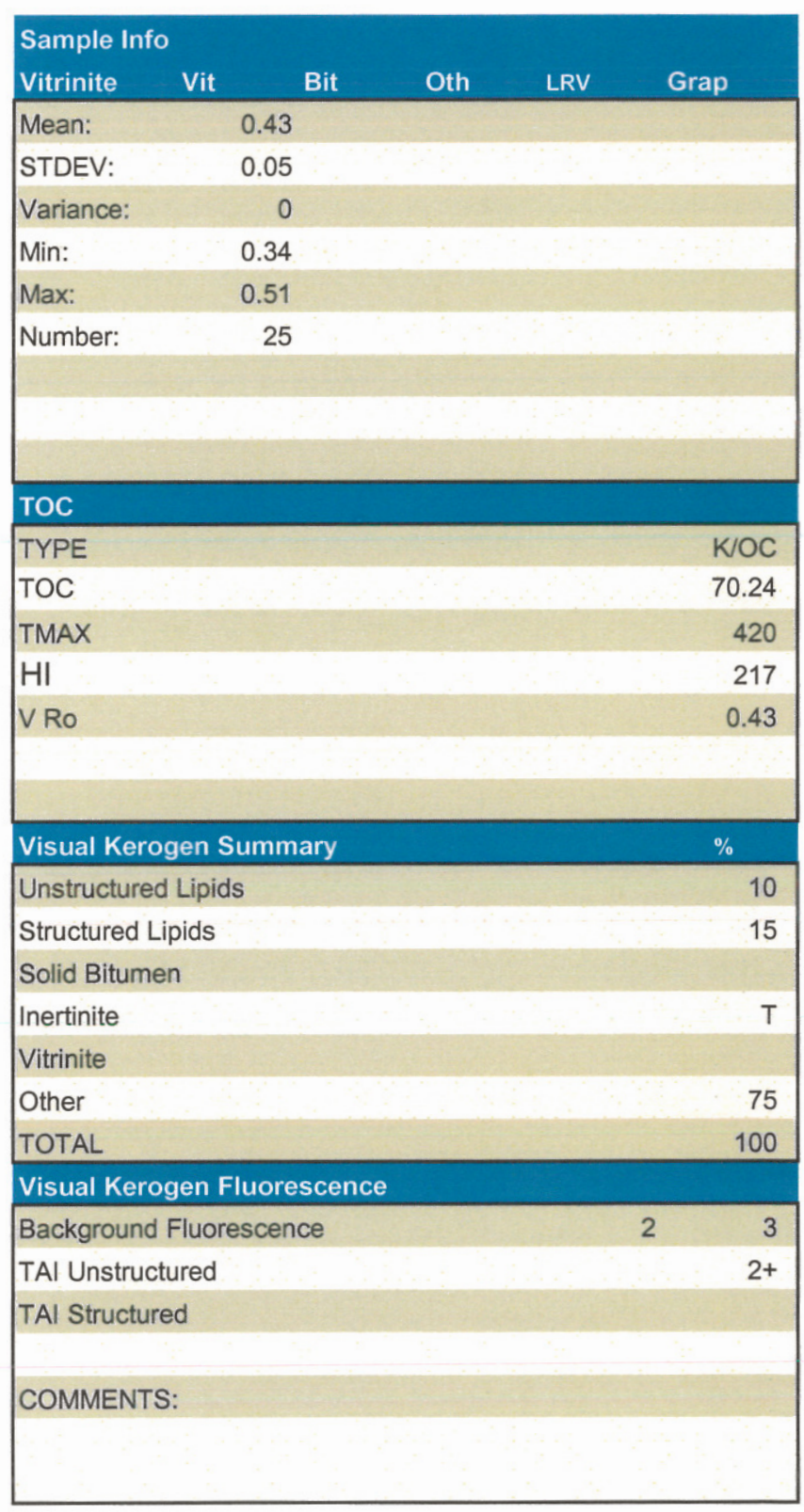




\section{BASELINE DCSI VITRINITE REFLETANCE}

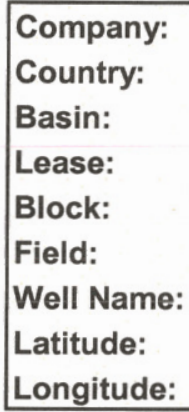

\section{Histogram Vitrinite Data}

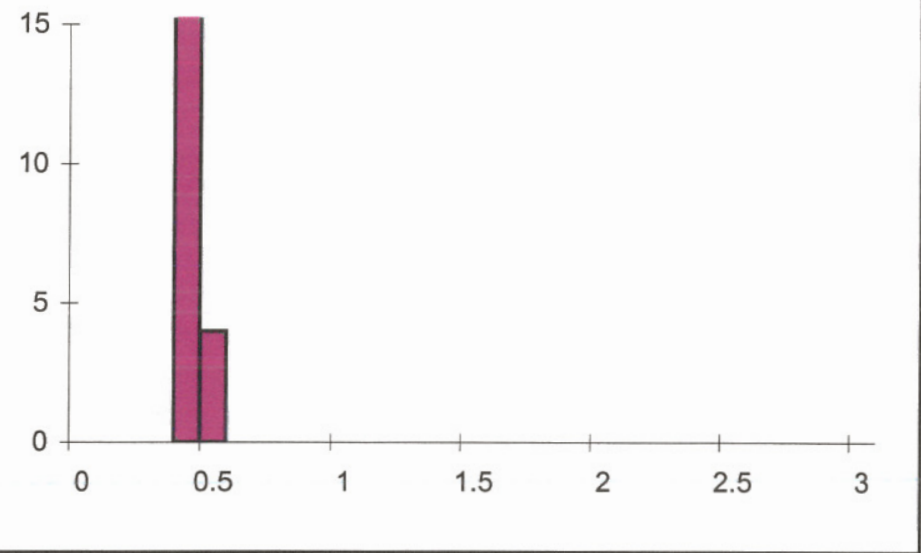

\section{Vitrinite Data:}

\section{L0.401 L0.49}

L0.42 L0.49

L0.43 L0.501

L0.44 L0.501

L0.45 L0.51

L0.45 L0.53

L0.45

L0.46

L0.46

L0.46

L0.46

L0.46

L0.46

L0.47

L0.47

L0.48

L0.48

L0.48

L0.49

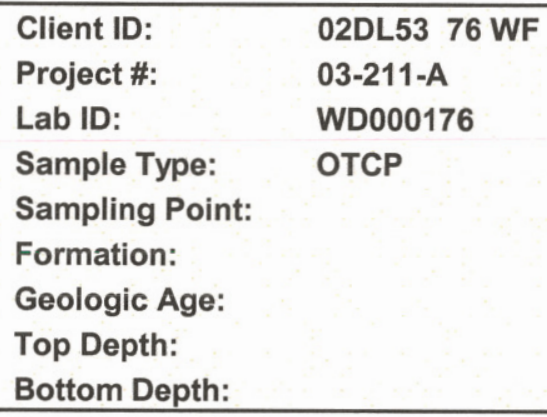

Client ID:

Project \#:

Lab ID:

02DL53 76 WF

03-211-A

Sample Type:

WD000176

Sampling Point:

Formation:

Geologic Age:

Top Depth:

Bottom Depth:

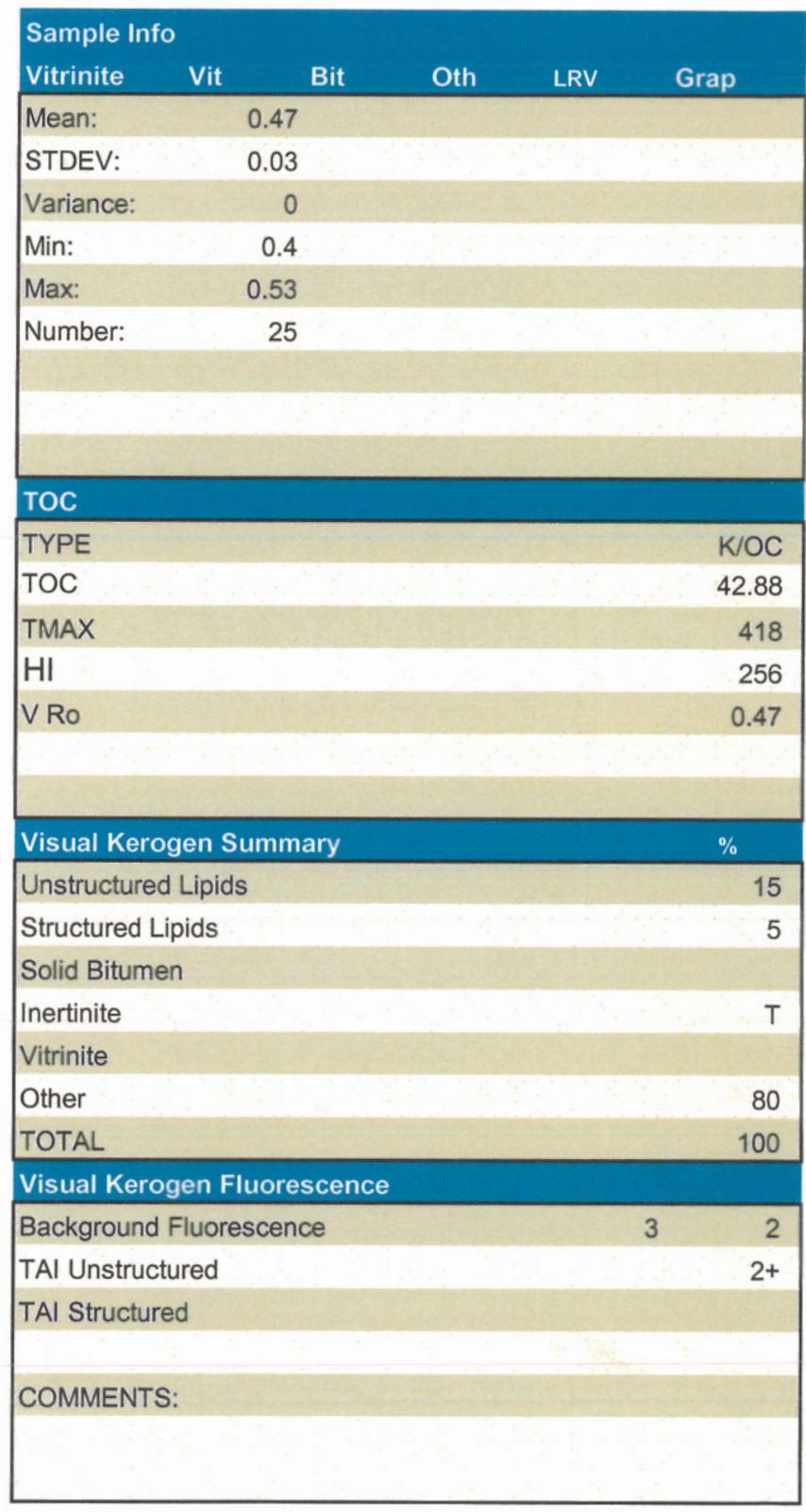




\section{BASELINE DGSIVITRINITE REFLECTANCE}

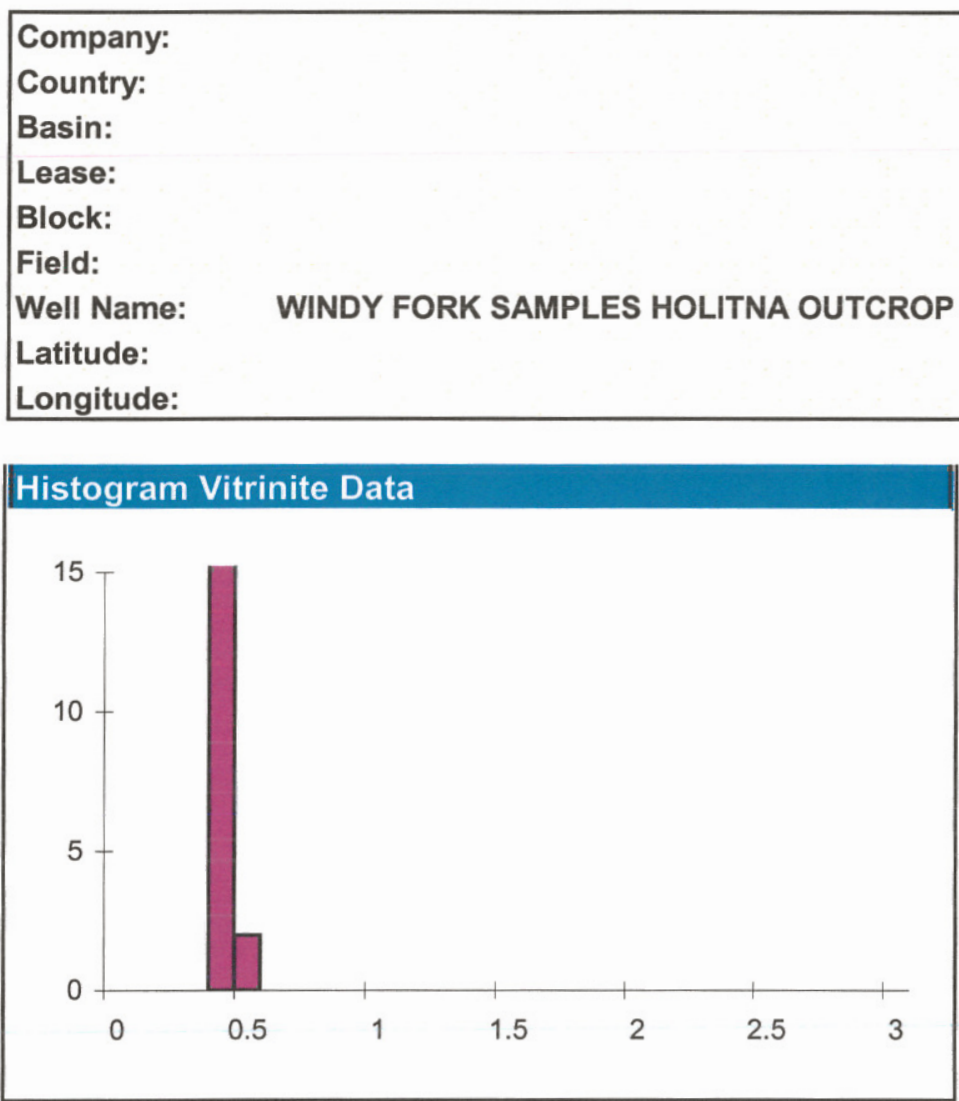

\begin{tabular}{||ll||}
\hline Vitrinite Data: \\
\hline $\mathrm{L} 0.401$ & $\mathrm{~L} 0.47$ \\
$\mathrm{~L} 0.41$ & $\mathrm{~L} 0.47$ \\
$\mathrm{~L} 0.42$ & $\mathrm{~L} 0.48$ \\
$\mathrm{~L} 0.43$ & $\mathrm{~L} 0.48$ \\
$\mathrm{~L} 0.44$ & $\mathrm{~L} 0.48$ \\
$\mathrm{~L} 0.44$ & $\mathrm{~L} 0.49$ \\
$\mathrm{~L} 0.44$ & $\mathrm{~L} 0.501$ \\
$\mathrm{~L} 0.44$ & $\mathrm{~L} 0.54$ \\
$\mathrm{~L} 0.45$ & \\
$\mathrm{~L} 0.45$ & \\
$\mathrm{~L} 0.45$ & \\
$\mathrm{~L} 0.45$ & \\
$\mathrm{~L} 0.45$ & \\
$\mathrm{~L} 0.45$ & \\
$\mathrm{~L} 0.46$ & \\
$\mathrm{~L} 0.46$ & \\
$\mathrm{~L} 0.46$ & \\
$\mathrm{~L} 0.46$ & \\
$\mathrm{~L} 0.46$ & \\
\hline
\end{tabular}

Client ID:

Project \#:

Lab ID:

Sample Type:

Sampling Point:

Formation:

Geologic Age:

Top Depth:

Bottom Depth:

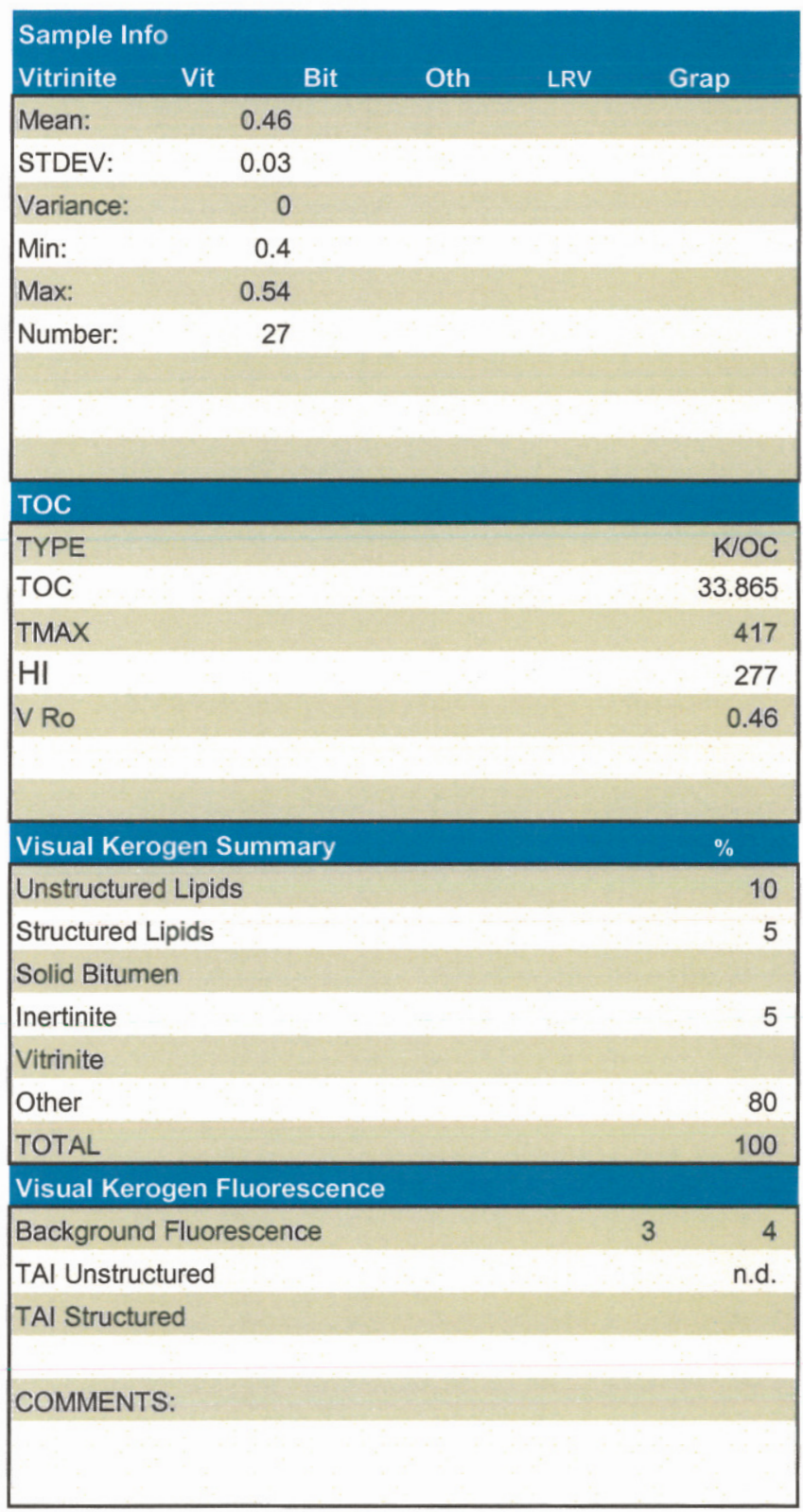

02DL53 80 WF

03-211-A

WD000178

ОTCP
Baseline/DGSI - USA

The Woodlands, TX 77381-424

Telephone: $281-681-2200$

E-mail: info abaselinedosi.com

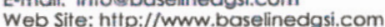




\section{h. BASELINE DGSI VITRINITE REFLECTANCE}

Company:
Country:
Basin:
Lease:
Block:
Field:
Well Name: WINDY FORK SAMPLES HOLITNA OUTCROP
Latitude:
Longitude:

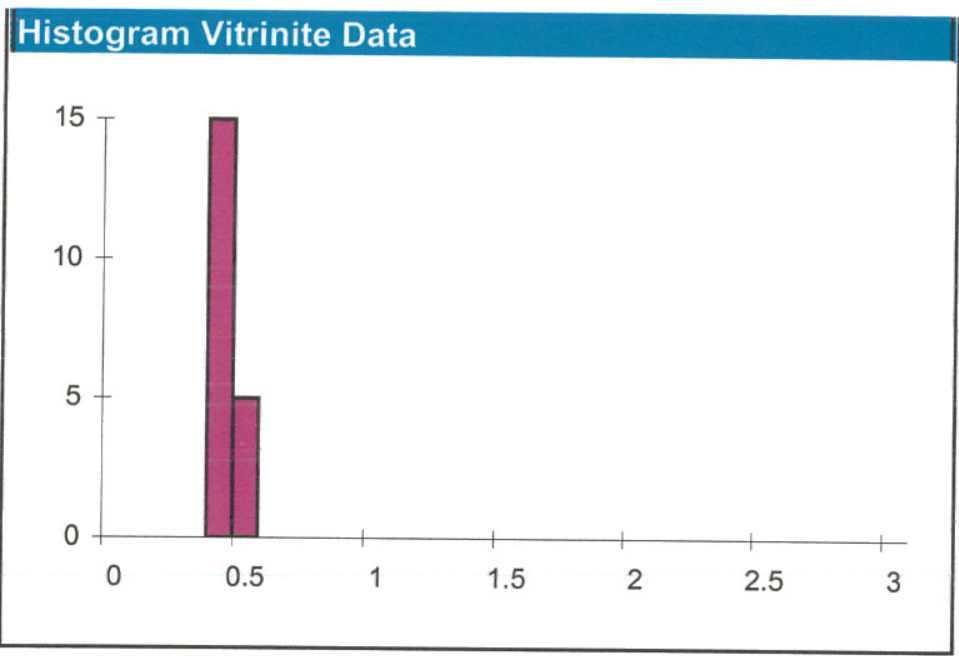

\begin{tabular}{||ll||}
\hline Vitrinite Data: \\
\hline $\mathrm{L} 0.42$ & L0.52 \\
$\mathrm{L} 0.42$ & \\
$\mathrm{~L} 0.43$ & \\
$\mathrm{~L} 0.43$ & \\
$\mathrm{~L} 0.43$ & \\
$\mathrm{~L} 0.46$ \\
$\mathrm{~L} 0.46$ \\
$\mathrm{~L} 0.47$ \\
$\mathrm{~L} 0.47$ \\
$\mathrm{~L} 0.47$ \\
$\mathrm{~L} 0.48$ \\
$\mathrm{~L} 0.48$ \\
$\mathrm{~L} 0.48$ \\
$\mathrm{~L} 0.49$ \\
$\mathrm{~L} 0.49$ \\
$\mathrm{~L} 0.501$ \\
$\mathrm{~L} 0.501$ \\
$\mathrm{~L} 0.51$ \\
$\mathrm{~L} 0.51$ \\
\hline
\end{tabular}

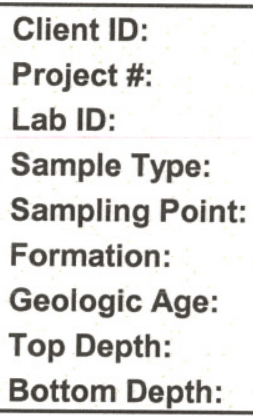

Client ID:

Project \#:

Lab ID:

Sample Type:

Sampling Point:

Formation:

Geologic Age:

Top Depth:

Bottom Depth:

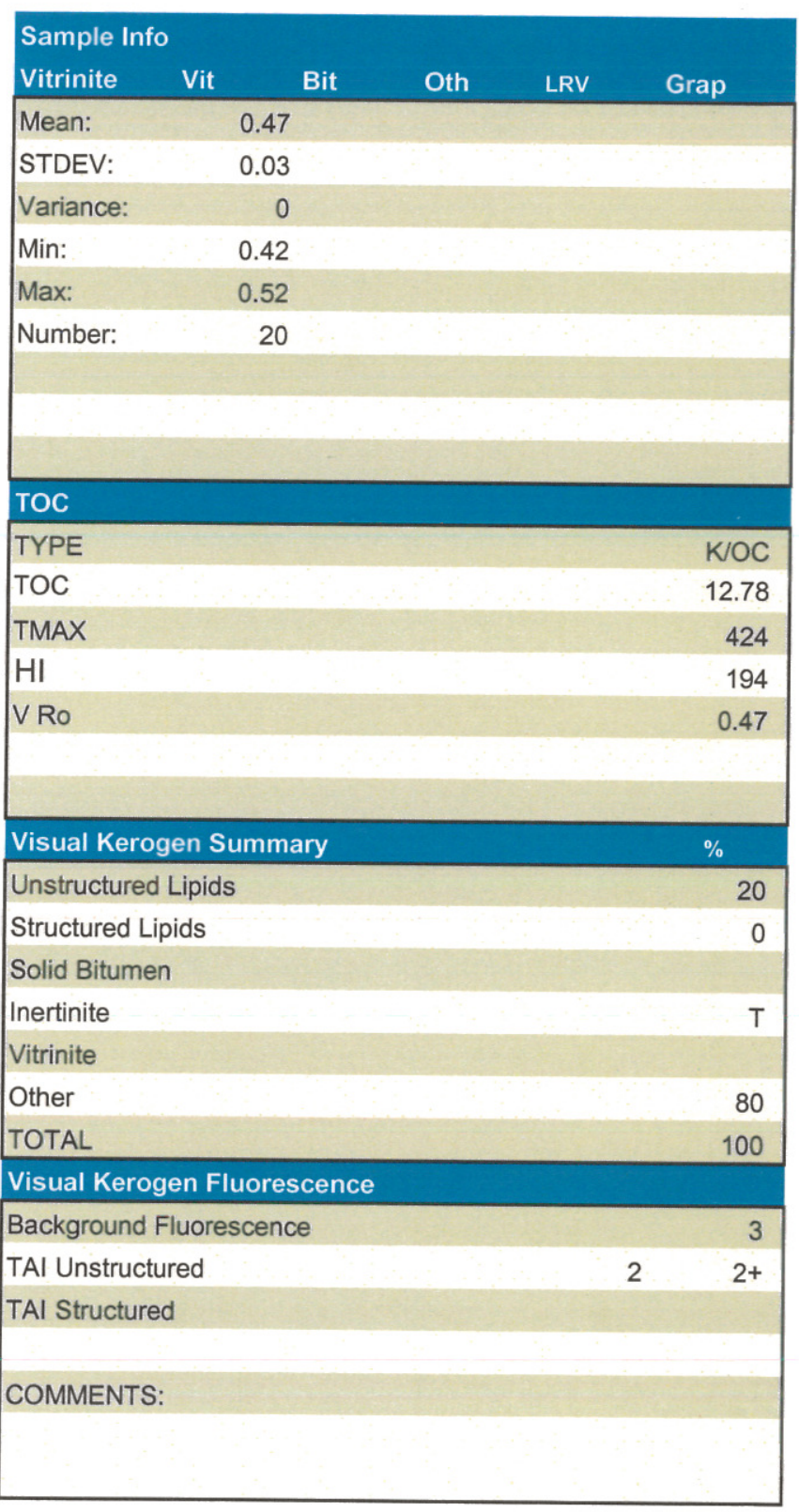




\section{BASELINE DESI VITRINITE REFLECTANCE}

\begin{tabular}{llll}
\hline Company: & Client ID: & 02DL54 A WF \\
Country: & Project \#: & 03-211-A \\
Basin: & Lab ID: & WD000183 \\
Lease: & Sample Type: & OTCP \\
Block: & Sampling Point: & \\
Field: & Formation: \\
Well Name: & WINDY FORK SAMPLES HOLITNA OUTCROP & \\
Latitude: & & Geologic Age: \\
Longitude: & Top Depth: & \\
& Bottom Depth: \\
\hline
\end{tabular}

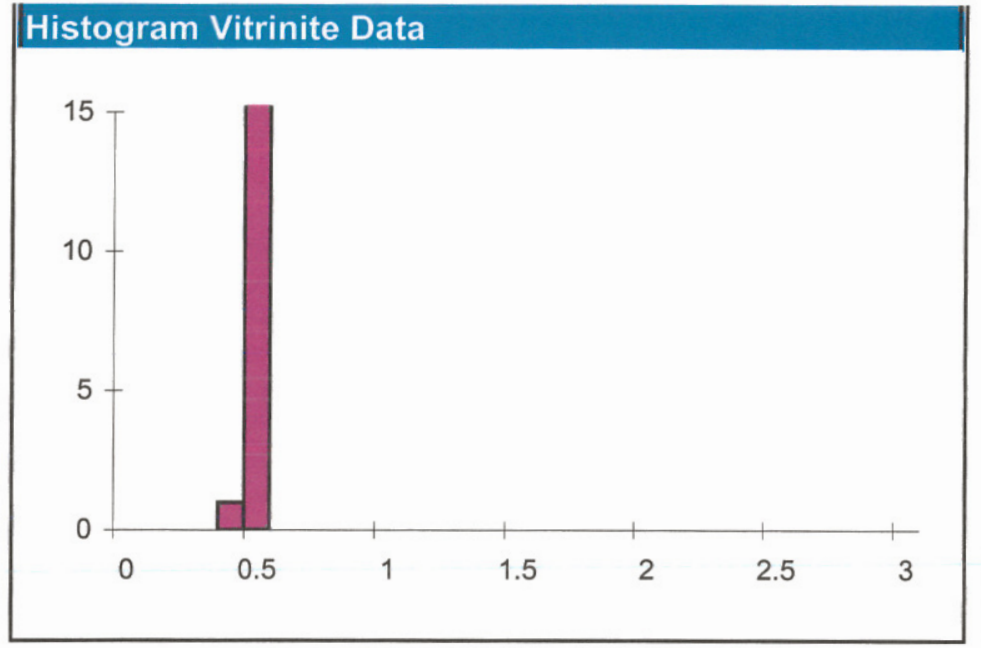

\begin{tabular}{||ll|||}
\hline Vitrinite Data: \\
\hline $\mathrm{L} 0.47$ & L0.55 \\
$\mathrm{L} 0.501$ & $\mathrm{~L} 0.55$ \\
$\mathrm{~L} 0.51$ & $\mathrm{~L} 0.57$ \\
$\mathrm{~L} 0.51$ & $\mathrm{~L} 0.57$ \\
$\mathrm{~L} 0.51$ & \\
$\mathrm{~L} 0.51$ & \\
$\mathrm{~L} 0.51$ & \\
$\mathrm{~L} 0.52$ & \\
$\mathrm{~L} 0.52$ & \\
$\mathrm{~L} 0.52$ & \\
$\mathrm{~L} 0.53$ & \\
$\mathrm{~L} 0.53$ & \\
$\mathrm{~L} 0.53$ & \\
$\mathrm{~L} 0.53$ & \\
$\mathrm{~L} 0.54$ & \\
$\mathrm{~L} 0.54$ & \\
$\mathrm{~L} 0.54$ & \\
$\mathrm{~L} 0.54$ & \\
$\mathrm{~L} 0.55$ & \\
\hline
\end{tabular}

\begin{tabular}{|c|c|c|c|c|c|}
\hline \multicolumn{6}{|c|}{ Sample Info } \\
\hline \multirow{2}{*}{\multicolumn{6}{|c|}{\begin{tabular}{|l} 
Vitrinite \\
Mean:
\end{tabular}}} \\
\hline & & & & & \\
\hline STDEV: & \multicolumn{5}{|c|}{0.02} \\
\hline Variance: & \multicolumn{5}{|c|}{0} \\
\hline Min: & \multicolumn{5}{|c|}{0.47} \\
\hline Max: & \multicolumn{5}{|c|}{0.57} \\
\hline Number: & \multicolumn{5}{|c|}{23} \\
\hline \multicolumn{6}{|l|}{ TOC } \\
\hline \multicolumn{4}{|l|}{ TYPE } & \multicolumn{2}{|r|}{$\mathrm{K} / \mathrm{OC}$} \\
\hline \multicolumn{4}{|l|}{ TOC } & \multicolumn{2}{|r|}{4.84} \\
\hline \multicolumn{4}{|l|}{ TMAX } & \multicolumn{2}{|r|}{429} \\
\hline \multicolumn{4}{|l|}{$\mathrm{HI}$} & \multicolumn{2}{|r|}{15} \\
\hline \multicolumn{4}{|l|}{ V Ro } & \multicolumn{2}{|r|}{0.53} \\
\hline \multicolumn{5}{|c|}{ Visual Kerogen Summary } & $\%$ \\
\hline \multicolumn{4}{|c|}{ Unstructured Lipids } & & 30 \\
\hline \multicolumn{4}{|c|}{ Structured Lipids } & & 5 \\
\hline \multicolumn{6}{|c|}{ Solid Bitumen } \\
\hline \multicolumn{4}{|l|}{ Inertinite } & & $\mathrm{T}$ \\
\hline \multicolumn{6}{|l|}{ Vitrinite } \\
\hline \multicolumn{4}{|l|}{ Other } & & 65 \\
\hline \multicolumn{4}{|l|}{ TOTAL } & & 100 \\
\hline \multicolumn{6}{|c|}{ Visual Kerogen Fluorescence } \\
\hline Backgrou & Fluores & & & & 3 \\
\hline TAI Unstr & ured & & & & $2+$ \\
\hline TAI Struct & & & & & \\
\hline COMMEN & & & & & \\
\hline
\end{tabular}

Baseline DGSI - Brazil

Rua Benjamin Balista 55 / 301 Jardim Bołânico.

22461-120 Rio de Janeiro (RJ) - Brazil

Telifax: + $55.21 / 5377893$

E-mail: ssp@solintec.com.br 
VITRINITE REFLECTANCE

Company:
Country:
Basin:
Lease:
Block:
Field:
Well Name: WINDY FORK SAMPLES HOLITNA OUTCROP
Latitude:
Longitude:
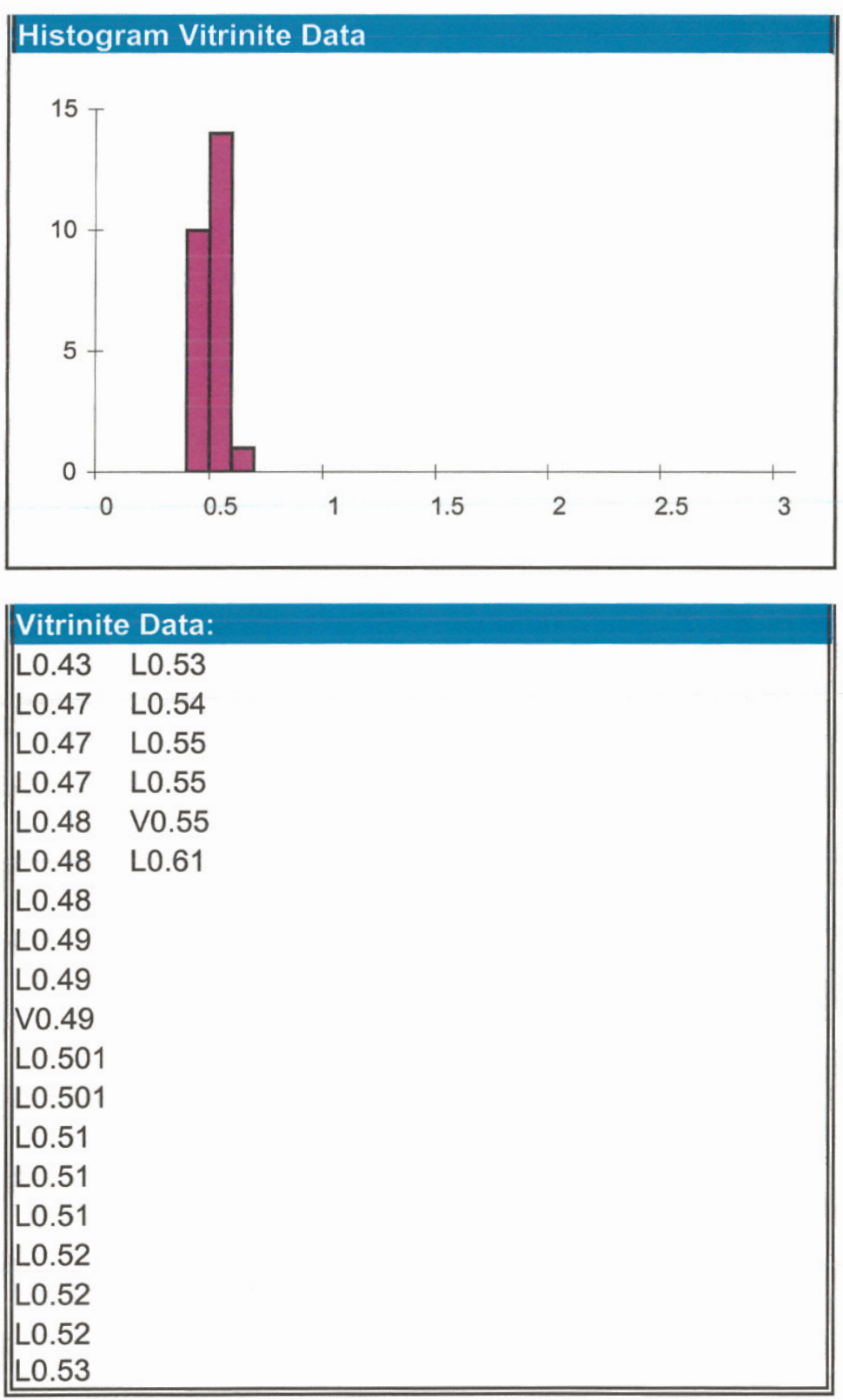

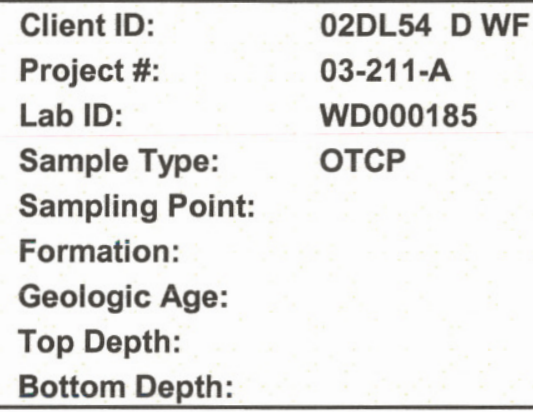

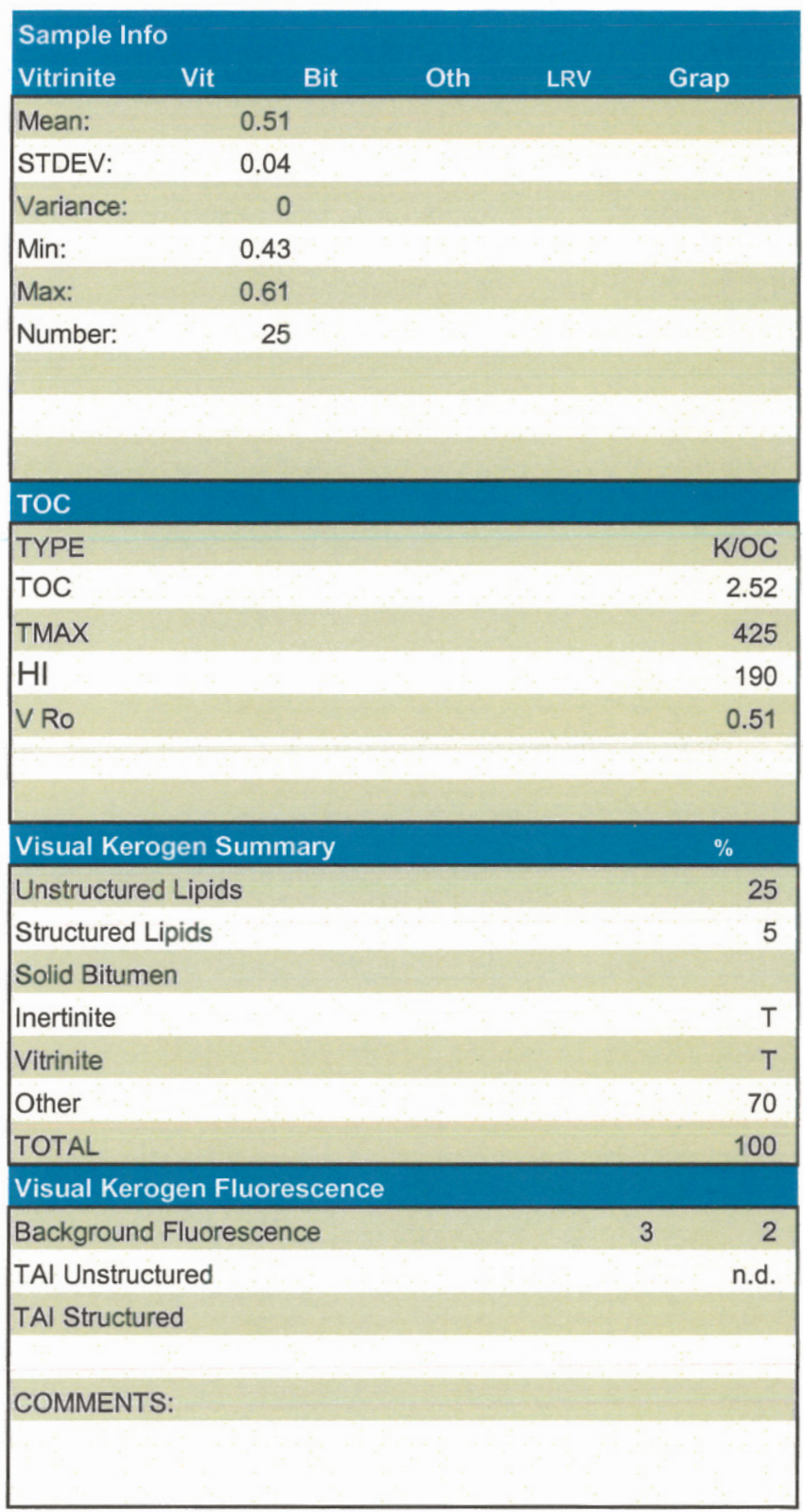




\section{BASELINE DCSI VITRINITE REFLETANCE}

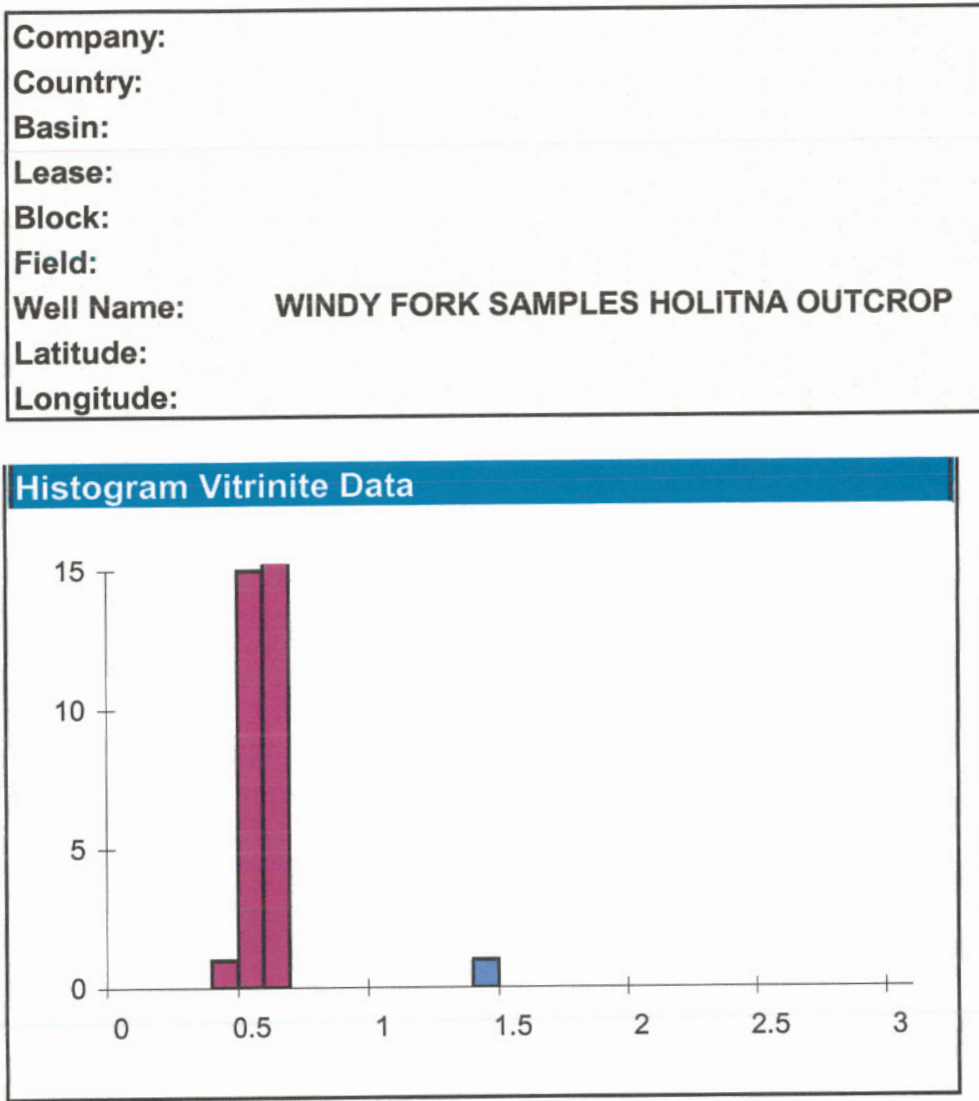

\section{Vitrinite Data:}

\begin{tabular}{||ll} 
V0.49 & V0.62 \\
$\mathrm{L} 0.501$ & $\mathrm{~V} 0.62$ \\
$\mathrm{~V} 0.52$ & $\mathrm{~V} 0.62$ \\
$\mathrm{~L} 0.53$ & $\mathrm{~V} 0.63$ \\
$\mathrm{~L} 0.54$ & $\mathrm{~V} 0.63$ \\
$\mathrm{~L} 0.54$ & $\mathrm{~V} 0.63$ \\
$\mathrm{~V} 0.54$ & $\mathrm{~V} 0.63$ \\
$\mathrm{~V} 0.54$ & $\mathrm{~V} 0.63$ \\
$\mathrm{~V} 0.55$ & $\mathrm{~V} 0.64$ \\
$\mathrm{~L} 0.56$ & $\mathrm{~V} 0.64$ \\
$\mathrm{~L} 0.56$ & $\mathrm{~V} 0.65$ \\
$\mathrm{~L} 0.57$ & $\mathrm{~V} 0.65$ \\
$\mathrm{~L} 0.57$ & $\mathrm{~V} 0.65$ \\
$\mathrm{~V} 0.57$ & $\mathrm{~V} 0.66$ \\
$\mathrm{~V} 0.57$ & $\mathrm{~V} 0.67$ \\
$\mathrm{~L} 0.59$ & $\mathrm{~V} 1.48$ \\
$\mathrm{~V} 0.601$ & \\
$\mathrm{~V} 0.62$ & \\
$\mathrm{~V} 0.62$ & \\
\hline
\end{tabular}

Client ID:

Project \#:

Lab ID:

Sample Type:

Sampling Point:

Formation:

Geologic Age:

Top Depth:

Bottom Depth:

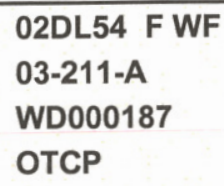

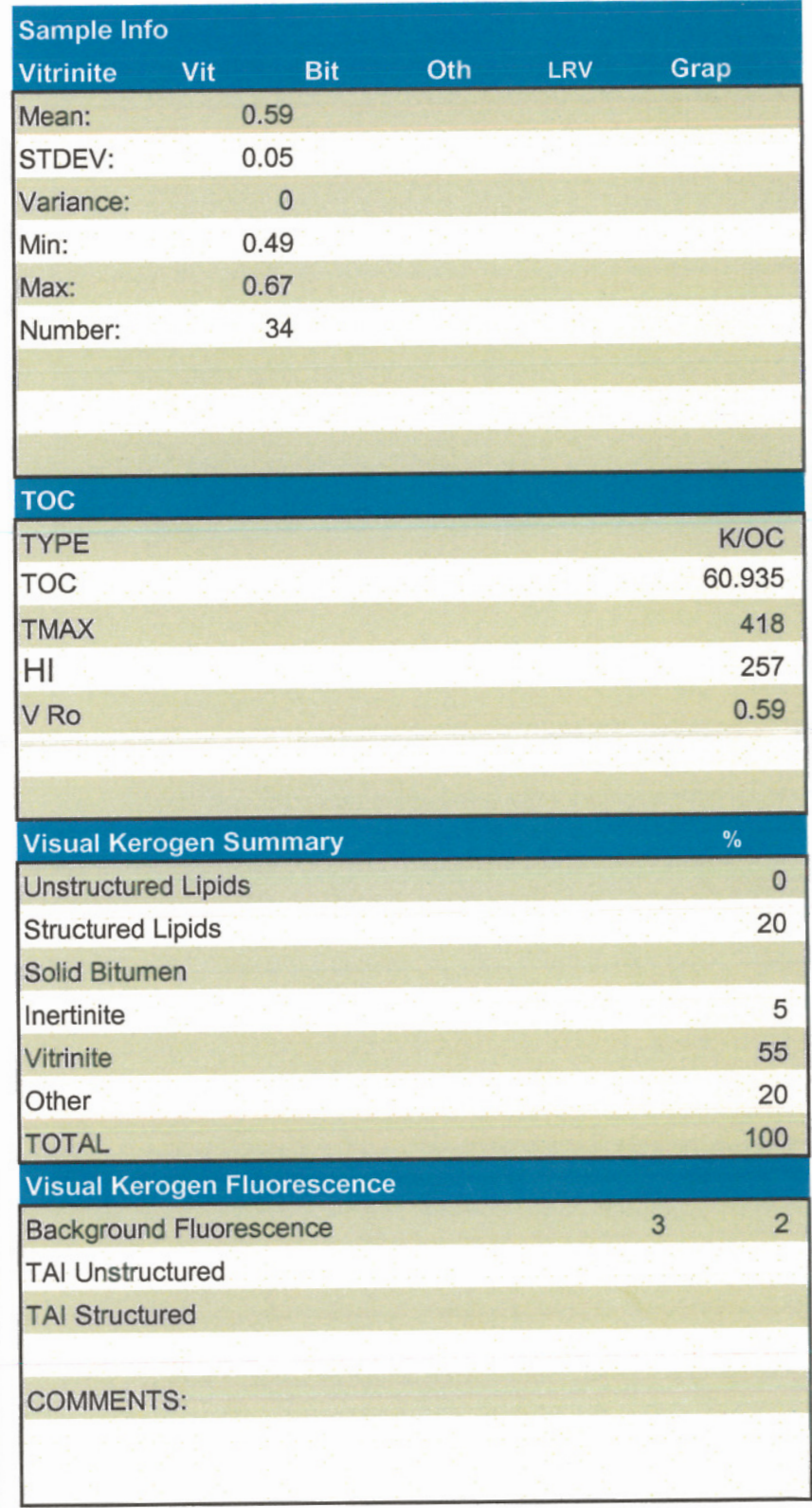

Baselline/DGSI - USA

8701 New Trails Drive. The Woodlands, TX 77381-424

Telephone: $281-681-2200$

Facsimile: $281-681.0326$

E-mail: info@boselinedgsi.com

Web Site: http://uww.baselinedgsi.com
Baseline DGS1 - Brazil

Rua Benjamin Batista 55 / 301 Jardim Botânico.

2246i-120 Rio de Janeiro (RJ) - Brazil

Tel/Fax: + $55.21 / 5377893$

E-mail: ssp@solintec.com. 


\section{GAS CHROMATOGRAPHY High Resolution Capillary GC (HRCGC)}

\section{Techniques and Parameters}

High Resolution Capillary Gas Chromatography (HRCGC) is an analytical technique which is used to separate and identify a multitude of hydrocarbon compounds in a crude oil or a rock extract. A single analysis on an oil can resolve compounds in great detail between $\mathrm{C}_{2}$ and $\mathrm{C}_{40}$ which previously took three separate runs to achieve. For a rock extract only the fraction $\mathrm{C}_{15+}$ is preserved. Compounds less than $\mathrm{C}_{15}$ are partially lost during extraction. Key compounds are identified and ratios calculated which are then used to interpret the kerogen type, organic facies, depositional environment and thermal history in the source rocks; the origin, type, thermal maturity and other alteration effects including water washing, biodegradation and evaporative fractionation in crude oils; and to help make oil-oil and oil-source rock correlations.

\section{Whole Extract Gas Chromatography}

About 50 grams of sample are crushed, passed through a 20 micron sieve, accurately weighed, and soxhlet extracted for 16 hours with dichloromethane. Other solvents can be substituted if desired. The solvent is evaporated and the residue weighed to obtain the weight percent of total organic extract. The advantage to doing whole extract chromatography is that more of the lighter fraction $\left(\mathrm{C}_{10}-\mathrm{C}_{15}\right)$ is preserved than if the saturated fraction were separated by column chromatography. A disadvantage is that nonsaturate compounds are retained which may complicate the chromatogram. Fortunately, this is a problem only in some relatively immature extracts. A sample of whole extract is injected directly into a gas chromatograph fitted with the same GC column and using the same temperature programming and computer software described in the section on whole oil analysis. A gas chromatogram as shown in Figure 1A is provided.

Whole extract gas chromatography provides information on the organic facies and thermal maturity of source rocks, on migrated petroleum, and serves as a basis for oil-rock correlations. It is recommended primarily to evaluate known or suspected source beds, oil shows, samples with anomalous pyrolysis $S_{1}$ values and to identify possible contamination products.

\section{Aromatic GC}

High Pressure Liquid Chromatography is used to prepare an aromatic fraction, which is then injected into a Varian model 3400 gas chromatograph, fitted with a Quadrex 50 meter fused silica capillary column. The GC is programmed from $40^{\circ} \mathrm{C}$ to $350^{\circ} \mathrm{C}$ at $10^{\circ} \mathrm{C} /$ minute with a two minute hold at $40^{\circ} \mathrm{C}$ and a 20 minute hold at $350^{\circ} \mathrm{C}$. Analytical data are processed with Genie Software System ${ }^{\circledR}$ and HP ChemStation data acquisition software. This software system facilitates data processing and graphic display as well as electronic data transmission. Thirty-three aromatic hydrocarbons are separated and detected and these are broken down into six aromatic hydrocarbon types.

\section{Whole Oil GC}

A sample of whole oil is injected directly into a Varian model 3400 gas chromatograph fitted with a Quadrex 50 meter fused silica capillary column. The GC is programmed from 40 to $350^{\circ} \mathrm{C}$ at $10^{\circ} \mathrm{C} /$ minute with a 2 minute hold at $40^{\circ}$ and a 20 minute hold at $350^{\circ} \mathrm{C}$. Analytical data are processed with Genie Software System and HP ChemStation data acquisition software. This software system facilitates data processing and graphic display as well as electronic data transmittal. All standard calculations are made including pristane/phytane ratio, carbon preference index, and other key parameters (Tables 1 and 2). Two gas chromatograms are provided, one showing all compounds between $\mathrm{nC}_{2}$ and $\mathrm{nC}_{40}$ (Figure $1 \mathrm{~A}$ ) and the other a computer enhanced version of the chromatogram between $\mathrm{nC}_{2}$ and $\mathrm{nC}_{10}$ (Figure $1 \mathrm{~B}$ ). Compounds as low as ethane can be detected if present. In addition, the concentration of $\mathrm{C}_{13}$ to $\mathrm{C}_{20}$ isoprenoids are determined and plotted (see example of standard report). 
BASELINE DCSI

ANALYTICAL LABORATORIES

WINDY FORK SAMPLES HOLITNA OUTCROPS

\begin{tabular}{|c|c|c|c|c|c|}
\hline Client ID & Lab ID & $\begin{array}{c}\text { Rock } \\
\text { Weight (g) }\end{array}$ & $\begin{array}{l}\text { Net Extract } \\
\text { Weight }(\mathrm{g})\end{array}$ & $\begin{array}{c}\% \\
\text { Extract }\end{array}$ & $\begin{array}{l}\text { EOM } \\
\text { (ppm) }\end{array}$ \\
\hline 02DL53 0.5 WF & WD000146 & 53.8083 & 0.1961 & 0.36 & 3644 \\
\hline 02DL53 11.8 WF & WD000151 & 21.3310 & 0.0944 & 0.44 & 4425 \\
\hline 02DL53 38 WF & WD000160 & 36.8598 & 0.1817 & 0.49 & 4929 \\
\hline 02DL53 42 WF & WD000162 & 37.9337 & 0.1005 & 0.26 & 2649 \\
\hline 02DL53 54 WF & WD000168 & 46.6886 & 0.0968 & 0.21 & 2073 \\
\hline 02DL53 $71 \mathrm{WF}$ & WD000174 & 46.5771 & 0.0514 & 0.11 & 1104 \\
\hline 02DL53 80 WF & WD000178 & 30.7105 & 0.1614 & 0.53 & 5256 \\
\hline 02DL54 F WF & WD000187 & 42.5603 & 0.3282 & 0.77 & 7711 \\
\hline & & & & & \\
\hline & & & & & \\
\hline & & & & & \\
\hline & & & & & \\
\hline & & & & & \\
\hline & & & & & \\
\hline & & & & & \\
\hline & & & & & \\
\hline & & & & & \\
\hline & & & & & \\
\hline & & & & & \\
\hline & & & & & \\
\hline & & & & & \\
\hline & & & & & \\
\hline & & & & & \\
\hline & & & & & \\
\hline & & & & & \\
\hline & & & & & \\
\hline & & & & & \\
\hline & & & & & \\
\hline & & & & & \\
\hline & & & & & \\
\hline & & & & & \\
\hline & & & & & \\
\hline & & & & & \\
\hline & & & & & f \\
\hline & & & & & \\
\hline & & & & & \\
\hline & & & & & \\
\hline & & & & & \\
\hline & & & & & \\
\hline & & & & & \\
\hline & & & & & \\
\hline & & & & & \\
\hline & & & & & \\
\hline & & & & & \\
\hline
\end{tabular}

Baseline/DGSI - USA

8701 New Trails Drive. The Woodlands, TX 77381-4241

Telephone: $281-681-2200$

E-mail: info@baselinedgsi.com

Web Site: http://www.baselinedgsi.com
SOXHLET

\section{Project \#: 03-211-A}

Baseline DGSI - Brazll

Rua Benjamin Batista 55 / 301 Jardim Bołânico.

22461.120 Rio de Janeiro (RJ) - Brazil

rel/Fax: + $55.21 / 5377893$

E-mail: ssp@solintec.com.b 


\section{WHOLE EXTRACT GAS CHROMATOGRAPHY}

\section{Holitna Outcrop \\ WINDY FORK SAMPLES \\ BaselineDGSI Project: 03/211A}

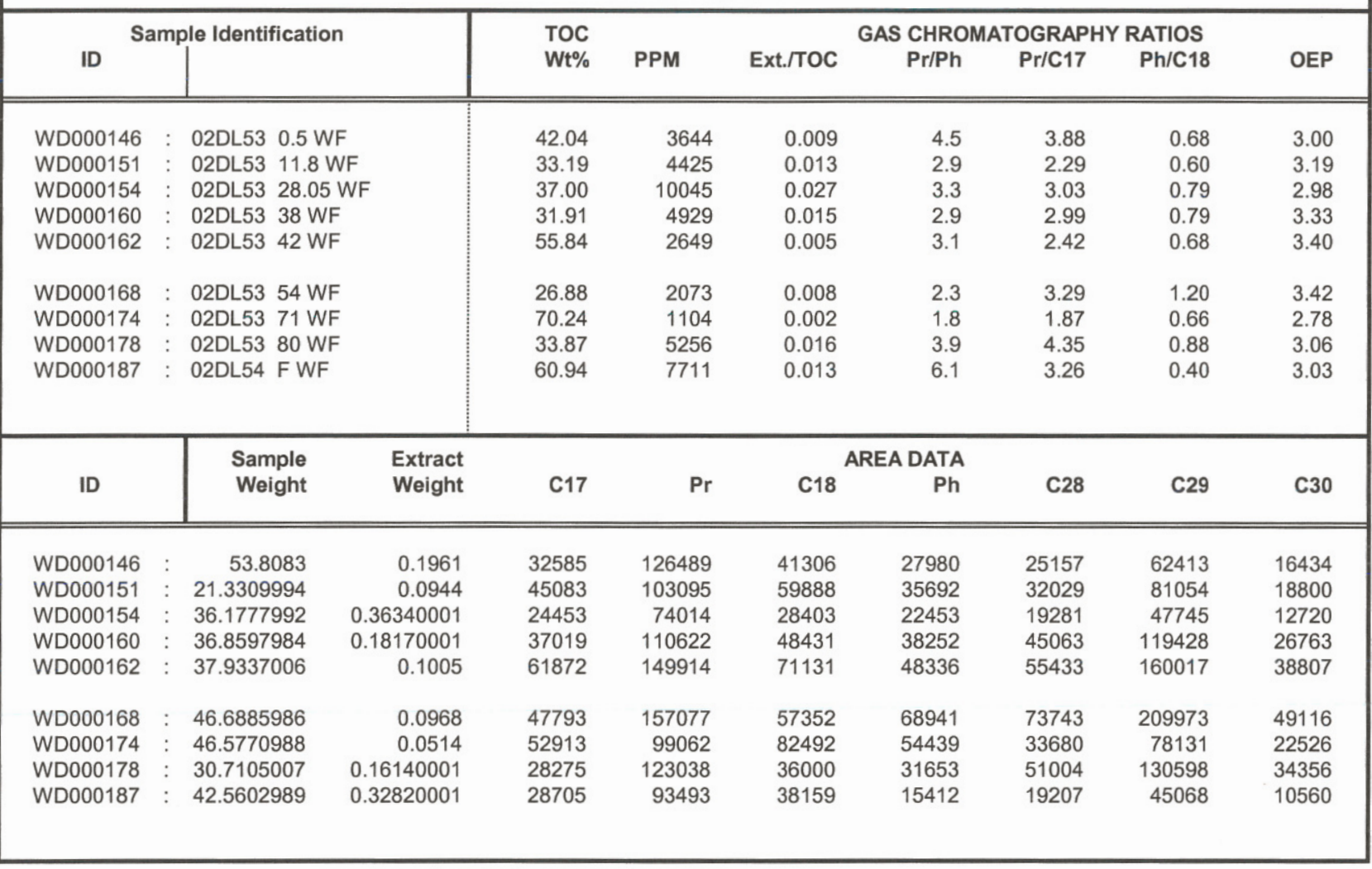




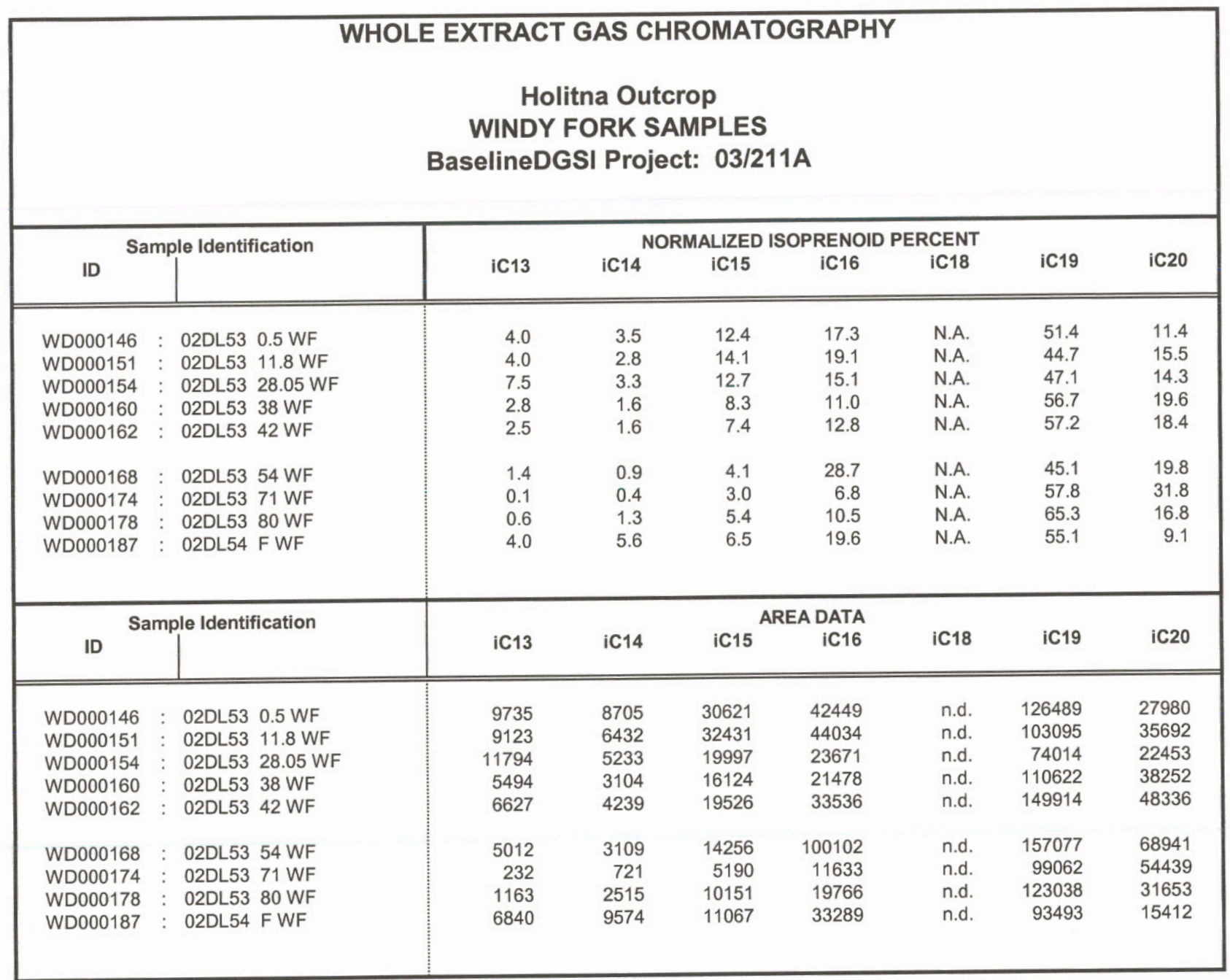




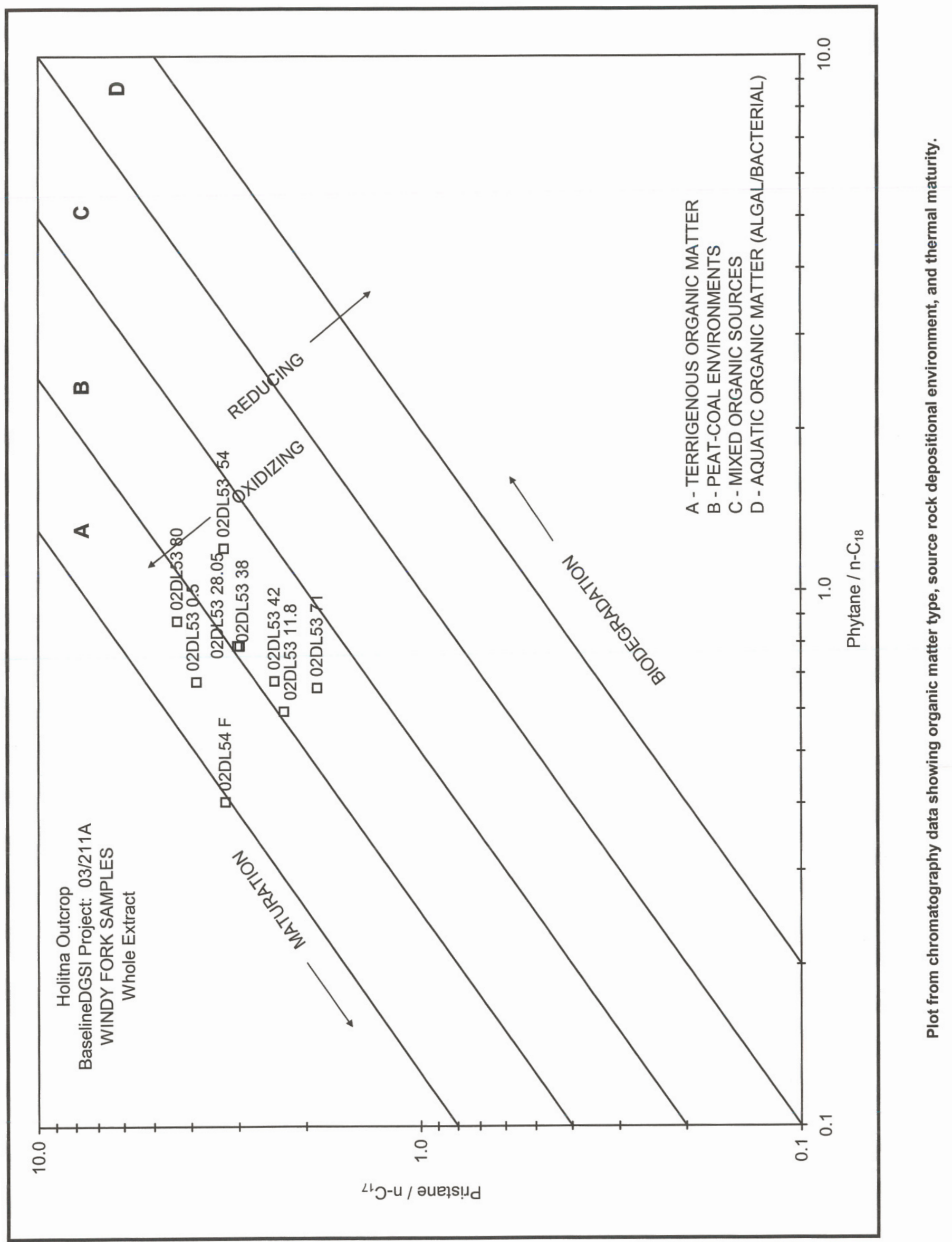




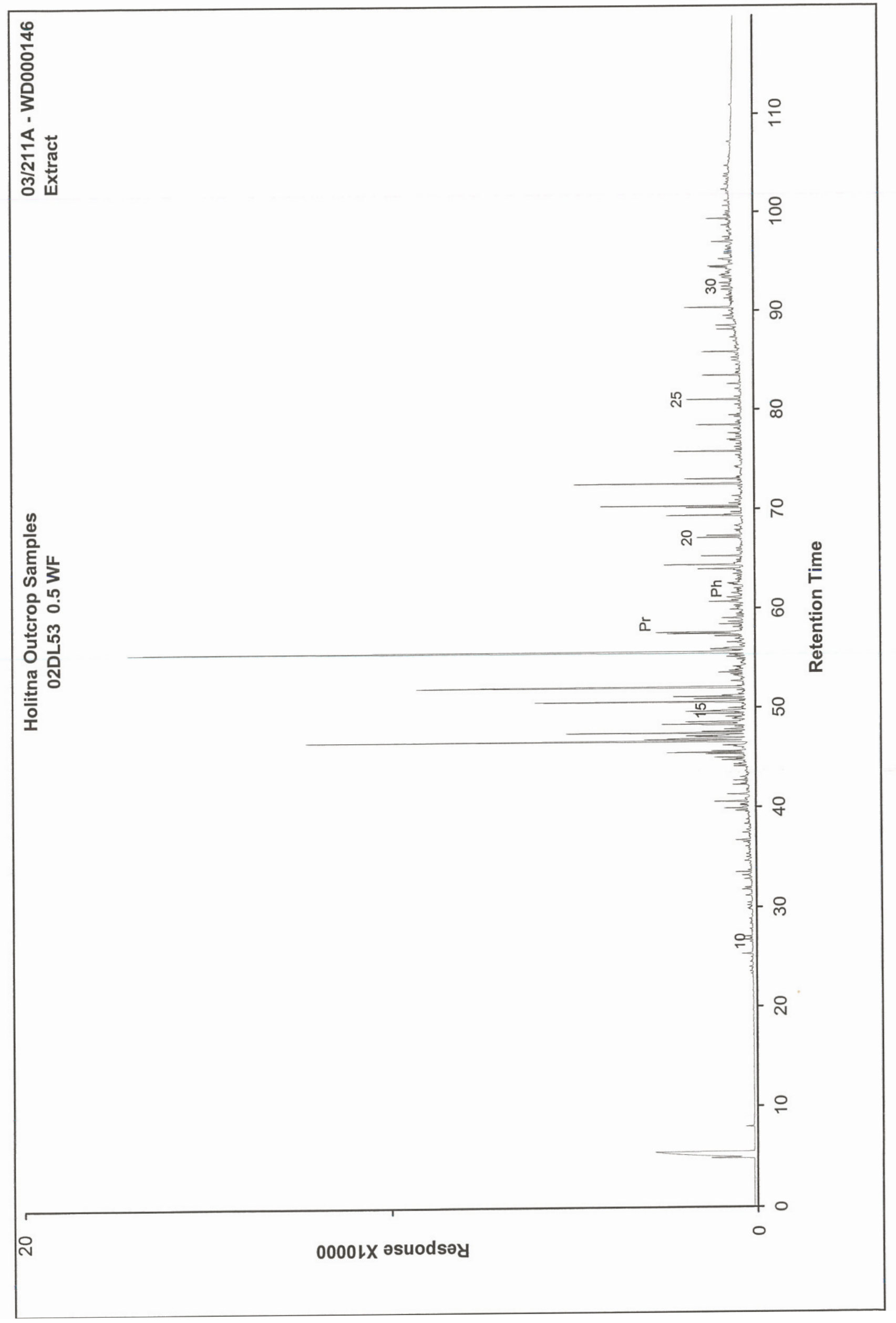




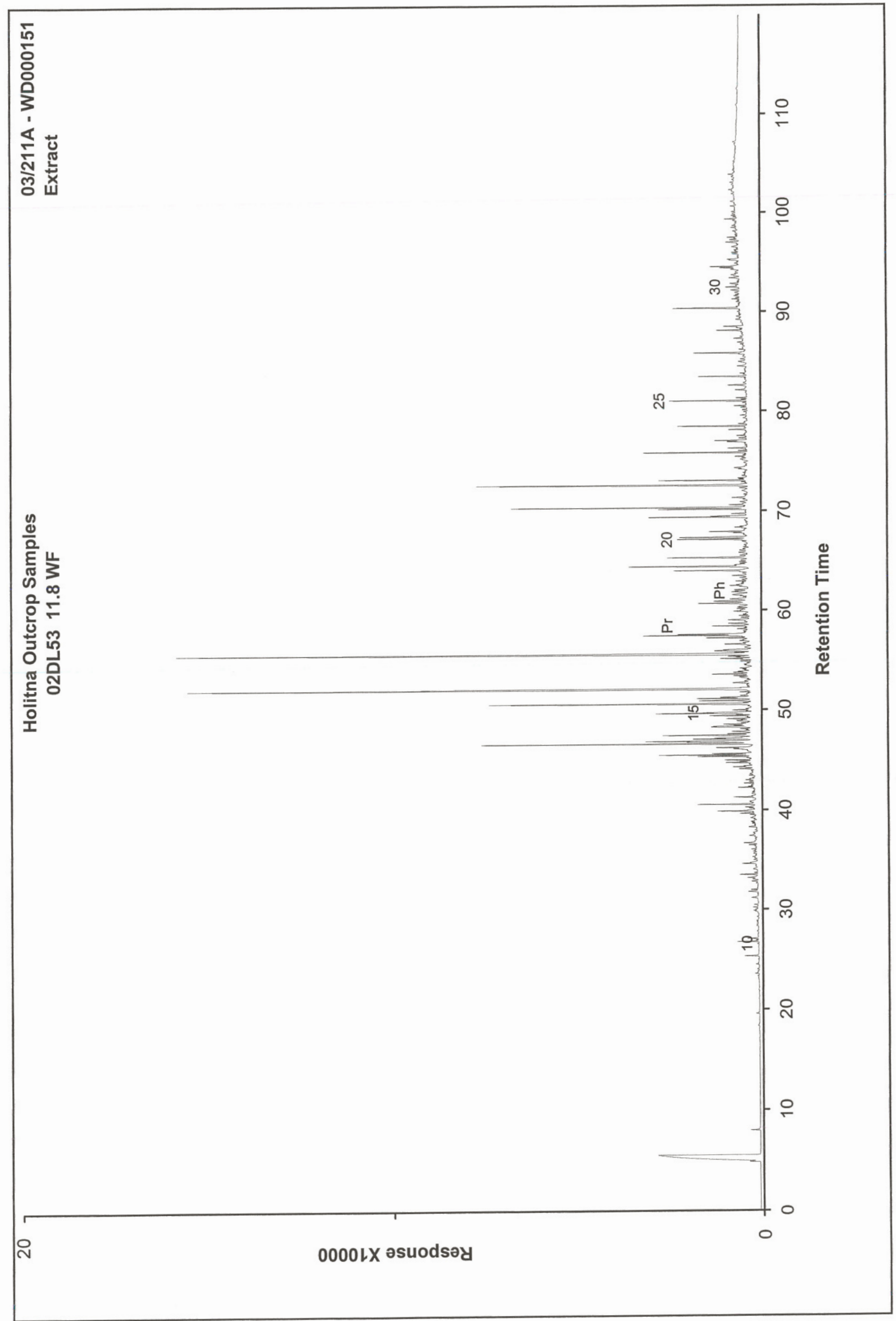




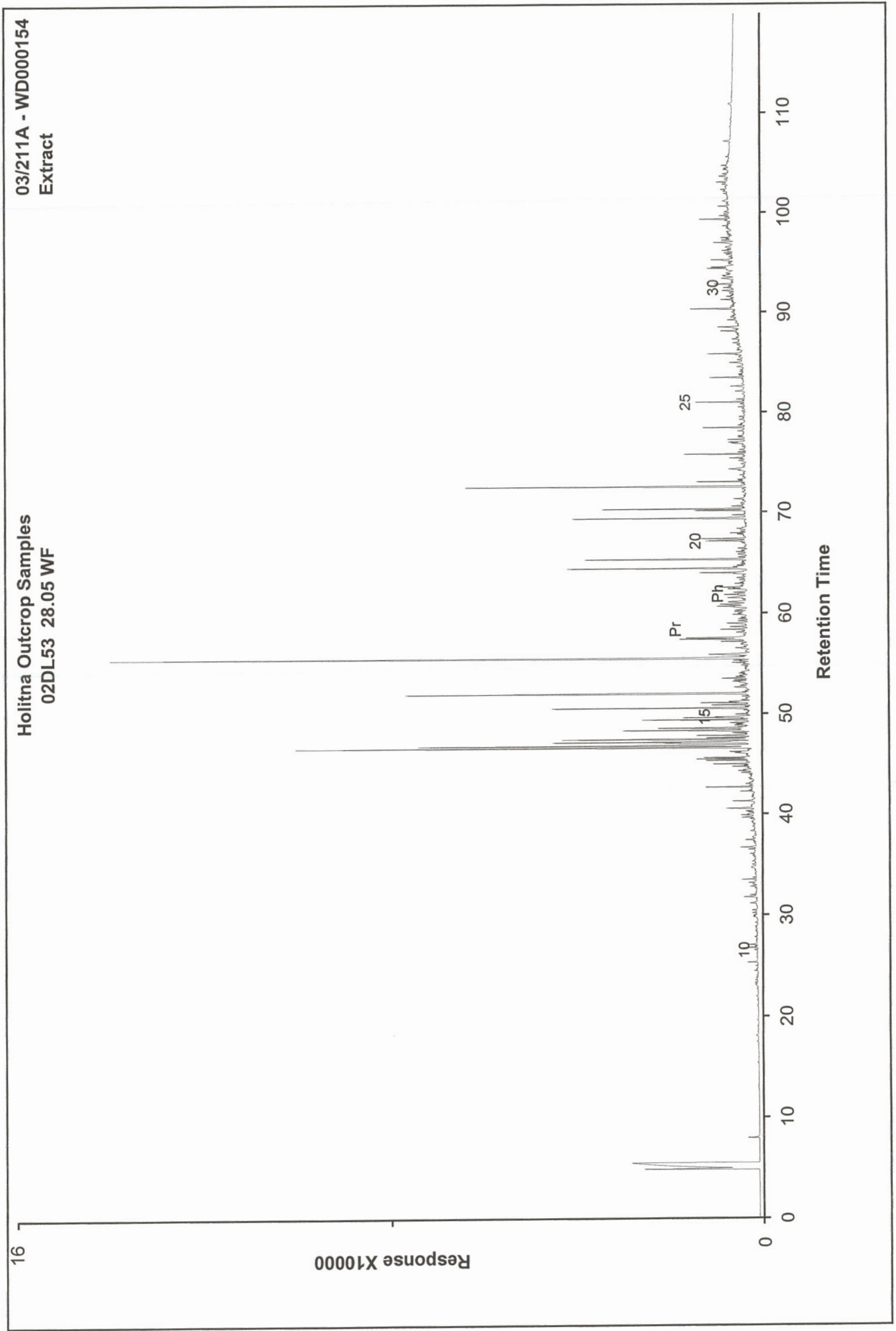




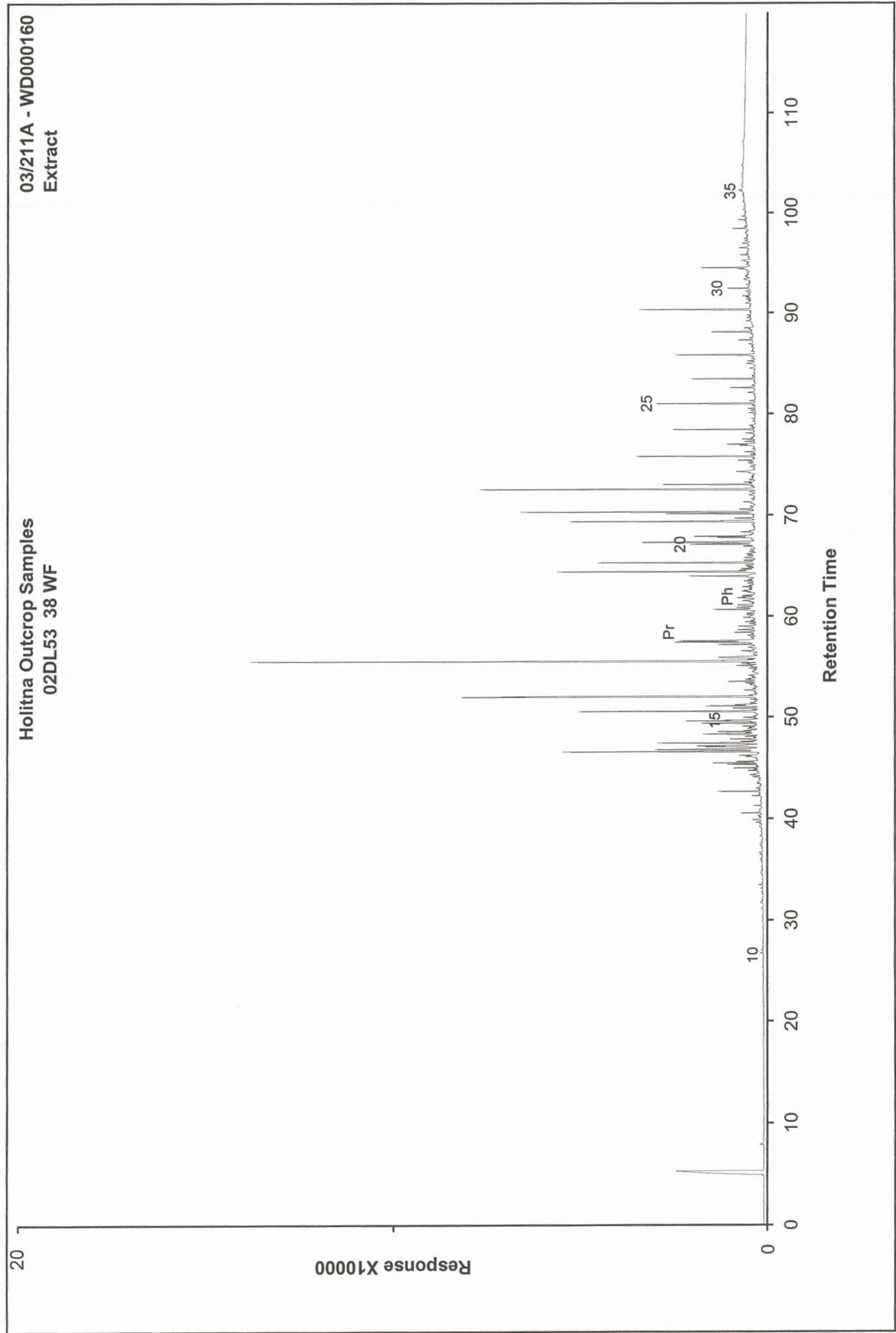




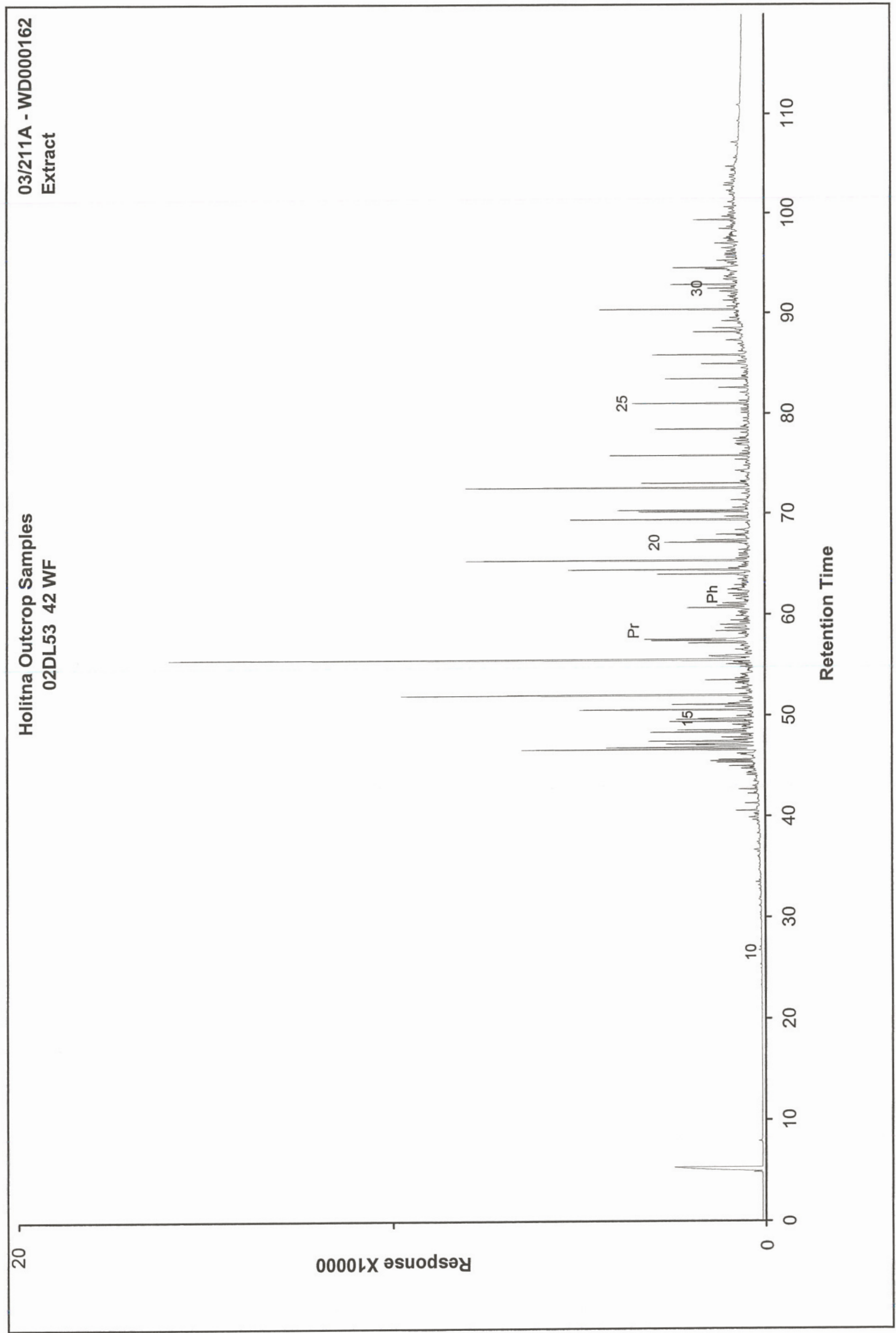




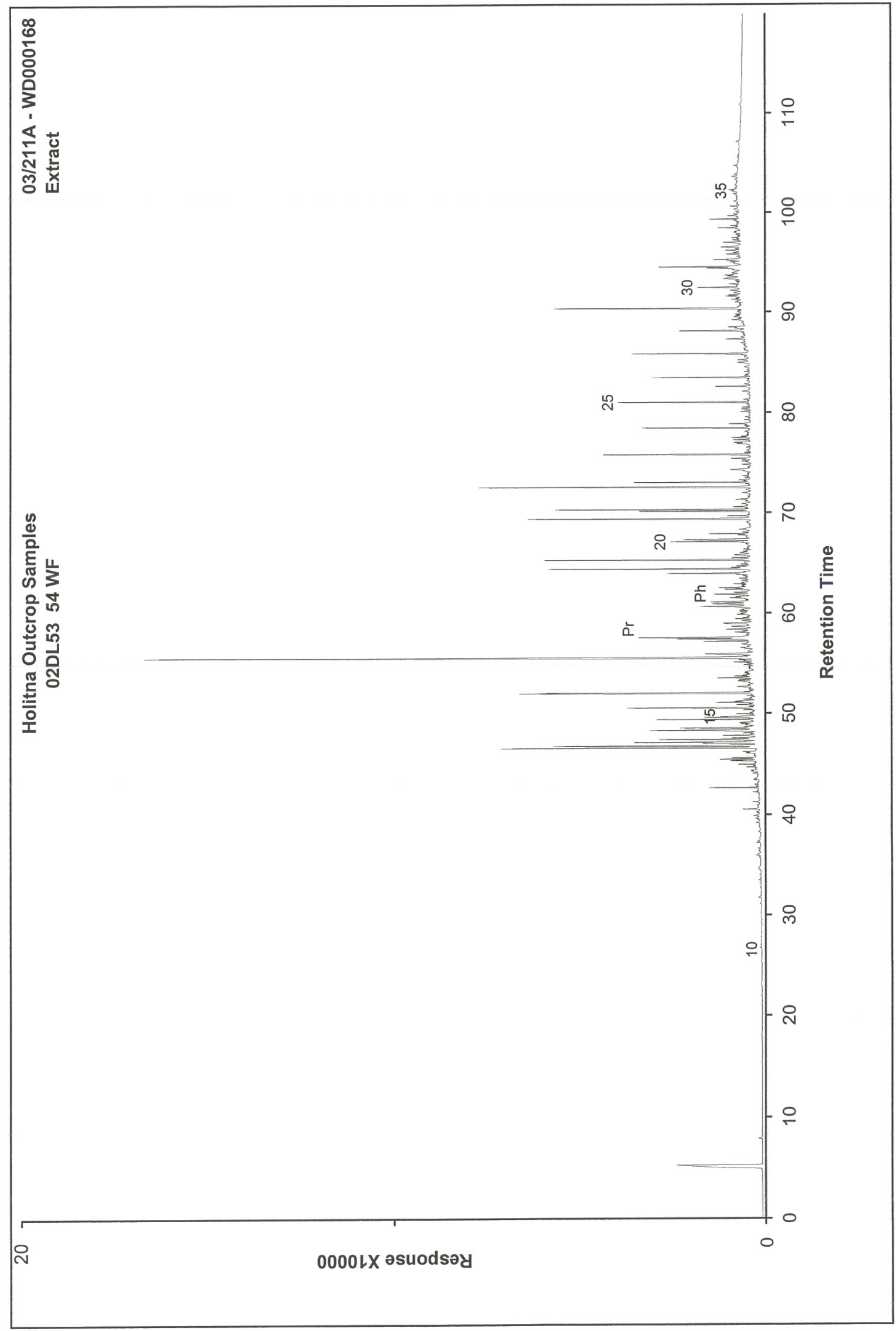




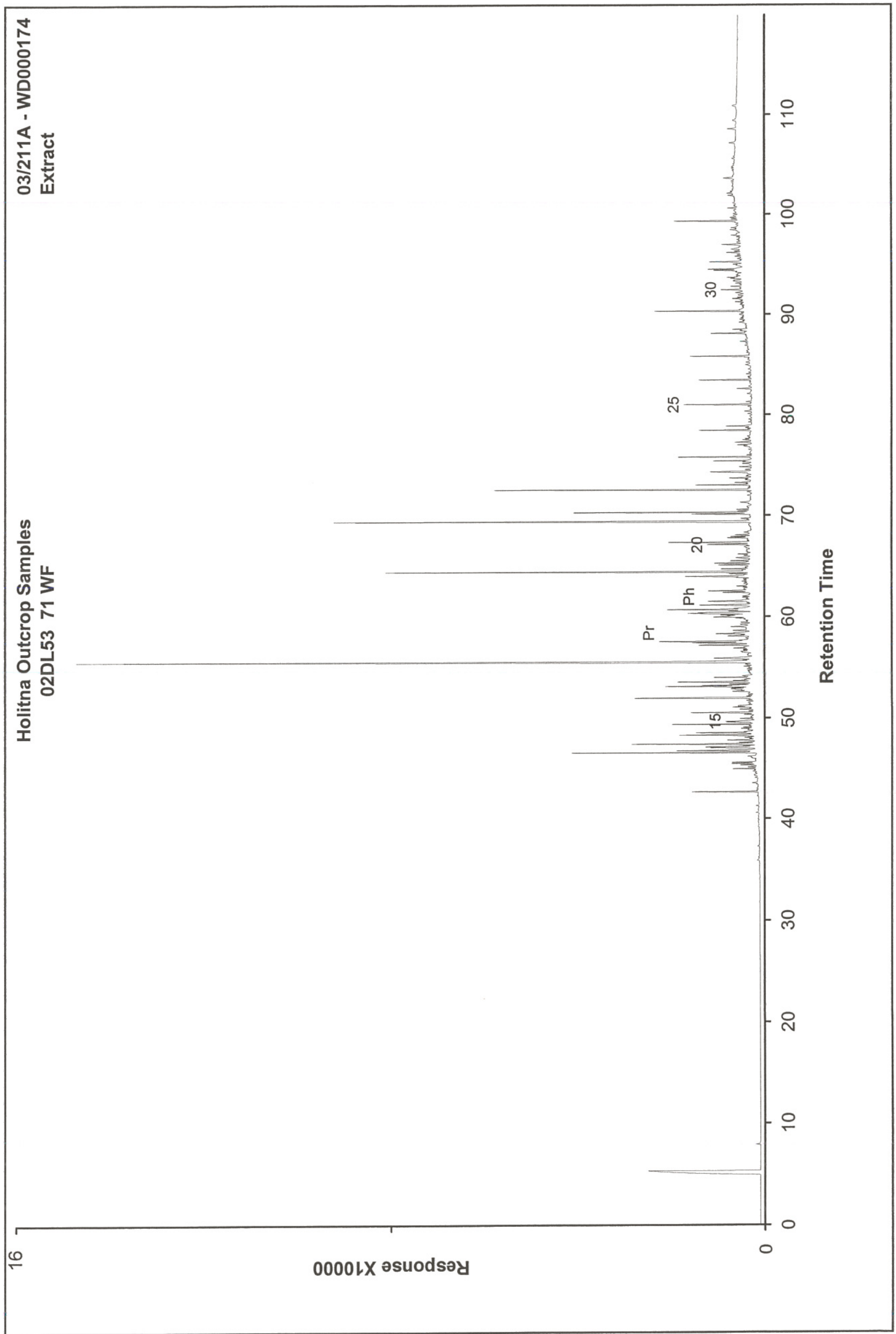




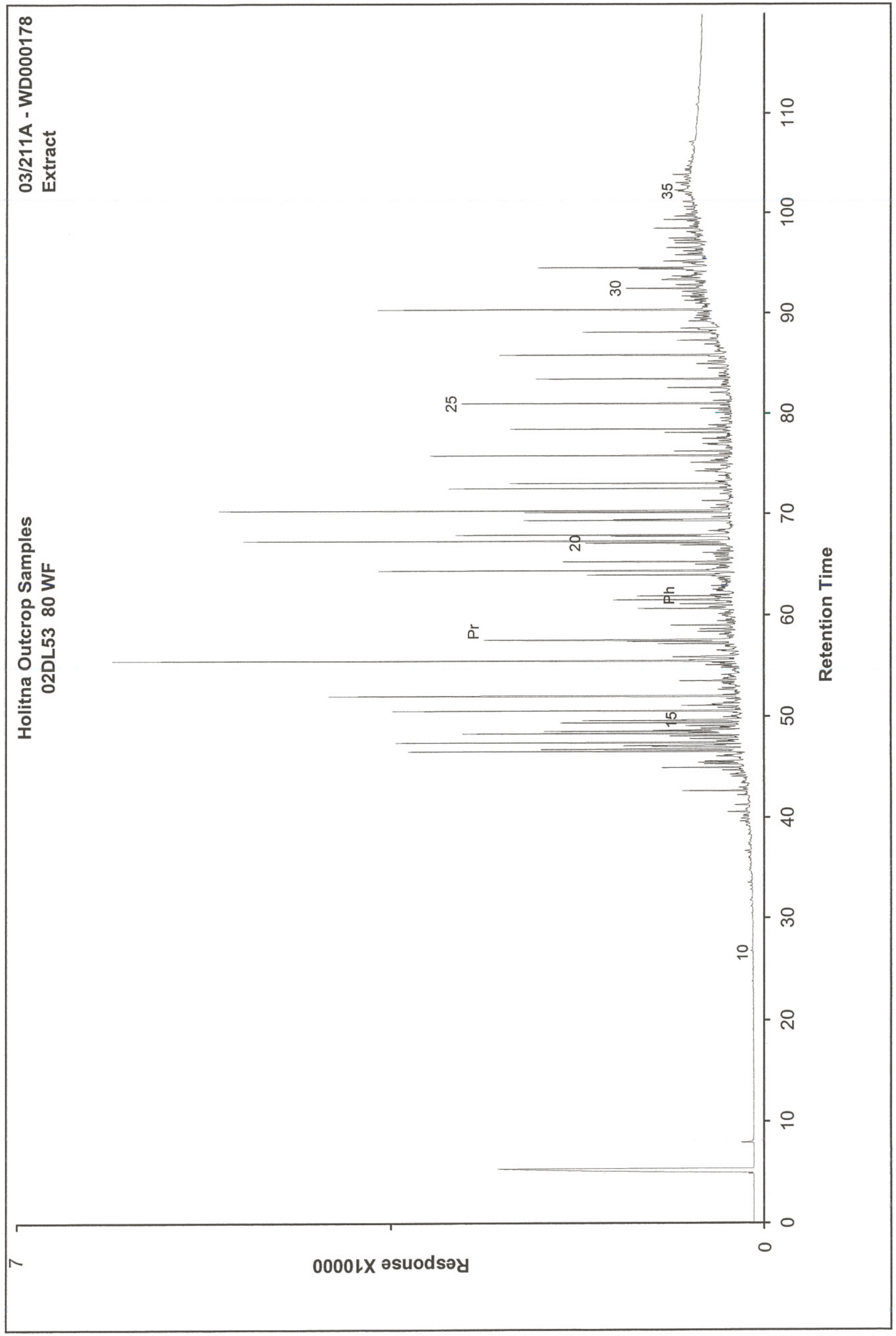




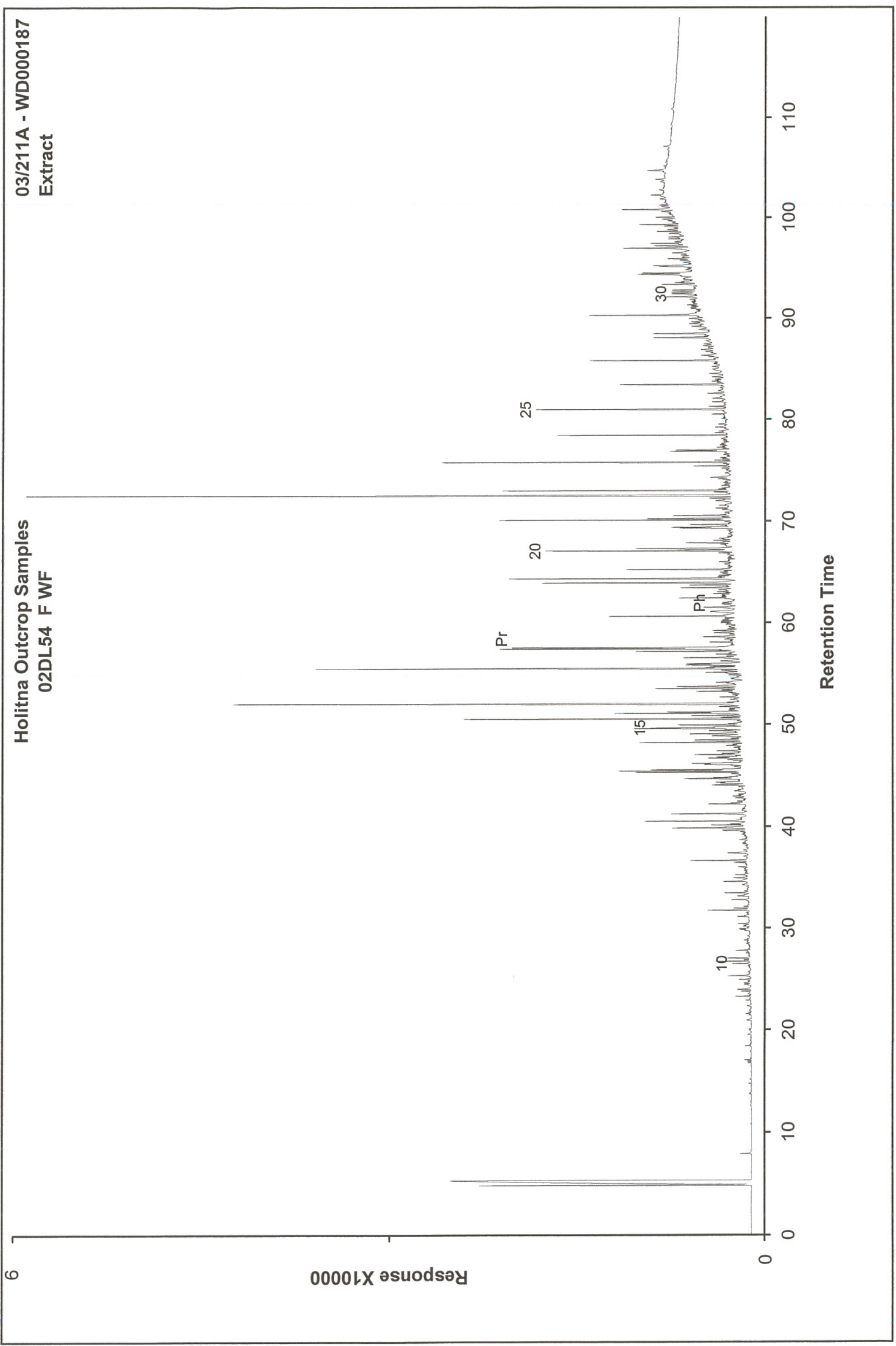

